\title{
A DAAM formin alcsalád szerepe az izomfejlődésben
}

\author{
Ph.D. értekezés
}

Készítette: Molnár Imre

Témavezető: Dr. Mihály József

Biológia Doktori Iskola

MTA Szegedi Biológiai Kutatóközpont

Genetikai Intézet

SZTE Természettudományi és Informatikai Kar

Szeged, 2014. 


\section{Tartalomjegyzék}

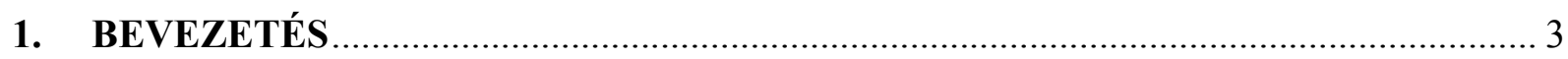

1.1. A harántcsíkolt izom általános felépítése ............................................................ 3

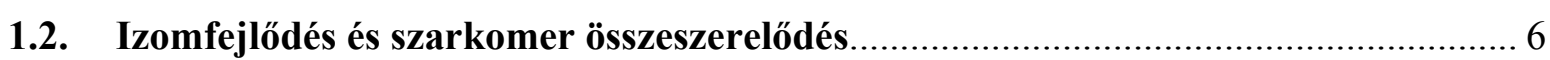

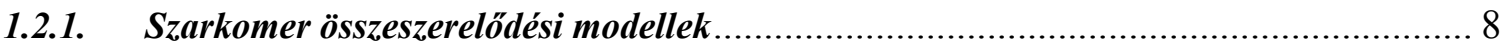

1.3. A miofilamentumok összeszerelődése …............................................................... 12

1.3.1. A vastag (miozin) filamentumok kialakulása ......................................................... 13

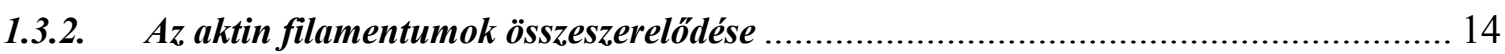

1.4. Aktin összeszerelődés és filamentumhossz szabályozás a harántcsíkolt izmokban 25

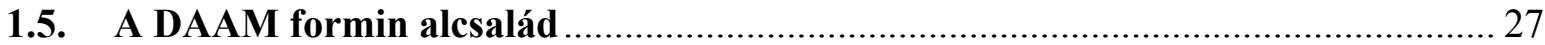

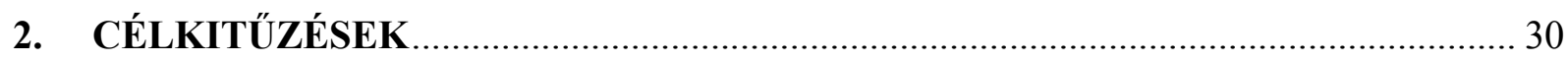

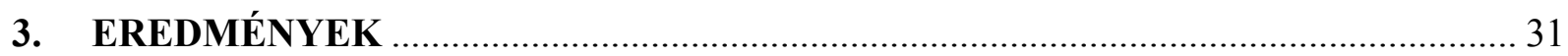

3.1. A dDAAM mutáns izmok fenotípusa és élettani jellemzése …............................. 31

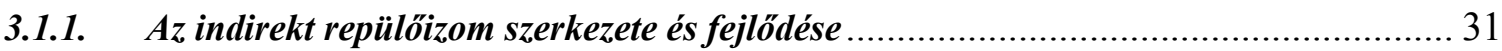

3.1.2. A dDAAM-nak az izomfejlödésben betöltött szerepét vizsgáló kísérletek elözményei .... 34

3.1.3. A dDAAM mutáció befolyásolja a röpképességet és az indirekt repülöizom fejlödését .. 37

3.1.4. Atomerö-mikroszkópiás mérések az indirekt repülöizom miofibrillumain.................... 40

3.1.5. A dDAAM hatással van a lárvális szomatikus izmok és a szívcsö fejlödésére ............... 41

3.2. A dDAAM hiányos miofibrillumok vizsgálata ................................................... 51

3.2.1. A dDAAM hiányos IFM szarkomerikus fenotípusa ................................................. 51

3.2.2. A dDAAM mutánsok elektronmikroszópos (EM) analizise ...................................... 53

3.3. A dDAAM fehérje szarkomerikus lokalizációja ................................................ 56

3.4. A dDAAM fehérje kölcsönhat a vékony filamentum mutánsokkal......................... 59

3.5. A dDAAM fehérje szükséges a vékony filamentumok növekedéséhez.................... 61

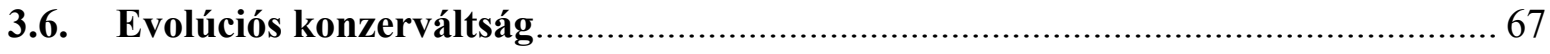

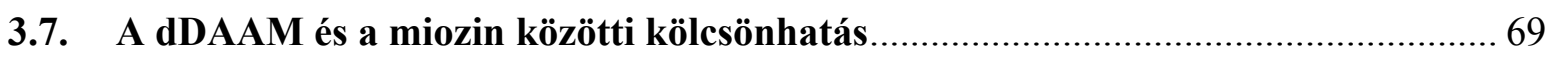

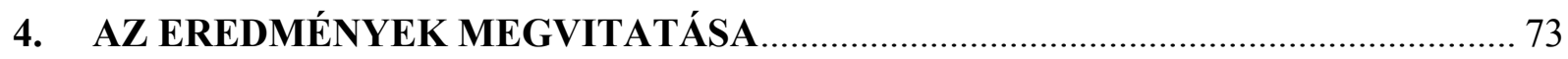

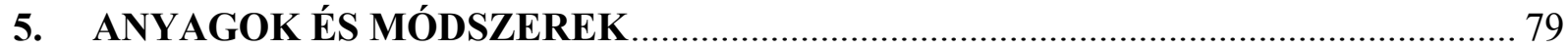

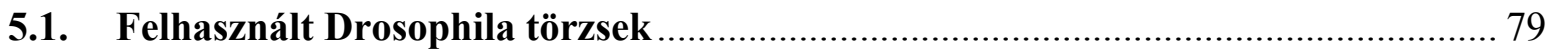

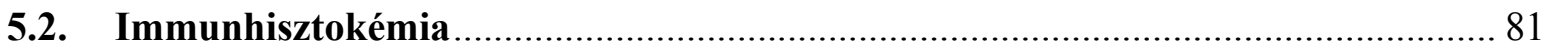

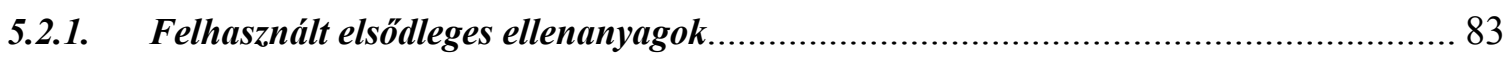

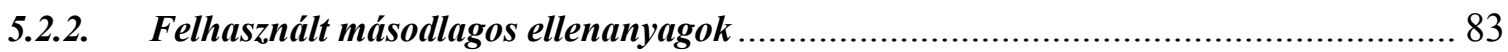


5.2.3. Felhasznált egyéb reagensek

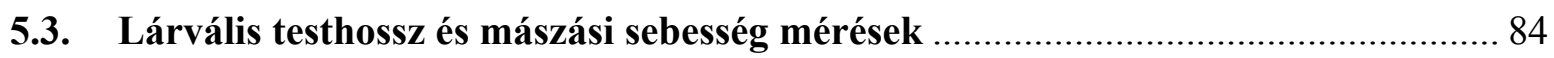

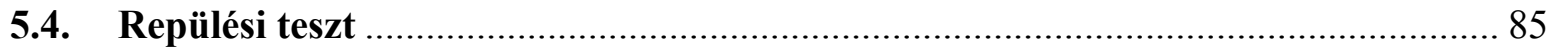

5.5. Sejtkultúrák és egér izom preparátumok előkészítése ….................................. 85

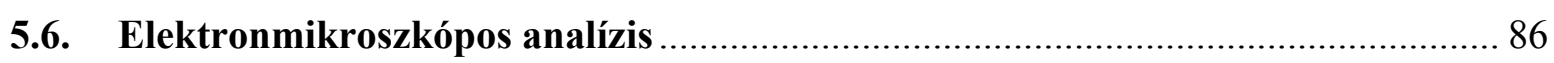

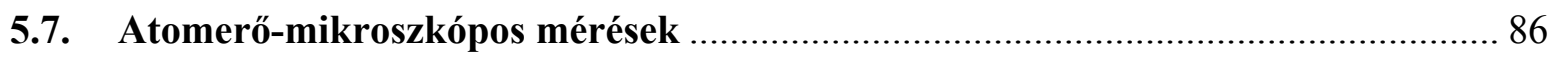

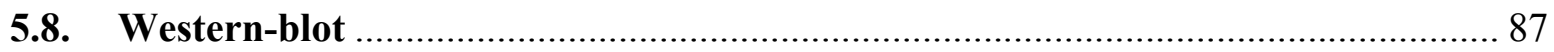

5.9. Az aktin filamentumok vég-vég kapcsolódásának vizsgálata .............................. 87

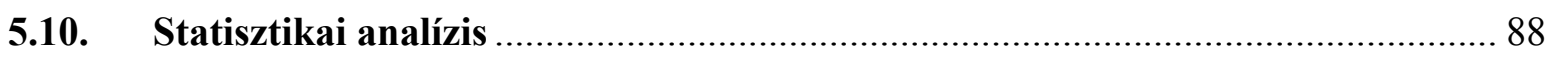

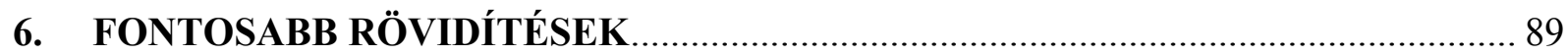

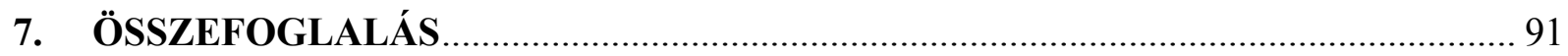

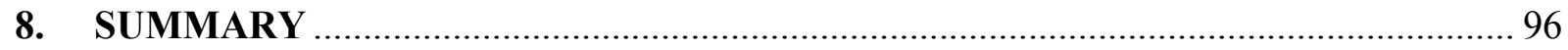

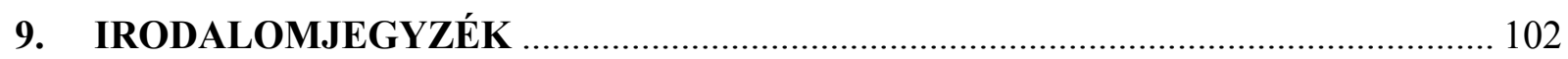




\section{BEVEZETÉS}

\subsection{A harántcsíkolt izom általános felépítése}

A harántcsíkolt izomban három fö szerveződési szintet lehet megkülönböztetni: az izomrostok, a miofibrillumok, és a miofilamentumok szintjét. Az izomrostok a mioblasztok összeolvadásából létrejött úgynevezett szincíciumok. Citoplazmájuk nagy részét a kontraktilis állomány tölti ki, ami több száztól több ezerig terjedő párhuzamosan futó miofibrillumból áll.

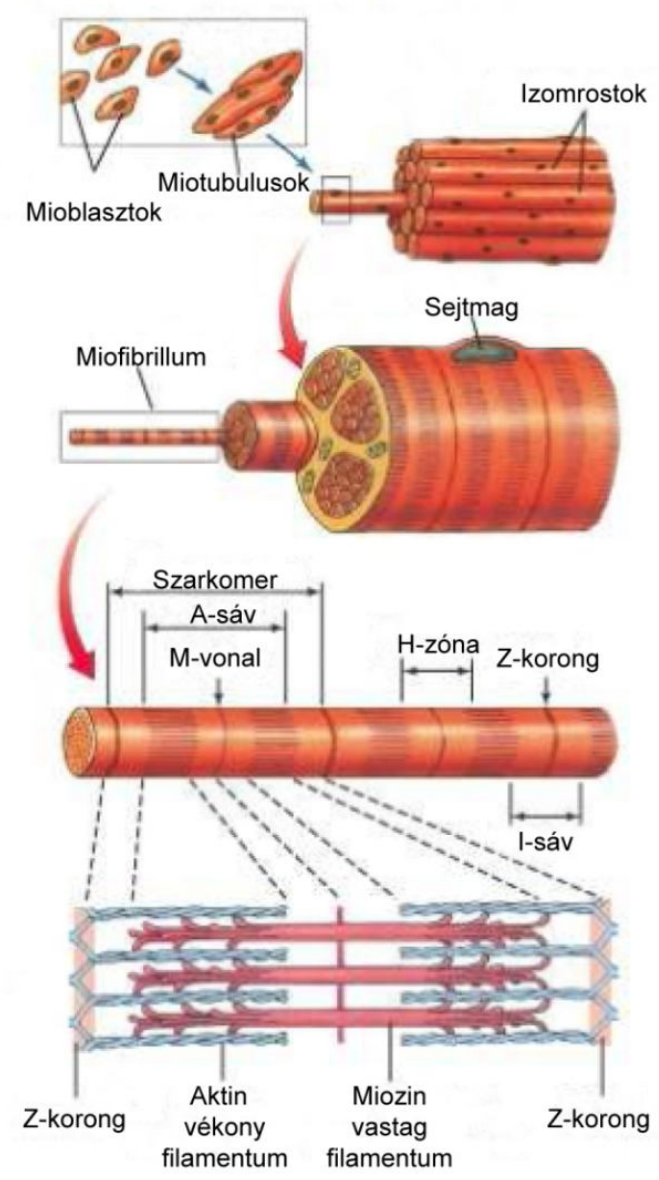

1. ábra A harántcsíkolt izom felépítése. A harántcsíkolt izom fö szerveződési szintjei: az izomrostok, a miofibrillumok, és a miofilamentumok szintje. A két Zkorong közé eső rész a szarkomer, az izom szerkezeti és müködési egysége. Forrás: Eckert, Animal Physiology 2002.

A miofibrillumok harántcsíkolt mintázata a szarkomerikus fehérjék rendkívül szabályos elhelyezkedésének tulajdonítható; fénymikroszkópos szerkezetük alapján osztották fel őket A- és I- sávokra. Az elnevezés onnan ered, hogy ha mikroszkópban az izmot polarizált fénnyel világították meg, akkor az „I” az izotróp, világos, míg az „A” az anizotróp, sötét sávnak mutatkozott. Elektronmikroszkóppal 
tovább vizsgálva, a világos I-sávok közepén sötét vonalak formájában található a Z-korong (az izom hisztológiában alkalmazott elnevezés szerint a „Z” a német „Zwischenscheibe” - az I-sávok közötti korong - elnevezésre utal). Míg az anizotróp, sötét sáv közepén egy újabb világos H-sáv (a német „Helle” - világos - elnevezés után), és az M-vonal (a német „Mittel” - közép elnevezés itt a szarkomer közepére utal), található (1. ábra). A miofibrillumok miofilamentumok kötegeiből állnak, amelyeket a szarkoplazmás retikulum ciszternái, mitokondriumok és glikogénszemcsék vesznek körül. A miofilamentumokat magasan szerveződött makromolekuláris komplexek alkotják, amelyek fó alkotóelemei a miozin II-t tartalmazó vastag filamentumok, és az aktint tartalmazó vékony filamentumok. Az A-sávnak megfelelő részt foglalják el a vastag filamentumok, míg az I-sáv adja azt a régiót, ahol a vékony filamentumok nem fednek át a vastag filamentumokkal. A két Z-korong közé eső rész a szarkomer, az izom szerkezeti és müködési egysége. A szarkomer közepén az M-vonal fehérjék keresztkötik és kihorgonyozzák egymáshoz a vastag filamentumokat (1. ábra, 2. ábra).

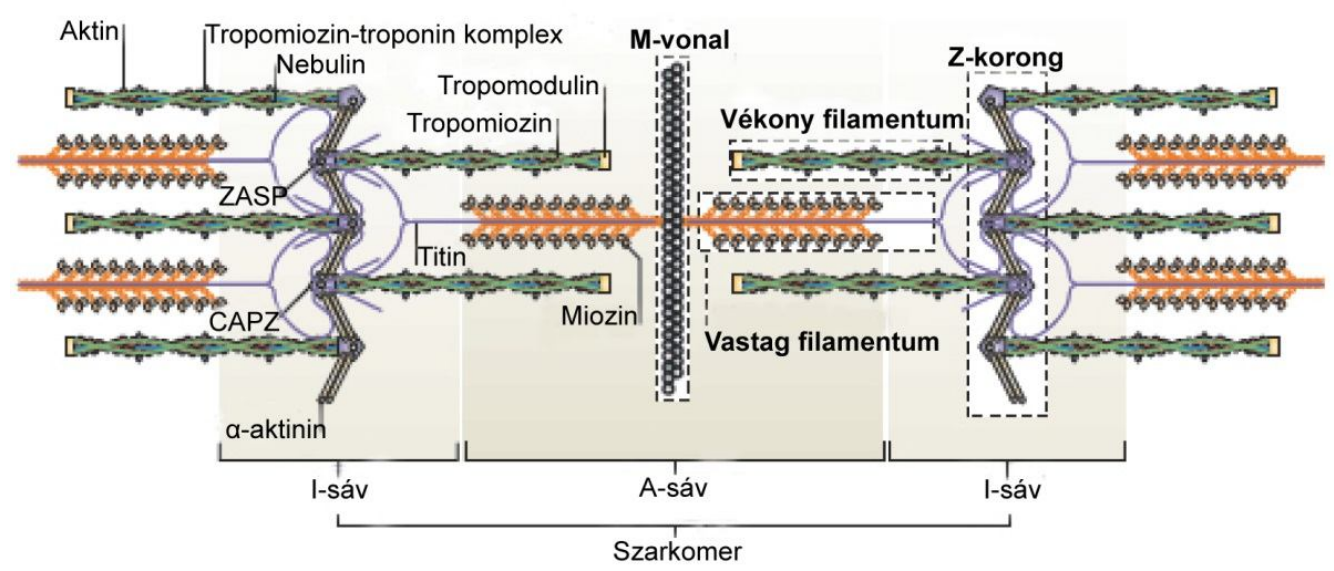

2. ábra A szarkomer szerkezete. Az ábrán nagyobb felbontásban látható az előbbi képen ábrázolt szarkomer. Az ellentétes polaritású vékony filamentumokat az $\alpha$-aktinin keresztköti és rögzíti a Z-korongok mindkét oldalához. A vékony filamentumok F-aktinból és a hozzájuk kapcsolódó Tropomiozin-Troponin komplexből állnak. Gerincesek esetében a vékony filamentumok Nebulint is tartalmaznak, amely a filamentumok hosszát szabályozza. A vékony filamentumok plusz végét a CAPZ míg mínusz végét a Tropomodulin fehérje zárja le. A ZASP fehérje a Zkorongok szerveződésében játszik szerepet. A vastag fillamentumokat az M-vonal fehérjék rögzítik. A gerincesekben a Titin molekulák az M-vonaltól a Z-korongokig terjednek. A vastag filamentumokat rögzítik, és elasztikus rendszert alkotva megakadályozzák a miofilamentumok túlzott megnyúlását. Forrás: Sparrow és Schöck 2009. 
A vastag filamentum néhány száz miozin II molekulát tartalmaz antiparallel elrendezésben, vagyis az ellentétes irányú miozin molekulák farki részei a Miomezin fehérje segítségével összekapcsolódnak. A miozin molekula két motorikus nehéz láncból (MHC) áll, végükön található a “fej”-régió. Ily módon bipoláris szerkezetet vesznek fel, amelyben a fejek oldalirányban állnak. A fejhez két pár (fajspecifikus) könnyü lánc (MLC) kapcsolódik. A könnyü lánc párok közül az egyik mindig az eszenciális könnyű lánc (ELC), a másik a regulációs könnyü lánc (RLC).

A vékony filamentumokat a globuláris szerkezetű aktin monomerek (G-aktin) polimerizálódásával keletkező kettős hélix szerkezetű filamentáris aktin (F-aktin) (Chesarone and Goode, 2009) és a Tropomiozin-Troponin komplex alkotja. Az F-aktin hélixhez kapcsolódnak a Tropomiozin dimerek, melyek szintén helikális szerkezetet vesznek fel, a 38 nm hosszú hélixük hét aktin monomernyi távolságon ível keresztül. A dimerek végei szorosan egymáshoz kapcsolódnak, így a Tropomiozin ív az aktin filamentum mentén folyamatos. A Tropomiozin molekulákon keresztül kötődik az aktin filamentumokhoz a három alegységből álló Troponin komplex. Ezekből a Troponin-T alegység (TnT) a Tropomiozinhoz kötődik, a Troponin-C (TnC) kalcium-ionokat köt, végül a Troponin-I (Tn-I) az aktin-miozin kapcsolódást gátolja (Au 2004; Gunning 2008) (3. ábra). A vékony filamentumok párhuzamos sorokba rendezve rögzülnek a Z-korongokhoz, amit az $\alpha$-aktinin fehérje keresztkötő aktivitása biztosít. Gerincesekben a harántcsíkolt izmok vékony filamentumai még egy járulékos fehérjét tartalmaznak, a Nebulint. Ez egy hosszú, fonál-alakú, rugalmatlan fehérje, amely az aktinfilamentumokkal párhuzamos lefutású, azokat a Z-korongokhoz rögzíti, és valószínűleg részt vesz a vékony filamentumok hosszának szabályozásában (Bang és mtsai. 2006; Witt és mtsai 2006). 


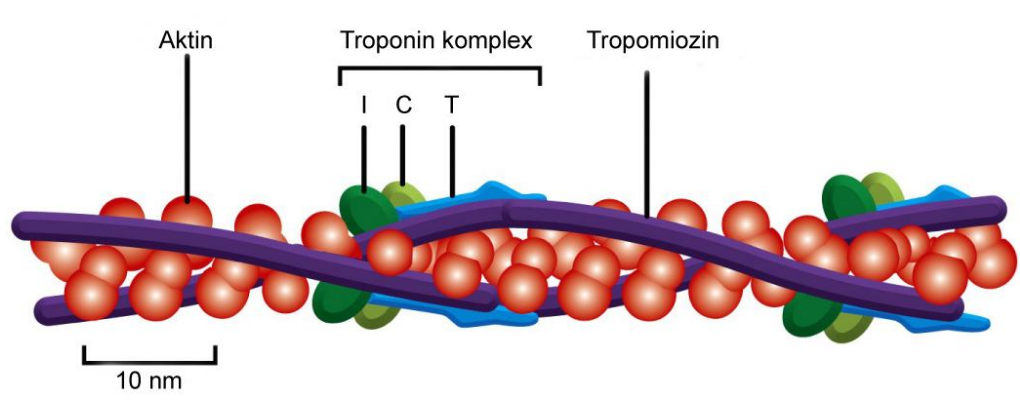

3. ábra A vékony filamentumok szerkezete. Az F-aktin hélixhez kapcsolódnak a Tropomiozin dimerek. Mivel a dimerek végei szorosan egymáshoz kapcsolódnak, így a Tropomiozin ív az aktin filamentum mentén folyamatos. Ezen a Tropomiozin íven keresztül pedig a három alegységböl álló Troponin komplex kötödik az aktin filamentumokhoz. Forrás: Alberts és mtsai. 2002.

A miofibrilláris vastag és vékony filamentumok egymáshoz viszonyított szarkomerikus helyzete szigorúan szabályozott. Rovarok repülőizmaiban például egy-egy miozin filamentumot hat vékony filamentum vesz körül hexagonális elrendezésben. A vastag filamentumok miozin II fehérjéinek globuláris feji része képes a vékony filamentumok F-aktinjához kötődni, ami az izomösszehúzódás alapjául szolgál, hiszen az aktomiozin kölcsönhatás eredményeként az egymáson elcsúszó két filamentum rendszer a szarkomerek megrövidülését okozza (Lymn és Taylor 1971). Az aktin és miozin fehérjék kapcsolódását, tehát végső soron az izomösszehúzódást, a Tropomiozin-Troponin komplex szabályozza.

A vékony és vastag filamentumok mellett a miofibrillumok harmadik fö filamentum rendszerét a Titin filamentumok alkotják. A Titin óriásmolekula a Z-korongtól az M-vonalig terjed és ily módon egymáshoz rögzíti a szarkomer széli és központi szerkezeti elemeit. A Titin filamentumok egy masszív elasztikus rendszert alkotnak, aminek az a legfontosabb szerepe, hogy megakadályozza a miofilamentumok túlzott megnyúlását (2. ábra) (Clark és mtsai. 2002).

\subsection{Izomfejlődés és szarkomer összeszerelődés}

Az izomfejlődés egy többlépéses folyamat, amely bizonyos sejteknek izom prekurzor sejtekké vagy mioblasztokká válásával kezdődik. A paraxiális myotomban és a dermomyotomban bizonyos mioblaszt őssejtekben a pax-3 gén kezd aktiválódni és magas szinten kifejeződni, amit a miogenezis szabályozó gének, a bHLH (basic helix-loop-helix) 
fehérjecsaládba tartozó transzkripciós faktorok expressziója követ (Brand-Saberi 2005). A bHLH faktorokat termelő sejtek már mioblasztok, melyek az izomszövetté differenciálódás irányába indultak. Ezek egy aktív osztódási fázison mennek keresztül, ahol a számuk megsokszorozódik. Ezt követően vándorolnak és sorokba rendeződnek, majd fuzionálva többsejtmagvú, szincíciális miotubulusokokat hoznak létre vagy közvetlenül kardiomiocitákká differenciálódnak. Ezután az extracelluláris mátrixhoz (ECM) vagy más izomsejtekhez kapcsolódnak mielött miofibrillumokat képeznének. A miofibrillogenezis kezdeti szakaszában egy szarkomerekből álló sor jön létre. Ezek a szarkomerek később szélességükben, bizonyos izmokban hosszúságukban is növekednek, és szorosan kapcsolódnak egymáshoz, vagy esetenként a szarkolemmához. A képződő miofibrillumok fokozatosan kitöltik a sejt belsejét, egymáshoz és a miocita sejtorganellumokhoz Dezmin gazdag intermedier filamentumokon keresztül kapcsolódnak addig, amíg az összes rendelkezésre álló helyet el nem foglalják, csak keskeny részeket hagyva a szarkoplazmatikus retikulum, a mitokondriumok és a sejtmagok számára. További mioblasztok egyesülnek a miotubulusok növekvő végeivel addig, amíg a soksejtmagvú szincícium egy érett, teljesen differenciálódott izomrosttá nem válik (Sanger és mtsai. 2010), amelyben felnőtt miozin izoformák helyettesítik az embrionális, korai izoformákat (Rosser és mtsai. 1998; Agbulut és mtsai. 2003).

Az izomrostok végei a vázrendszerhez az izom-ín átmeneten keresztül csatlakoznak, vagy a szívizom esetében egy hálózatos membránrendszeren (intercalated discs) keresztül kapcsolódnak szorosan egymáshoz. A heterodimerikus Integrinek, amelyek a vékony filamentumokat az ECM-hez kapcsolják, a fó strukturális és funkcionális komponensei az izomín átmeneteknek. A periferiális miofibrillumok a Z-korongok szintjén oldalirányban is ki vannak 
horgonyozva az ECM-hez, a gerincesekben és a gerinctelenekben egyaránt (Moerman és Williams 2006; Hudson és mtsai. 2008; Pardo és mtsai. 1983) (4. ábra).

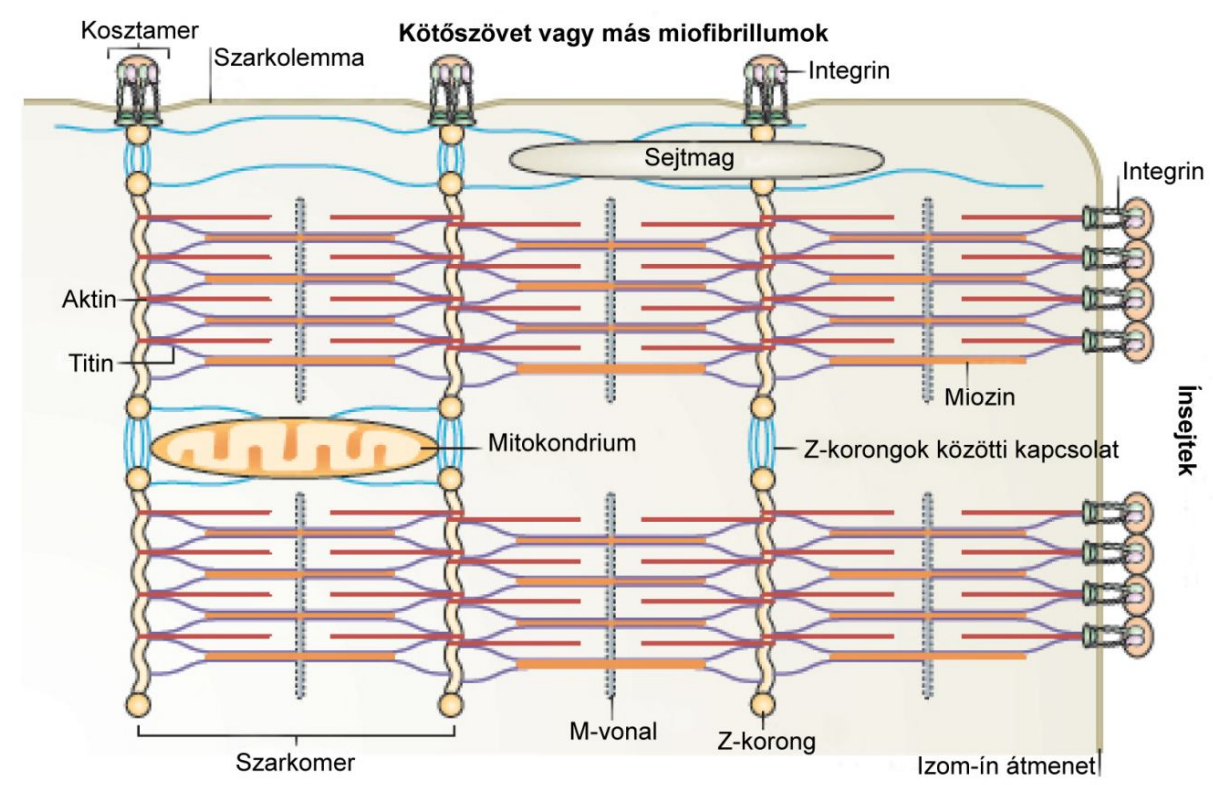

4. ábra A harántcsíkolt izomrost vázlatos áttekintése. Egy harántcsíkolt izomrost szagittális metszeti képe, amely két miofibrillumot, a közöttük levő kapcsolódást és a szarkolemmát ábrázolja. Csak a fő szarkomerikus alkotóelemek - az aktin, a miozin és a Titin - lettek feltüntetve. A gerincesek esetében, a miofibrillumok egymáshoz és a kosztamerekhez intermedier filamentum fehérjék (világoskékkel jelölve) és más citoszkeletális fehérjék (sárga körökkel jelölve) segítségével kötődnek. Az izom-ín átmenetek szintjén, a transzmembrán Integrinek a miofibrillumokat adapter fehérjéken (zöld oválisokkal jelölve) keresztül rögzítik az ín mátrixhoz (narancs oválisokkal jelölve). A kosztamerek a Z-korongokat kapcsolják a környező kötőszövethez vagy más miofibrillumokhoz. Forrás: Sparrow és Schöck 2009.

Ezeket az adhéziós helyeket nevezik kosztamereknek, és ezek az izom-ín átmenetekhez hasonlóan egy sor olyan alkotóelemből állnak, mint a fokális adhéziók a nem-izom sejtek esetében (Pardo és mtsai. 1983; Ervasti és mtsai.2003; Quach és mtsai. 2006) (4. ábra).

\subsubsection{Szarkomer összeszerelödési modellek}

Az izom differenciációt érintő fontos kérdés, hogy a harántcsíkolt izomsejt hogyan képes egy ilyen szabályosan ismétlődő, szigorúan rendezett szarkomerekből álló szerkezetet létrehozni a miofibrillogenezis során, más szóval, hogyan zajlik a szarkomer összeszerelődés? Ezzel kapcsolatban többféle elképzelés létezik, a legfontosabbak közülük: a független összeszerelődési-, a „titin mint szarkomerikus váz”- és a premiofibrillum modell. Az alábbiakban 
ezeket foglalom röviden össze, szem elött tartva azt a tényt, hogy az itt felsorolt elképzelések a különböző modellszervezetek vad típusú és mutáns szarkomerikus struktúráinak megfigyelése alapján születtek, és ha a szarkomerogenezis folyamatának egészét tekintjük, a felsorolt modelleknek nem feltétlenül kell kizárniuk egymást.

A független összeszerelödési modell alapja, hogy a miofibrillogenezis kezdeti lépései során bipoláris miozin filamentumok és úgynevezett I-Z-I komplexek szerelődnek össze egymástól függetlenül (Holtzer és mtsai. 1997), amelyek aztán később integrálódnak a jól ismert szarkomerikus szerkezetekbe. Az I-Z-I komplexek ellentétes irányítottságú vékony filamentumokból és az azokat egyesítő Z-korong kezdeményből álló struktúrák, amelyek elektronmikroszkópos felvételeken sürü $\alpha$-aktinin nyalábokként jelennek meg, amelyekből aktin filamentumok ágaznak szét. A fő megfigyelés, ami ezt az elméletet alátámasztja az, hogy aktin hiányában a szarkoplazmában szabadon sodródó A-sáv struktúrák láthatók, míg a miozin hiányos izmokban vékony filamentumokkal összekapcsolódott szabálytalan szerveződésű Z-korongok
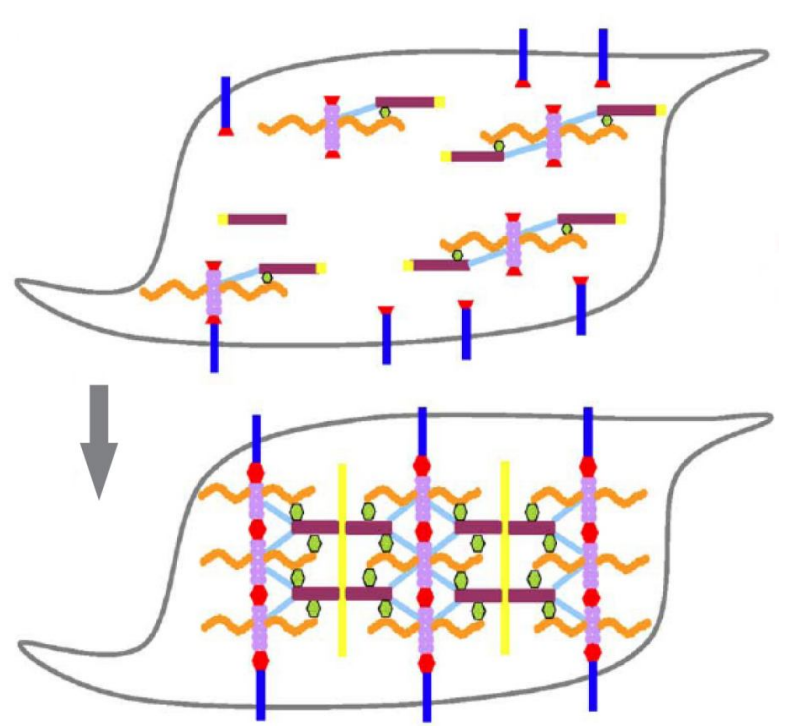

Integrin Vastag filamentum

Feszültség szenzor

- TM-Troponin komplex

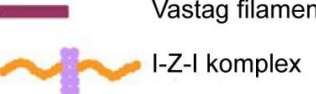

Titin találhatók (Holtzer és mtsai. 1997; Lin és mtsai. 1994) (5. ábra).

\section{5. ábra A független szarkomer összeszerelódési} modell. A szarkomerek kialakulását megelőzően, a különböző komplexek, az Integrineket, a feszültség szenzorokat, az I-Z-I komplexeket, a vastag filamentumokat és a Tropomiozin-Troponin komplexeket is beleértve, egymástól függetlenül szerelődnek össze. Ezt követően az Integrin fehérjékkel kölcsönhatva hozzák létre a szigorúan rendezett szarkomer szerkezetet. Ezen komplexek bármelyikének az eltávolítása az egész szerkezet összeomlását vonja maga után. Forrás: Rui és mtsai. 2010. 
A „Titin mint szarkomerikus váz" modell azon alapszik, hogy a szarkomer összeszerelődés vázát a Titin óriásmolekula adja. Mivel ismert, hogy az aktin és a Titin filamentumok már jóval a vastag filamentumok kialakulása előtt megjelennek, felmerült az a lehetőség, hogy az M-vonal és a Z-korongok egymáshoz viszonyított végső távolsága a Titin óriásmolekulától függ, amely szarkomerikus vázként is szolgálhat a két másik miofilamentum rendszer számára. Az óriás fehérjelánc növekedése során képződő új fehérje domének további vastag filamentum és M-vonal alkotóelemeket gyüjtenek maguk köré, és ahogy a Titin fehérje kialakítja végső konformációját, a C-terminális régiója mellett az M-vonal végső struktúrája is létrejön (Ehler és Gautel 2008). A Titin fehérje C-terminális irányból csonkolt formáinak az összehasonlításából az derült ki, hogy a csonkolás mértékével arányosan károsodik a vastag filamentumok és a szarkomerek szerveződése (Miller és mtsai 2003).

A miofibrillum képződésre vonatkozó elképzelések harmadik csoportját a „premiofibrillum" alapú modell alkotja. Ez a differenciálódó csirke kardiomiocita sejttenyészetek tanulmányozásán alapuló modell azt javasolja, hogy a miofibrillogenezis során először de novo módon úgynevezett premiofibrillumok képződnek a sejthártya közelében (Heuson-Stiennon 1965; Kelly 1969), amelyek főként aktinból és aktin asszociált fehérjékből (Tropomiozin/Troponin komplex, $\alpha$-aktinin), illetve nem-izom miozinokból (NMM) állnak. A premiofibrillumok aktin stressz-filamentumokra emlékeztető struktúrák, amelyek szabálytalan periodicitású $\alpha$-aktinin és nem-izom miozin felhalmozódást mutatnak. Később ezekből lesznek az érett miofibrillumok, ahol az érés során a nem-izom miozin izom típusú miozinnal helyettesítődik (Rhee és mtsai. 1994; LoRusso és mtsai. 1997) (6. ábra). 


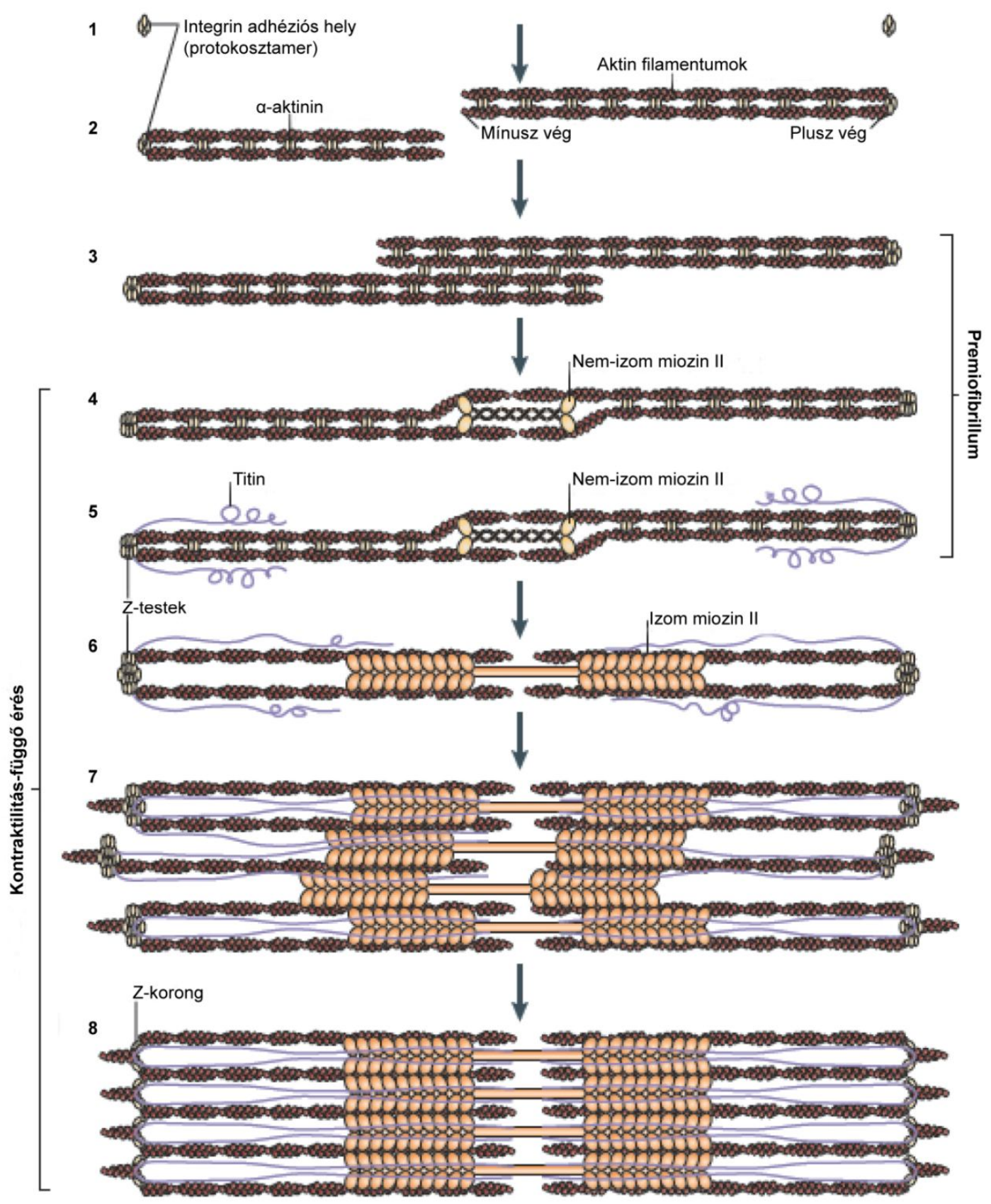

6. ábra A premiofibrillum modell. A protokosztamerek, amelyek az izomsejt mentén véletlenszerüen helyezkednek el, aktin filamentumokat polimerizálnak (1-2. lépés) (Az egyszerüség kedvéért adhéziós helyenként csak két aktin filamentum van ábrázolva). Az ellentétes polaritású és egymással átfedő aktin filamentumokat az $\alpha$ aktinin keresztköti (3. lépés). Az oldalirányból fuzionált antiparallel aktin filamentumok nem-izom miozin II-t építenek be, amely kiszorítja az $\alpha$-aktinint (4. lépés). A nem-izom miozin II bipoláris filamentumok száma a stresszrostokban levő aktin filamentumok számától függ. A protokosztamerek Titint és még több $\alpha$-aktinint gyüjtenek maguk köré, aminek eredményeként kialakulnak a Z-testek (5. lépés). A következőkben az izom típusú miozin II beépülése történik meg, valószínüleg a Titin segítségével (6. lépés). A kontraktilitás-függő érési folyamat során a Z-testek hosszanti irányban egymáshoz igazodnak (7. lépés). Ezek után a Z-testek oldalirányban Zkorongokká egyesülnek (8. lépés). Forrás: Sparrow és Schöck 2009. 
Ez a modell összhangban van azokkal az elektronmikroszkópos vizsgálatokkal, amelyek során megfigyelték, hogy a Z-korongok először mint kisméretű membrán asszociált aggregátumok jelennek meg. Ezek a már említett, Z-testeknek nevezett kezdemények később növekedésnek indulnak, oldalirányban fuzionálnak egymással, így alakítva ki az érett Zkorongokat (Heuson-Stiennon 1965). Immunofluoreszcens és elektronmikroszkópos felvételek azt mutatták, hogy a Z-testek, az $\alpha$-aktinin és a Titin (a két legkorábbi Z-korong marker) felhalmozódásának helyei, ezzel bizonyítva, hogy a Z-testek valóban a Z-korongok elődjeinek tekinthetők (Tokuyasu 1989). Összességében a jelenleg ismert kísérleti adatok fényében a premiofibrillum elmélet a legáltalánosabban elfogadott nézet a miofibrillumok összeszerelődésére.

\subsection{A miofilamentumok összeszerelődése}

Az eddig összefoglaltak alapján nyilvánvalónak látszik, hogy a miofibrillogenezis sok lépésből álló, bonyolult folyamat, mindamellett ennek a folyamatnak kitüntetett része a miozin és aktin filamentumok összeszerelödése. Jól ismert, hogy in vitro körülmények között mind a miozin, mind az aktin képes polimerizálódni és olyan filamentáris struktúrákat létrehozni, amelyek hasonlóak a vastag filamentumokhoz (Niederman és Pollard 1975) és a vékony filamentumok F-aktinjához (Cooper és mtsai. 1983). Azt is tudjuk azonban, hogy in vivo körülmények között ezek a folyamatok szigorúan szabályozottan zajlanak és -főként az aktin esetében- számos járulékos fehérje részvételével történnek. Az alábbi fejezetekben a miofilamentumok, különösen az aktin filamentumok kialakulására vonatkozó ismereteket foglalom össze. 


\subsubsection{A vastag (miozin) filamentumok kialakulása}

A nem-izom miozin II-ről tudjuk, hogy képes önállóan összeszerelődni rövid bipoláris minifilamentumokba, amelyek a kortikális sejtvázban és a stressz-rostokban fordulnak elő (Scholey és mtsai. 1980). Ezzel a „spontán” összeszerelődési képességgel valószínűleg az izom miozin II is rendelkezik, legalábbis mind ez idáig nem azonosítottak olyan fehérjét, ami specifikusan elősegítené a miozin molekulák polimerizációját. Viszont nemrég kimutatták, hogy az izom típusú miozin II globuláris fej régiójának feltekeredéséhez (foldingjához), illetve a magasabb szervezettségü szarkomerikus vastag filamentumok összeszerelődéséhez nélkülözhetetlenek az izom specifikus molekuláris chaperonok (Kim és mtsai. 2008; Chow és mtsai. 2002). A miozin II nem képes a motorfehérje funkcióját megtartani, ha in vitro körülmények között vagy bakteriális rendszerekben expresszáltatják (Chow és mtsai. 2002; Levitsky és mtsai. 1990), ami a chaperonok segítségével megvalósuló fehérje folding fontosságát bizonyítja. Ebben az összefüggésben „chaperon”-nak tekintünk minden olyan faktort, amely közvetlenül érintett a fehérje folding és stabilitás megteremtésében, függetlenül a fehérje aggregációt megelőző szerepétől. A miozin II megfelelő foldingját olyan hősokk fehérjék végzik, mint a Hsp90, a Hsp70, és az Unc45 (Liu és mtsai. 2008b; Srikakulam és Winkelmann 2004; Willis és mtsai. 2009). Gerincesekben a Hsp90 fehérjecsaládnak két izoformája ismeretes (a Hsp90a1 és a Hsp90a2), amelyek a vastag filamentumok megfelelő kialakulásához szükségesek. Ezek a chaperonok specifikusan a fejlődő szív és vázizomzatban fejeződnek ki (Krone és mtsai. 2003; Etard és mtsai. 2007), míg más izoformák expressziója sokkal általánosabb jellegü (Thisse és mtsai. 2004). Habár az izom specifikus chaperonok lokalizációja az érett miofibrillumokban a Z-korongok szintjére korlátozódik, izom károsodás során áthelyeződnek az A-sávba, oda ahol az újból keletkező miozin filamentumok összeszerelődése történik (Etard és mtsai. 2008). Az ezeket 
a chaperonokat kódoló gének mutációi gyakran társulnak különböző izomszintü megbetegedésekkel, miopátiákkal (Vogel és mtsai. 2009), ami arra utal, hogy a citoszkeletális váz épsége elengedhetetlen a funkcionális miozin motorfehérjék későbbi összeszerelődéséhez.

\subsubsection{Az aktin filamentumok összeszerelödése}

Az F-aktint felépítő aktin monomerek eredendő polaritásából adódóan az aktin filamentumok szerkezetileg polarizáltak (7. ábra). In vitro körülmények között, kellöen magas aktin monomer koncentráció mellett a G-aktinból spontán polimerizációval F-aktin képződik. Az így kialakuló filamentumok mindkét végén történhet monomer addíció és disszociáció is, azonban az úgynevezett szöges (plusz) végen kb. 7-8-szor nagyobb az addíció sebessége, mint a hegyes (mínusz) végen.

A

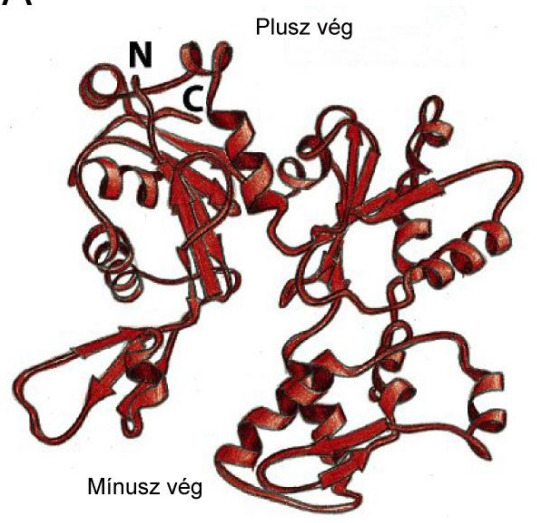

$B$

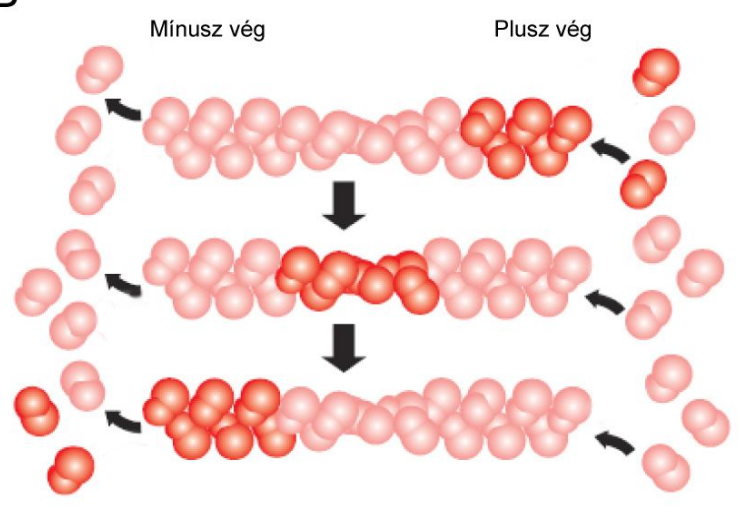

7. ábra Az aktin filamentumok „taposómalom” modellje. Az (A) panelen látható a monomer aszimmetrikus, polarizált szerkezete, aminek következtében a filamentumok is szerkezetileg polarizáltak. (B) Ez a sematikus modell szemlélteti, hogy az aktin filamentumnak ebben az egyensúlyi állapotában az alegységek beépülési aránya a plusz végen megegyezik a mínusz végen zajló depolimerizáció arányával. Ennek következtében a polimer képes egy állandó hossz megtartására, annak ellenére, hogy az őt felépítő alegységek állandó áramlásban vannak. Forrás: Alberts és mtsai. 2002.

In vivo körülmények között egy még nyilvánvalóbb kinetikai polarizáltság jellemző az aktin filamentumokra, amit az úgynevezett „taposómalom” (treadmilling) modellel jellemeznek. Ennek az a lényege, hogy sejtekben monomer addíció kizárólag a filamentumok plusz végén történik, míg a hegyes vég a monomerek disszociációjának, a filamentum depolimerizálódásának 
a helye (7. ábra). Az aktin filamentumok kialakulásának kritikus első lépése az aktin nukleáció, amelynek során néhány aktin monomer egyesül, hogy egy nukleációs magot, azaz egy olyan 3-4 monomerből álló filamentum kezdeményt hozzon létre, amely kiindulópontként szolgálhat a további polimerizáció számára. In vitro körülmények között a nukleációs magok kialakulását a magas G-aktin koncentráció biztosíthatja, a nukleációhoz szükséges koncentrációt kritikus koncentrációnak nevezzük. In vivo körülmények között azonban a szabad G-aktin koncentráció alacsonyabb, mint a kritikus koncentráció, ezért a spontán nukleáció kinetikailag gátolt és így a sejtek elkerülik az anarchikus filamentum képződést. Annak érdekében, hogy az aktin filamentumok képződése térben és időben szabályozott módon történjen, olyan fehérjék vannak jelen a sejtekben, amelyek képesek közvetlen módon elősegíteni az aktin nukleációs magok kialakulását. Ezeket a fehérjéket összefoglalóan aktin nukleációs vagy aktin összeszerelő faktoroknak nevezzük. Amennyiben egy nukleációs mag már kialakult, a filamentum növekedése in vivo is kinetikailag előnyössé válik, ám ilyenkor nem G-aktin, hanem annak ATP-vel és egy aktin momomer-kötő fehérjével, a Profilinnel alkotott komplexe épül be a növekvő filamentum plusz végén.

Irodalmi adatok alapján az eddig azonosított aktin nukleációs faktorokat molekuláris müködésmódjuk alapján három csoportba sorolhatjuk (Chesarone és Goode 2009). Az első csoport tagjai nukleációs magok strukturális imitálásával, a második csoport tagjai aktin monomerek megkötésével és nukleációs maggá való alakításával, végül a harmadik csoport tagjai a spontán kialakult polimerizációs intermedierek stabilizálásával hozzák létre a nukleációs magot. A három nagy csoportba viszonylag kisszámú fehérje tartozik: az Arp2/3 komplex az első, a WASP-Homológia 2 (WH2) domént tartalmazó fehérjék a második, míg a forminok a harmadik csoport tagjait alkotják (8. ábra A). Megjegyzendő, hogy a forminok nem csak 
nukleációs faktorként müködnek, hanem a növekvő filamentumok plusz végéhez kötődve elősegítik további aktin monomerek beépítését is, tehát elongációs szerepük is van (Pollard 2007; Goode és Eck 2007; Higgs 2005). Jelenlegi ismereteink szerint az Ena/Vasp fehérjék is elongációs faktorokként szerepelnek (Haffner és mtsai. 1995; Ahern-Djamali és mtsai. 1999) (8.

\section{ábra B).}

(A) Nukleációs faktorok
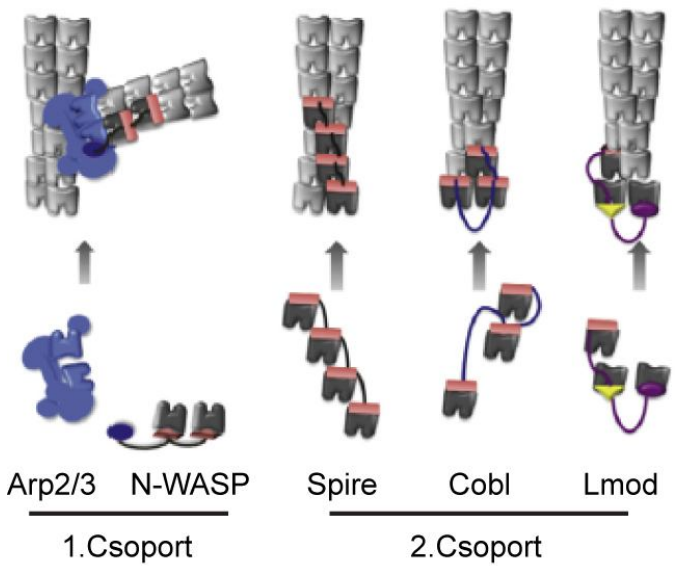

(B) Elongációs faktorok

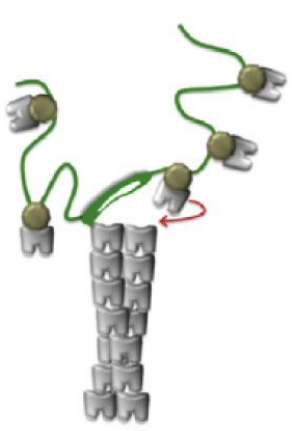

Forminok

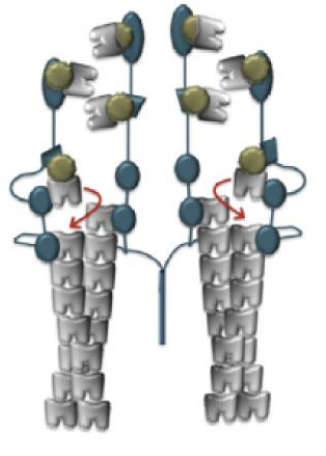

Ena/VASP
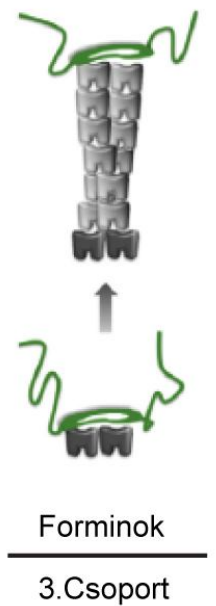

8. ábra Aktin nukleációs és elongációs faktorok. Az (A) panelen az említett három nukleációs faktor feltételezett müködési mechanizmusa látható. A nukleációban szerepet játszó domének különböző színekkel, azok az aktin alegységek, amelyek nukleációs magként szolgálnak, pedig feketével jelöltek. (B) A forminok és az Ena/Vasp fehérjecsalád befolyásolják az aktin filamentumok elongációját. Az Ena/VASP fehérjecsalád müködésmódja még nem teljesen ismert. Forrás: Chesarone és Goode 2009. 


\subsubsection{1. $\quad$ Az Arp2/3 komplex szerkezete és müködése}

Elsőként az Arp 2/3 (Actin-related protein) típusú fehérjék nukleációs aktivitását mutatták ki (Goley és Welch 2006). Ez egy 220 kDa-os fehérje komplex, amely hét, eukarióta szervezetekben magasan konzervált polipeptidláncból áll. Az Arp2 és Arp3 mellett ide tartoznak az ARPC1-ARPC5 alegységek is. Ez a komplex elágazó aktin filamentumokat alakít ki azáltal, hogy egy meglévő filamentum oldalához kapcsolódik, és ott egy újabb filamentum képződését indítja el, amely a kiindulási filamentummal $70^{\circ}$-os szöget fog bezárni. Az Arp2/3 komplex önmagában inaktív, aktiválódásához szükség van az Arp2 alegység treonin és tirozin aminosavainak a foszforilálására (LeClaire és mtsai. 2008) és bizonyos nukleációt elősegítő fehérjékkel (NPFs, Nucleation Promoting Factors) való kölcsönhatásra. A legtöbbet tanulmányozott NPF-ek a WASP/SCAR/WAVE és Cortactin fehérjecsaládokba tartozó fehérjék.

Ezek a faktorok olyan konformációs változásokat idéznek elő az Arp2/3 komplexben, amelyek az Arp2 és Arp3 alegységeket közelebb hozzák egymáshoz, így imitálva egy aktin dimer szerkezetét. Emellett, az NPF-ek a WH2 doménjeiken keresztül egy vagy két aktin monomert is megkötnek, ami kulcsfontosságú a nukleáció szempontjából, mivel az Arp2/3 komplex önmagában csak nagyon gyengén képes monomereket kötni. Ennek az utóbbi monomernek a bekötődésével létrejön egy olyan trimer, amely a nukleációs magok struktúrájához hasonlít, így elindulhat az aktin polimerizáció (Blanchoin és mtsai. 2000) (8. ábra A).

\subsubsection{WH2 domén tartalmú aktin nukleációs faktorok}

Ebbe a csoportba olyan fehérjék tartoznak, amelyek aktin monomereket kötnek meg, majd ezekből nukleációs magokat alakítanak ki. Ezek a fehérjék tandem ismétlődésként három vagy több G-aktin kötő domént tartalmaznak, amely a legtöbb esetben WH2 domént jelent, innen 
a család elnevezése. A Spire, Cordon-bleu (Cobl), és Leiomodin (Lmod) fehérjecsaládok tartoznak ide, valamint néhány bakteriális nukleációs faktor (Qualmann és Kessels 2009) (8. ábra A). A WH2 domének jelenléte miatt ezek a fehérjék evolúciós rokonságban állnak a fent említett NPF-ekkel (Dominguez 2009), habár ezek a nukleációs faktorok nem kötődnek az Arp2/3 komplexhez, és az Arp2/3 komplexszel ellentétben ezek a faktorok nem elágazó aktin filamentumok képződését katalizálják.

A csoportból elsőként a Spire-t azonosították, mint a Drosophila peték és az embriók fejlődéséhez szükséges faktort (Manseau és Schüpbach 1989), később az aktin nukleációs képességét is kimutatták (Quinlan és mtsai. 2005). Az aktin polimerizációért felelős szekvencia négy tandem ismétlődő WH2 doménből és egy járulékos aktin monomer kötő linkerből áll (8. ábra A). Fontos megjegyezni, hogy az aktin összeszerelődés során a Spire együttmüködik a forminokkal, ahogy ezt a Drosophila Spire és Capuccino fizikai kölcsönhatása bizonyította (Rosales-Nieves és mtsai. 2006). Végül, a Spire részt vesz a mikrotubulusok kötegelésében is, ami által közvetítő szerepet tölt be az aktin és a mikrotubulus rendszer közötti kölcsönhatásban (Quinlan és mtsai. 2007).

A Cobl fehérjét élesztő két-hibrid módszerrel azonosították patkány agyi extraktumból, ahol az ABP1-gyel (Actin-Binding Protein 1) és a Syndapin-nal mutatott kölcsönhatást. A Cobl eggyel kevesebb WH2 doménnel rendelkezik, mint a Spire. A polimerizáció létrejöttéhez mindhárom WH2 doménjére szükség van, annak ellenére, hogy a harmadik WH2 domén G-aktin iránti affinitása tízszer alacsonyabb, mint az első kettőé. Érdekes módon, az utolsó két WH2 domént összekötő linker hosszúsága szintén fontos az aktin összeszerelődés szempontjából. Ez arra enged következtetni, hogy az egymáshoz közeli helyzetű WH2 domének egy aktin dimert 
hoznak létre, míg a távolabb eső WH2 domén egy harmadik monomerrel lép kölcsönhatásba, így hozva létre egy olyan trimer konfigurációt, amely elősegíti a polimerizációt (8. ábra A).

A WH2 csoport harmadik tagja, a Leiomodin fehérje szívizom szövetben található. Az Lmod egyetlen WH2 domént, és két másik típusú, a Tropomodulin (Tmod) fehérjében szintén előforduló aktin kötő domént tartalmaz (Chereau és mtsai. 2008). Az Lmod ezeknek az aktin kötő doméneknek a segítségével hozza létre a 3 monomerből álló nukleációs magot, amelyet a Tmod-hoz hasonlóan valószínűleg a mínusz vég felől stabilizál (8. ábra A). Említésre méltó, hogy in vitro körülmények között a Tropomiozin serkentette az Lmod nukleációs aktivitását, akárcsak a forminok esetében (Wawro és mtsai. 2007).

\subsubsection{Aforminok}

A Formin-1-et először 1990-ben egérben azonosították, az elnevezés a limb deformity (ld) mutáció nevéből ered. Ez a mutáció homozigóta formában súlyos végtagfejlődési rendellenességeket eredményezett (Woychik és mtsai. 1990). Későbbi kísérletekben kimutatták, hogy az ld mutánsokra jellemző végtagfejlődési defektusok tulajdonképpen a szomszédos gremlin nevü gén mutációjához köthetők (Zuniga 2004). Ennek ellenére az ld gén időközben és később azonosított homológjaira a tudományos közösség megtartotta a „formin” elnevezést, mert bebizonyosodott, hogy ennek a fehérjecsaládnak a tagjai kulcsfontosságú szerepet játszanak számos sejten belüli aktin struktúra létrehozásában. Későbbi kísérletekben kimutatták, hogy a forminok jelen vannak az összes eukarióta szervezetben, ahol nagyszámú sejten belüli folyamat szabályozásában vesznek részt, beleértve a sejtpolarizáció, adhézió, osztódás és a sejtmozgás jelenségeit is (Evangelista és mtsai. 2003; Wallar és Alberts 2003). Az eukarióta szervezetek több formin gént tartalmaznak: a gombafajok 2 vagy 3, a Drosophila 6, az emlősök 15, néhány 
növényfaj pedig több mint 20 formin génnel rendelkezik (Higgs 2005; Grunt és mtsai. 2008; Chalkia és mtsai. 2008).

A forminok nagyméretü (120-220 kDa) fehérjék, számos konzervált domént tartalmaznak, melyeken keresztül sokféle fehérjével hatnak kölcsön. Akárcsak a WH2 domén tartalmú aktin nukleációs faktorok a forminok is az el nem ágazó (hosszanti lefutású) aktin struktúrák kialakulását katalizálják, közvetlenül nukleálva az aktin filamentumokat (Evangelista és mtsai. 1997; Pruyne és mtsai. 2002; Sagot és mtsai. 2002).

Minden formin fehérje legjellemzőbb doménje az FH2 (formin homológia 2) domén, amely az aktin filamentumok összeszerelödésében játszik szerepet. Az FH2 domének aminosav szekvenciájának elemzése alapján a metazoák formin génjeit hét alosztályba sorolták: Diaphanous (Dia); leukocitában azonosított formin-szerü fehérjék (formin-related proteins identified in leukocytes, FRLs); DAAM (ㅁisheveled-associated activators of morphogenesis); formin homológia domént tartalmazó fehérjék (formin homology domain-containing proteins, FHOD); forminok (FMN); Delphilin; fordított forminok (inverted formins, INFs) (Higgs és Peterson 2005) (9. ábra A).

A legjobban tanulmányozottak ezek közül a Diaphanous-szerü forminok (DRFs), ide tartoznak a Dia, a DAAM és az FRL forminok. Ezek szerkezeti szempontból két fő funkcionális régióra oszthatók: az N-terminális szabályozó régióra (amelynek a fehérje in vivo lokalizációjában van szerepe, és befolyásolni képes a C-terminális rész működését) és a Cterminális „aktív” régióra (amely elősegíti az aktin filamentum összeszerelődést, és bizonyos forminokban mikrotubulusokkal is kölcsönhat). A forminok N-terminális régiójában a GTP-áz kötő (GBD) és a Diaphanous inhibíciós (DID) domének után egy dimerizációs domén (DD) és a központi helyzetü coiled-coil domén $(\mathrm{CC})$ következik. A DD és CC doméneknek az N-terminális 
régió dimerizációjában van szerepük, mivel biofizikai módszerekkel sikerült kimutatni, hogy a formin fehérjék dimer formában aktívak (Li és Higgs 2005; Moseley és mtsai. 2004; Harris és mtsai. 2004; Harris és mtsai. 2006). Emellett a CC régiónak további szerepe lehet a forminok lokalizációjában a specifikus ligandokkal való kölcsönhatások során.
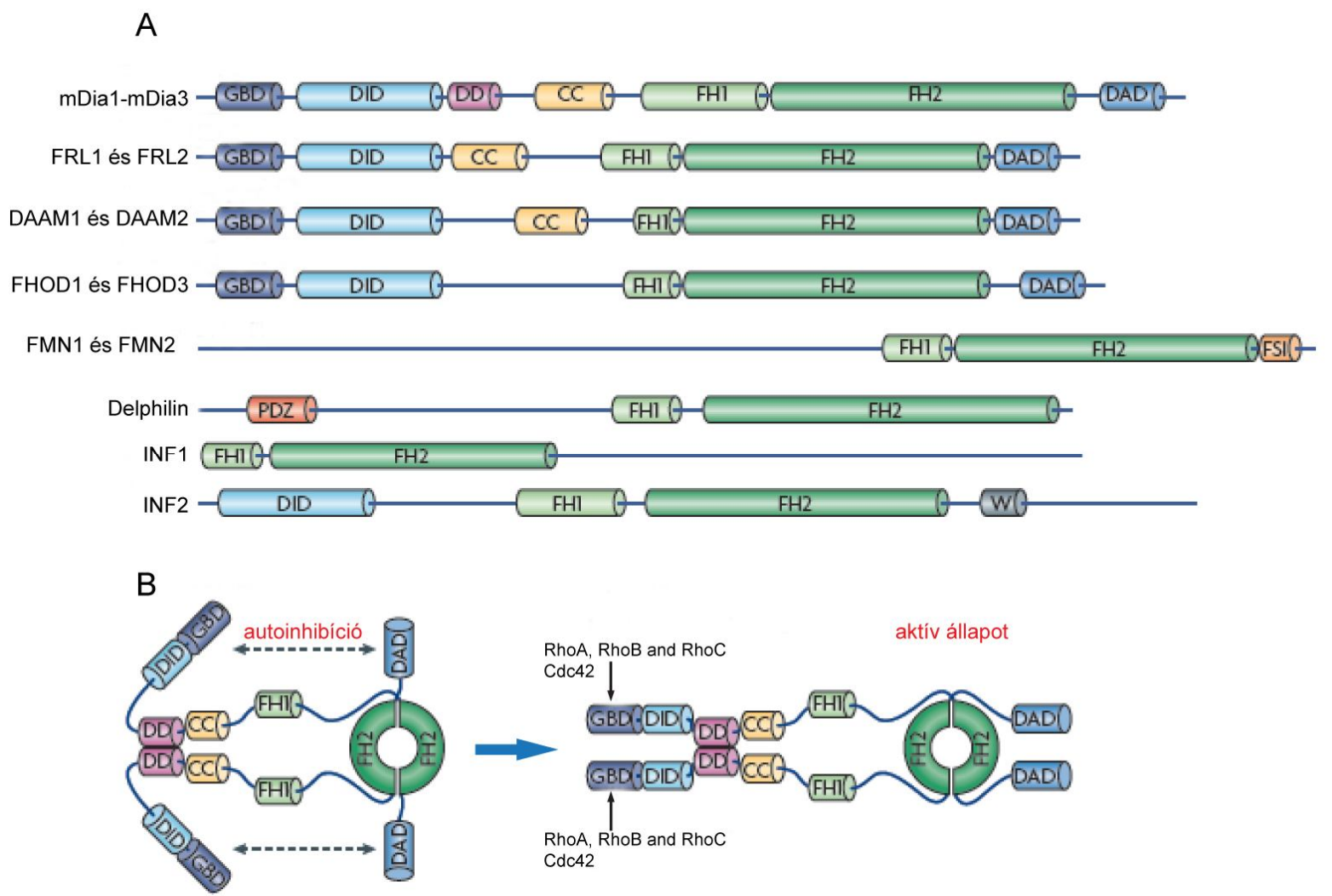

9. ábra A forminok doménszerkezete és a DRF forminok szabályozása. Az emlős formin családok doménszerkezete. Rövidítések: GBD, GTP-áz kötő domén; DID, diaphanous inhibíciós domén domén; DD dimerizációs domén; CC, coiled-coil domén; FH1 és FH2, formin homológia 1 és 2 domének; DAD, diaphanous autoregulációs domén; FSI, formin-Spire interakciós domén; PDZ, Postsynaptic density protein, Discs large, Zona occludens 1 domén; W, WASP homológia 2 domén. (B) A Diaphanous szerü forminok dimer formában aktívak, szabályozásukkor pedig az autoinhibíció a C-terminális DAD és az N-terminális DID domének kölcsönhatásával jön létre. A Rho fehérjecsaládba tartozó kis GTP-ázok GBD doménhez történő kapcsolódásával az autoinhibíciós kapcsolat megszünik, így a formin aktív állapotba kerül. Forrás: Campellone és Welch 2010.

A C-terminális rész a DRF forminok esetében a Diaphanous autoregulációs domént (DAD) hordozza, amely az N-terminálison levő Diaphanous inhibíciós doménnel (DID) összekapcsolódva inaktív konformációt alakít ki. Speciális esetekben ez az autoinhibíció megszüntethető egy Rho kis GTPáznak az N-terminálison elhelyezkedő GTPáz-kötő doménhez 
(GBD) való kötődésével (Li és Higgs 2003; Liu és mtsai. 2008a) (9. ábra B). De egyre több bizonyíték szól amellett, hogy egyéb járulékos faktorok is közrejátszanak az aktiválásban. Emellett, úgy tünik, hogy néhány formin képes aktiválni a Rho kötőpartnereit, ezáltal teremtve meg a kölcsönös aktiváció lehetőségét (Habas és mtsai. 2001; Kitzing és mtsai. 2007).

Ugyancsak a C-terminális régióban található az aktin filamentum összeszerelődést megvalósító FH1-FH2 doménekből álló modul. A prolin-gazdag FH1 doménnek nincs stabil másodlagos szerkezete, viszont ismert, hogy kötőhelyeket tartalmaz a Profilin-aktin komplexek számára. A Profilin a sejtekben az ATP asszociált aktin monomereket köti meg (Kaiser és mtsai. 1999), következésképpen a Profilin-aktin komplexek az in vivo aktin összeszerelődés meghatározó építökövei. A Profilin és az FH1 domén közötti kölcsönhatás kulcsfontosságú az aktin monomereknek az FH2 katalitikus régióhoz való szállításában (Kovar és mtsai. 2003; Yonetani és mtsai. 2008; Sagot és mtsai. 2002; Paul és Pollard 2009). A Profilinen kívül az FH1 domén kötőhelyül szolgálhat SH3 és/vagy WW doméneket tartalmazó fehérjék számára (Chang és mtsai. 1997; Evangelista és mtsai. 1997; Imamura és mtsai. 1997). Ez a domén, annak ellenére, hogy a Profilinen keresztül képes aktin monomereket megkötni, önmagában nem segíti elő az aktin nukleációt (Paul és Pollard 2009).

Az FH1 doménnel szomszédos, de annál jóval nagyobb méretü FH2 domén (kb. 450 aminosav) tekinthető a forminok katalitikus doménjének. Az FH2 doménre jellemző, hogy gyűrüszerű homodimereket alkot, amelyek körbeveszik az aktin filamentum gyorsan növekvő végét. A nukleációs lépés után a forminok az FH2 dimeren keresztül a plusz véghez kapcsolódva maradnak, így megvédik a filamentum véget a sapkázó (capping) fehérjék hozzákötődésétől, és emellett, ha szükséges, további monomerek beépülését segítik elő (ennek a jelenségnek a leírására az angol nyelvű szakirodalomban a „,processive capping” kifejezést használják). Az 
mDia1 és mDia2 esetében az FH2 domén a környező szekvenciákkal együtt a mikrotubulusokhoz is kötődik, és három mikrotubulus kötő fehérjével hat kölcsön: az endbinding protein 1-el (EB1), az adenomatous polyposis coli-val (APC), és a cytoplasmic linker protein 170-nel (CLIP170) (Wen és mtsai. 2004; Lewkowicz és mtsai. 2008; Bartolini és mtsai. 2008). Az FH2 homodimerek önmagukban is képesek katalizálni a tisztított aktin monomerek nukleációját in vitro körülmények között (Sagot és mtsai. 2002; Pring és mtsai. 2003), ugyanakkor a dimerizáció feltétlenül szükséges, mert azok a mutációk, amelyek megzavarják a dimerizációt, megszüntetik a polimerizációs aktivitást is (Moseley és mtsai. 2004; Copeland és mtsai. 2004; Xu és mtsai. 2004).

Az élesztő Bnil (Xu és mtsai. 2004) és az emlős FH2 domének (Lu és mtsai. 2007; Shimada és mtsai. 2004) kristályszerkezetének tanulmányozása azt mutatta, hogy a dimerizáció során a két FH2 domén rugalmas, pányva-szerü aminosavak segítségével kötődik egymáshoz, és így alkot egy gyürüszerü struktúrát. A Bni1 FH2 doménjét tetrametil-rodaminnal jelölt aktinnal együtt is sikerült kristályosítani, és azt figyelték meg, hogy a dimerizált FH2 gyürü két aktin monomert köt, és ezeket olyan konformációba hozza, ami hasonlít az F-aktinra jellemző aktin dimerek szerkezetéhez (Otomo, Tomchick és mtsai. 2005). Ez arra utal, hogy az FH2 mediálta nukleáció magában foglalja az aktin dimerek stabilizációját is.

A fent említett FH2-aktin szerkezet, továbbá heterodimerikus FH2 mutánsok viselkedése alapján állították fel a forminok általános működési modelljét. Eszerint az FH2 dimer kezdetben két aktin monomert köt, mely a későbbiekben nukleációs magként szolgál a további aktin polimerizáció számára. Az FH2 dimer két különbözö állapotban létezik a gyorsan növekvő végen. A zárt konformációban a további monomer beépülés nem lehetséges. A beépülés csak nyitott konformáció esetén történhet meg, és ez úgy valósul meg, hogy a plusz vég felé 
elhelyezkedő hemidimer nyitottá válik és megtörténik az új aktin alegység hozzáadása, míg a mínusz vég felé eső hemidimer zárt állapotban található. A monomer beépülése után viszont az FH2 domén ismét zárt konformációt vesz fel. Az FH2 hemidimerek váltakozó nyitott és zárt állapotai eredményeképpen az FH2 dimer a beépülö monomereken való „továbblépéssel” (stair stepping mechanism) lehetővé teszi az új aktin alegységek hozzáadását (Otomo és mtsai. 2005) (10. ábra).

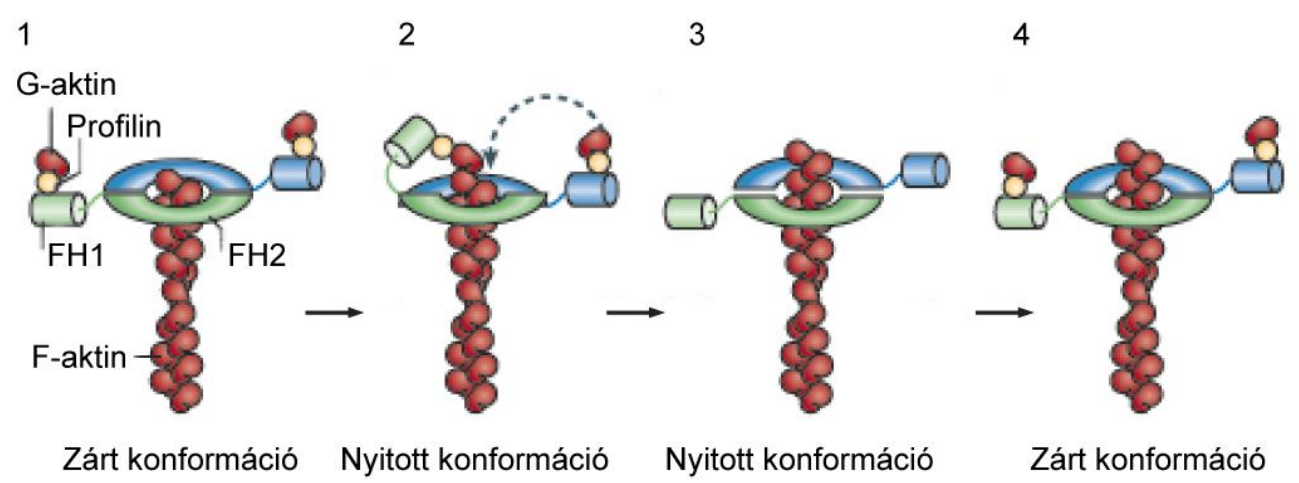

10. ábra A forminok általános múködési modellje. Az FH2 dimer az aktin-filamentumok plusz végéhez kötődik, az aktin polimerizációhoz szükséges monomereket az FH1 domén biztosítja a Profilin-G-aktin megkötésével (1). Az FH1 domén a Profilin-G-aktint a plusz vég közelébe szállítja, ahol az FH2 dimer egyik funkcionális fele építi be az aktin monomert a filamentum végére (2). A második FH2 domén megismétli ugyanezt a folyamatot (3). A formin zárt konformációja megóvja a filamentum véget a capping fehérjék hozzákötődésétől (4). Forrás: Campellone és Welch 2010.

Néhány formin a nukleációs és elongációs aktivitáson kívül más szerepet is betölt. Például az élesztő formin Bni1, az egér mDia2, FRL1, FRL2, FRL3, a Drosophila DAAM és az Arabidopsis FORMIN-LIKE 1 az aktin filamentumok kötegelésére is képesek (Moseley és Goode 2005; Harris és mtsai. 2006; Michelot és mtsai. 2005; Vaillant és mtsai. 2008; Barkó és mtsai. 2010). Az egér FRL1, INF2 és az Arabidopsis FH8-ról pedig kimutatták, hogy a filamentumok feldarabolásában vagy depolimerizációjában is szerepet játszanak (Harris és Higgs 2004; Chhabra és Higgs 2006; Yi és mtsai. 2005). A filamentumok kötegekbe rendezése az olyan párhuzamos lefutású aktin struktúrák kialakításakor lehet különösen fontos, mint amilyenek a filopódiumok és a stressz-rostok. A filamentum feldarabolásnak az aktin struktúrák gyors 
átrendezésében lehet szerepe, de ez a formin szerepkörnek egy olyan aspektusa, amit in vivo körülmények között még nem vagy alig tanulmányoztak.

\subsection{Aktin összeszerelődés és filamentumhossz szabályozás a harántcsíkolt izmokban}

A harántcsíkolt izmok vékony filamentumainak elongációját patkány kardiomiocita és Drosophila primer embrionális sejttenyészetekben is tanulmányozták, és a nem-izom sejtekkel ellentétben azt találták, hogy in vivo monomer beépülés nem csak a plusz végen történik, hanem a mínusz vég irányából is (Bai és mtsai. 2007; Littlefield és mtsai. 2001; Mardahl-Dumesnil és Fowler 2001; Pollard és mtsai. 2007). Ráadásul arra is fény derült, hogy a miofibrillumok fejlődése során jelentősen nagyobb az elongáció sebessége a mínusz végen, mint a plusz végen. Ez mindenképpen meglepő megfigyelés volt, hiszen a mínusz végi elongáció in vivo teljesen ismeretlen a szakirodalomban, és mivel eddig nem írtak le mínusz vég elongáló faktorokat, annak mechanizmusa egyáltalán nem nyilvánvaló. Mindemellett az elmúlt években több olyan fehérjét is jellemeztek, ami kapcsolatba hozható a miofibrilláris vékony filamentumok kialakulásával.

Az egyik első jelölt az Lmod aktin nukleációs faktor volt, amelyről kimutatták, hogy sejtkultúrákban nélkülözhetetlen szerepet játszik a miofibrillogenezisben. Az Lmod a vékony filamentumok mínusz végeinél lokalizálódik, az érett miofibrillumok M-vonalához közel (Chereau és mtsai. 2008). A Lmod fehérjeszintjének RNS interferenciával való csökkentése súlyos zavarokat okoz a szarkomer összeszerelődésben, de az $\alpha$-aktinin periodikus elrendeződése az aktin filamentumok mentén fennmarad. Ezért valószínü, hogy egy másik aktin nukleációs faktor is szükséges a szarkomerogenezis kezdeti lépéseihez. Később azt is kimutatták, hogy sejttenyésztett kardiomiocitákban az Lmod expressziós szintje az izomrostok kialakulásának későbbi stádiumában növekszik csak meg, és a fehérje csak a differenciálódott 
miofibrillumokban halmozódik fel. Ezek alapján feltételezik, hogy az Lmod-nak csak a végső szarkomer szerkezet kialakításában és fenntartásában van szerepe, de nem szükséges a miofibrillogenezis kezdeti lépéseihez (Skwarek-Maruszewska és mtsai. 2010).

A másik aktin összeszerelő faktor, amit kapcsolatba hoztak a szarkomerikus aktin filamentumok kialakulásával, a forminok közé tartozó Formin Homology 2 Domain Containing 3 (Fhod3) volt. Az emlős Fhod3 fehérjéről kimutatták, hogy kardiomiocita sejttenyészetben részt vesz a szarkomer szerveződésben. A Fhod3 fehérje szintjének RNS interferenciával való csökkentése a filamentáris aktin jelentős megfogyatkozását és a rendezett szarkomerikus struktúra felbomlását eredményezte. A Fhod3 azonban in vitro körülmények között még Profilin jelenlétében is gátló hatással volt az aktin polimerizációra. Másrészt a homozigóta fhod3 mutáns egerek szívében is fejlődtek miofibrillumok, így a Fhod3 szerepe a miofibrillogenezisben hasonlónak tünik az Lmod-hoz: valószínüleg nem a kezdeti lépésekben van szerepe, hanem inkább a már kialakult szerkezet fenntartásában (Taniguchi és mtsai. 2009; Kan-O és mtsai. 2012).

Az aktin nukleációs faktorokon kívül a Drosophila SALS (arcomere Length $\underline{\text { Shortening) }}$ fehérjét is kapcsolatba hozták az aktin filamentum növekedéssel. A SALS egy esszenciális fehérje, a sals mutánsok nagy része a lárvális fejlődési stádiumban elpusztul. Ezeknek a mutánsoknak az izmai normális számú, de jelentősen megrövidült szarkomerből állnak, ami arra utal, hogy bennük rövidebbek a vékony filamentumok, mint a vad típusban. Genetikai adatok alapján a SALS in vivo funkcionálisan antagonizál a mínusz vég sapkázó (lásd alább) Tmod fehérjével, ezáltal segítve elö a filamentum elongációt. Meglepő módon azonban, in vitro körülmények között a SALS kölcsönhatást mutat az aktinnal, de gátolja az aktin polimerizációt. Ezek alapján feltehetően ennek a fehérjének sincs szerepe a miofibrillogenezis kezdeti lépései 
során (nem szükséges a szarkomerek kialakulásához), csak a szarkomerek növekedésében játszik szerepet (Bai és mtsai. 2007). A szarkomerikus aktin filamentumok képződésének a kezdeti lépéseken túl a hossz szabályozás is egy fontos eleme, hiszen a szarkomerek hosszát döntően az aktin filamentumok hossza határozza meg. A hossz-szabályozás vonatkozásában ismert, hogy a filamentum végeket sapkázó (capping) fehérjék tartják lezárva. Ezek megakadályozzák a további monomer beépülést, illetve disszociációt, ily módon stabilizálják a filamentumok hosszát. Az eddig leírt sapkázó fehérjék közül a CapZ a plusz, míg a Tmod a mínusz végeket képes lezárni (Au 2004). Irodalmi adatok alapján (Littlefield és mtsai. 2001) ez a két fehérje harántcsíkolt izmokban is képes kötődni az aktin filamentumok végéhez, és hozzájárulnak a vékony filamentumok hosszának szabályozásához.

Összefoglalva elmondható, hogy a szarkomerikus aktin filamentumok kialakulásáról és hosszának szabályozásáról már vannak ismereteink, de a kezdeti aktin összeszerelő faktor és a molekuláris mechanizmus egyelöre ismeretlen. Jelen dolgozatban arról számolok be, hogy a formin fehérje család egy másik tagjáról, a DAAM alcsalád Drosophila képviselőjéről sikerült bizonyítanunk, hogy szükséges a vékony filamentumok kezdeti összeszerelődéséhez, és eredményeink alapján javaslatot teszünk egy új mínusz vég elongációs mechanizmusra. Saját egér sejtkultúrákban végzett kísérleteink és mások genetikai vizsgálatai alapján feltételezhető, hogy a DAAM alcsalád szerepe a miofibrillogenezisben evolúciósan konzervált. Az eredmények ismertetése elött a bevezetés utolsó fejezetében áttekintem a DAAM alcsaládba tartozó forminok legfontosabb jellemzőit.

\subsection{A DAAM formin alcsalád}

A DAAM alcsaládba tartozó formin típusú fehérjéket először a citoplazmatikus foszfoprotein Dishevelled-like (Dvl) kölcsönható partnereként azonosították, innen ered az 
elnevezésük is: Dishevelled associated activator of morphogenesis (Habas és mtsai. 2001). A Dishevelled (Dsh/Dvl) fehérje család tagjai a Wnt/Frizzled jelátviteli út jól ismert elemei. Különböző modellrendszereken végzett kutatások alapján tudjuk, hogy a Wnt ligandok által aktivált Frizzled receptorok több, sejten belüli szignál transzdukciós utat is aktiválhatnak. Ezek közül a $\beta$-katenin függő utat kanonikus Wnt/Frizzled jelátviteli útnak nevezzük, míg az úgynevezett szöveti polaritási vagy ,planar cell polarity” (PCP) fehérjéktől függő útvonalat Wnt/PCP vagy nem-kanonikus útnak nevezzük (Komiya és Habas 2008). Ellentétben a Dsh fehérjével, ami mind a kanonikus, mind pedig a nem-kanonikus Wnt/Frizzled jelátviteli rendszer működéséhez szükséges, a DAAM fehérje család szerepe kizárólag a Wnt/PCP útvonal müködéséhez köthetö, de nem szükséges a kanonikus Wnt jelátvitelhez. Ahogy fentebb már utaltam rá, a DAAM alcsalád szekvencia homológia és müködésmód alapján is a DRF alcsaládhoz tartozik. Ezek a forminok a DID és DAD doménjükön keresztül autoinhibícióval szabályozódnak, amit Rho GTPázok képesek megszüntetni. Az egér és humán DAAM fehérjék FH2 doménjének in vitro vizsgálatával kimutatták (Lu és mtsai. 2007, Yamashita és mtsai. 2007), illetve csoportunk Nyitrai Miklós (PTE, Biofizikai Intézet) kutatócsoportjával együttmüködve a Drosophila DAAM biofizikai vizsgálatával megállapította, hogy a DAAM FH2 domén bona fide forminként viselkedik az aktin nukleációs és polimerizációs kísérletekben. Azt is sikerült megmutatnunk, hogy a dDAAM FH1 doménje az aktin összeszerelődés során kölcsönhat a Profilin-aktin komplex-szel (Barkó és mtsai. 2010).

Szekvencia analízis alapján a gerinces fajok genomja három DAAM ortológot kódol, amelyek kifejeződési mintáját egérben, karmos békában és csirkében is tanulmányozták. Az expressziós minta az embriogenezis során térben és időben is dinamikusan változik. Az expresszió a fejlődő központi idegrendszer (CNS) területén, a szomitákban, a dermomyotomok 
szintjén és a szívben a legmagasabb az összes vizsgált fajban. Érdekes módon az embrionális CNS-en belül az agy, a gerincvelő és a retina területén a Daam1 és a Daam2 gének egymást kiegészítő génexpressziós mintázatot adnak (Kida és mtsai. 2004; Nakaya és mtsai. 2004). A DAAM fehérje család funkcionális jellemzése során azt találták, hogy a Daam1-nek kulcsszerepe van a Wnt/PCP jelátvitelben a Xenopus gasztruláció során. Később gerinces szövettenyészeteken a DAAM-nak egy sor olyan, a sejtmüködésben végzett szerepét tárták fel, ami összhangban van a forminok általános, a citoszkeletális szabályozásban betöltött funkcióival. Ide tartozik a Daam1 által a sertés-aorta endoteliális sejtek alakjának és elágazódásainak a szabályozása; résztvétel a vérlemezkékben zajló RhoA-függő aktin összeszerelődésben (Higashi és mtsai. 2008); az endoteliális sejtek vándorlásának és proliferációjának a gátlása, és a mikrotubulusok stabilizációja ezekben a sejtekben (Ju és mtsai. 2010); a stressz-rostok kialakulásának és a centroszóma reorientációjának a szabályozása COS-7 és U2OS sejtekben (Ang és mtsai. 2010). Az mDaaml egér mutánsok vizsgálatával arra derítettek fényt, hogy ez a fehérje fontos szerepet játszik a szívfejlődésben és a szarkomerek kialakulásában. Elképzelhető, hogy a szívfejlődési rendellenességek eredendően bal-jobb aszimmetria zavarokat tükröznek, ami összhangban lenne azokkal a további megfigyelésekkel, melyek szerint a DAAM fehérjék hozzájárulnak az idegrendszeren (Lee 2012; Colombo 2013) és a bélrendszeren (Welsh, 2013) belüli aszimmetriák kialakításához csirke és zebrahal modellrendszerekben.

A fentiek alapján világos tehát, hogy a sejtváz szabályozó fehérjék evolúciósan nagymértékben konzerváltak. Ezért a dDAAM fehérjével végzett kísérletek tovább bővíthetik az emlős DAAM és a vele rokon forminokra vonatkozó ismereteinket. 


\section{CÉLKITÜZÉSEK}

A Drosophila DAAM jellemzése során csoportunk megfigyelte, hogy a gén erős expressziót mutat a 12. embrionális stádiumban a fejlődő szívcső kardioblasztjaiban, majd később a fejlődő testfal izmokban is. Ezek után kimutattuk, hogy a fehérje jelen van az adult szívcsőben és az indirekt repülőizomban is. Embrionális és adult korú egér izommetszetek immunfestése után azt tapasztaltuk, hogy a mDaam1 a Drosophila izmokban tapasztalt lokalizációs mintázathoz hasonló képet ad egér izmokban. Tekintve, hogy a szarkomerikus aktin filamentumok kialakulásának mikéntje munkánk kezdetén jórészt ismeretlen volt, előzetes eredményeink alapján úgy gondoltuk, érdemes részletesen is megvizsgálni milyen szerepet tölthet be a dDAAM fehérje a miofibrillogenezis során. Mivel a forminok a nem-elágazó, hosszú aktin filamentumok összeszerelődését katalizálják, és a harántcsíkolt izomsejtek egyik fó alkotóeleme éppen az ilyen típusú filamentum, mindenképpen elképzelhető volt, hogy egy formin családba tartozó fehérje kulcsszerepet játszik a vékony filamentumok összeszerelődésében. Első lépésként a dDAAM fehérje lokalizációját kívántuk még alaposabban vizsgálni a muslica indirekt repülőizmainak szarkomerjeiben. Szándékunkban állt a vizsgálatokat a vad típuson kívül kiterjeszteni a fehérje funkcióvesztéses mutánsaira, valamint fehérje túltermeléses mutánsokra is. Funkcióvesztéses mutánsok és RNS csendesítő konstrukciók segítségével terveztük vizsgálni, hogy van-e szerepe a $d D A A M$-nak az aktin filamentumok kialakulásában és a szarkomerek összeszerelődésében. További tervünk volt a dDAAM molekuláris funkciójának vizsgálata, és a dDAAM-mal együttmüködő izomfehérjék azonosítása, genetikai interakciós kísérletek, illetve biokémiai kísérletek során.

Mindezek alapján reméltük, hogy a dDAAM működésmódjának jobb megértése egyben a szarkomer összeszerelődés mechanizmusáról is értékes információkat szolgáltat majd. 


\section{EREDMÉNYEK}

\subsection{A dDAAM mutáns izmok fenotípusa és élettani jellemzése}

\subsubsection{Az indirekt repülöizom szerkezete és fejlödése}

Dolgozatom legnagyobb része a $d D A A M$ génnek az indirekt repülőizom (Indirect Flight Muscle, IFM) fejlödése során betöltött szerepével foglalkozik. Emiatt a bemutatott eredmények jobb megértése érdekében szükségesnek tartom, hogy elöljáróban ennek az izomnak a fejlődéséről és szerkezetéről egy rövid összefoglalót adjak.

A Drosophila IFM-et (11. ábra A) szerkezeti, élettani és fejlődési sajátosságai együttesen kiváló izom modellé teszik. Az alábbiakban ezeket az előnyöket ismertetném. Ebben az izomban a bábállapot túlnyomó részében a miofibrillumok egyidöben nagymértékü hossznövekedésen mennek keresztül. E növekedés minden stádiumában az izom szerkezete szigorúan rendezett, így a szerkezeti hibák könnyen detektálhatóak. Az izom állapota nem befolyásolja az életképességet, de a legkisebb változás is a szarkomer morfológiájában, amely még elektronmikroszkóppal sem detektálható, adult állapotban a röpképesség megszünését vonhatja maga után. Ezeket a röpképtelen egyedeket pedig könnyen ki lehet szürni egy egyszerü repülési tesztben. На a repülési tesztben nincs szignifikáns eltérés a vad típushoz képest, akkor értelmetlen molekuláris szintü vizsgálatokat végezni.

A kétszárnyúakban (Diptera), és így Drosophilában is, az IFM-nek egyedi a szerkezete. Anatómiailag a legjobban a gerinces szívizomra hasonlít (Maughan és Vigoreaux 1999), egyedi rostokra szedhető szét, és ily módon különbözik a tubuláris szerkezetü egyéb adult és lárvális rovarizmoktól. Arra a kérdésre, hogy ennek az izomnak miért alakult ilyen rendhagyóvá a szerkezete és a fejlődése, a válasz a muslica repülési mechanizmusában keresendő. A direkt szárnymozgató izmoknak csak a manőverezésben van szerepük repülés közben. A konkrét erőt, 
ami a szárnyak felemeléséhez és lecsapásához szükséges, azt az indirekt repülöizom biztosítja. Ez az erő nem annyira a szárnyak alapjára hat, hanem a tor alakját változtatja. Az IFM két fő izomcsoportból, a dorzoventrális (DVM) és a dorzolongitudinális (DLM) izomcsoportból áll. A dorzoventrális izomcsoport összehúzódásával lapítja a tor kitinvázát és ezáltal a szárnyakat emeli. A dorzolongitudinális izomcsoport antagonistaként müködik: a tor kitinvázának a felső részét emeli és ezáltal a szárnyak lefelé irányuló mozgását biztosítja (11. ábra B és C) (Fernandes és mtsai. 1991).
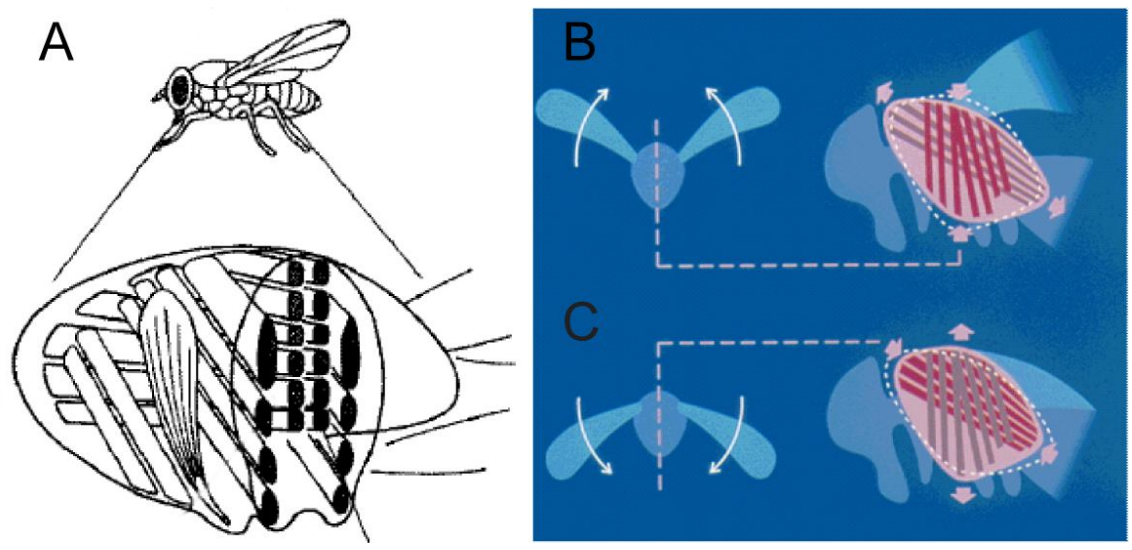

11. ábra Az IFM szerkezete. (A) Az adult állatok torának nagy részét az indirekt repülőizom nagy tömege tölti ki. Az IFM két antagonista izomcsoportból áll. A dorzoventrális (DVM) 7 izomrostból álló izomcsoport (B), összehúzódásával lapítja a tor kitinvázát és ezáltal a szárnyakat emeli. A 6 izomrostból álló dorzolongitudinális (DLM) izomcsoport (C) a tor kitinvázának a felső részét emeli és ezáltal a szárnyak lefelé irányuló mozgását biztosítja. Forrás: Maughan és Vigoreaux 1999; Vigoreaux 2001.

Az izom összehúzódása független az idegi impulzusoktól (aszinkron aktiválódású izom), az antagonista izomcsoportok folyamatosan ingerelt állapotban vannak, összehúzódásaikat az idegi utasításokon kívül a megfeszülésük is kiválthatja. Ebben az állapotban ezek az antagonista izomcsoportok egymást feszítve kölcsönös összehúzódási és elernyedési ciklusokon mennek keresztül, így érve el egy bizonyos összehúzódási frekvenciát. Ezt a frekvenciát nem az idegi impulzusok szabják meg, hanem a tor vázának a tulajdonságai. Így a szárnycsapások száma jóval magasabb értéket érhet el, mint ha folyamatos idegi impulzusok biztosítanák külön-külön az antagonista izmok összehúzódását (Bate és Arias 1993). Az izommüködésnek ez az aszinkron 
módja kizárólag csak a rovaroknál előforduló „találmány”, a legnépesebb rovarrendek (Diptera, Hymenoptera, Heteroptera és Coleoptera) tagjaira jellemző, mint evolúciós adaptáció a magas frekvenciájú szárnycsapások eléréséhez. Tekintve, hogy a muslica átlagos szárnycsapási frekvenciája másodpercenként 240, az IFM a leggyorsabban összehúzódó izmok közé tartozik (Maughan és Vigoreaux 1999; Swank és mtsai. 2006).

Az IFM fejlődése a mioblasztok vándorlásával kezdődik, melyek a korai bábban elvándorolnak a szárny imágókorong notum régiójából és megtelepednek a lárvális ferde izmok maradékán (Larval Obblique Muscles, LOM). Ezek a lárvális szomatikus testfal izmok mintaként szolgálnak a dorzolongitudinális izomcsoport kialakulásához. A mioblasztok itt fuzionálnak és létrehozzák az IFM dorzolongitudinális és dorzoventrális izomcsoportját. A fúzió idején az izmok hosszanti növekedésen mennek keresztül, kitöltik a fejlődő tort, az ínsejtekhez kapcsolódnak, és ezek után a harmadára csökken a méretük. Erre az időszakra az adult szarkomer vázfehérjék magas expressziója jellemző. A szarkomer összeszerelődése ebben az időszakban történik, ezután az izmok újból megnyúlnak, az ínsejtek visszahúzódnak, az izmok kitöltik a rendelkezésükre álló teret (12. ábra), és kialakulnak a funkcionálisan aktív miofibrillumok.

A szarkomer fejlődésében a kritikus kezdeti időszak a bábállapot harmincadik és negyvenedik órája közötti időszakra esik. Ezután a szarkomerek száma már nem változik, csak a méretük növekszik, amíg el nem éri a $\sim 3,2 \mu \mathrm{m}$ végleges hosszúságot (Nongthomba és mtsai. 2004; Weitkunat és mtsai. 2014). Ennek megfelelően, látványos izomfejlődés zajlik le ebben az időszakban. Az IFM dorzolongitudinális izomcsoportjában a miofibrillumok 310 szarkomerből állnak, a bábállapot kialakulásától számított 48 órás muslicákban a szarkomerek hossza $\sim 1,7 \mu \mathrm{m}$, az általuk alkotott izom hossza $\sim 500 \mu \mathrm{m}$. A fiatal adultokban ugyanaz a 310 szarkomer már 3,2 
$\mu \mathrm{m}$ hosszú, az izom hossza pedig eléri az 1000 m-t. Tehát a szarkomerek szintjén a növekedés majdnem kétszeres, és hogy ez megvalósulhasson, ahhoz a vékony és vastag filamentum rendszer egyidejü növekedésére van szükség a miofibrillum összeszerelődése során (Reedy és Beall 1993).

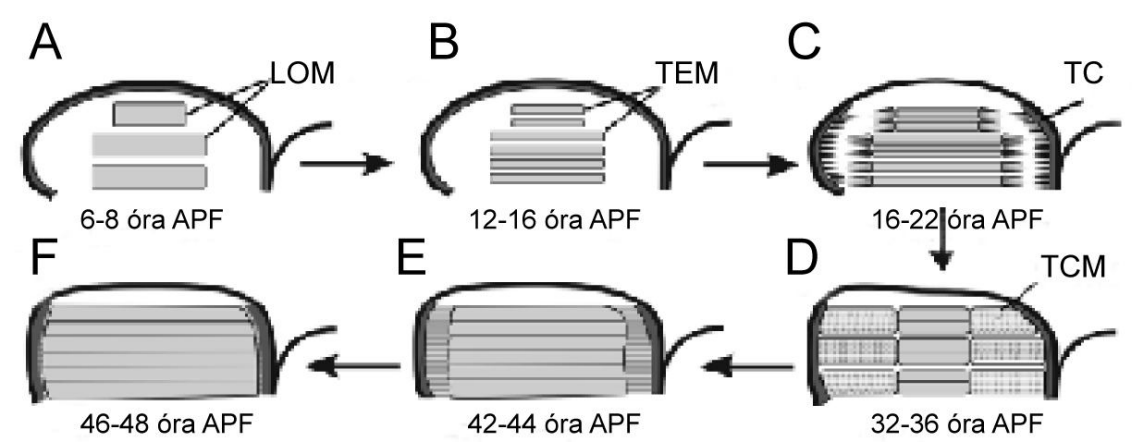

12. ábra A DLM fejlődése során bekövetkező rostképződés és sejtosztódásos folyamatok. (A) A DLM az olyan mioblasztok fúziójából jön létre, amelyek a LOM-on telepedtek meg. (B) A LOM nem megy át a teljes hisztolízisen és a továbbiakban templátként (TEM) szolgál. (C) Az IFM a mioblaszt fúziónak köszönhetően megnyúlik, és az ínsejtekhez (tendon cells, TC), kapcsolódik. (D) Az izomrostok megrövidülését követően elkezdődik a miofibrillogenezis. (E) Az egymásba kapcsolódó izom és ínnyúlványok (TCM) visszahúzódnak ahogy az izmok mérete növekszik, addig amíg a funkcionálisan aktív miofibrillumok (F) ki nem alakulnak. Forrás: Nongthomba és mtsai. 2004.

\subsubsection{A dDAAM-nak az izomfejlödésben betöltött szerepét vizsgáló kísérletek elözményei}

Az elmúlt néhány évben csoportunk egy formin alcsaládba tartozó fehérjének, a dDAAM-nak (Habas és mtsai., 2001) a funkcionális vizsgálatával foglalkozott. Szekvencia analízis alapján ez az egyetlen Drosophila DAAM ortológ, és a CG14622 jelü annotált génnek felel meg, ami az X kromoszóma csúcsán az 1F citológiai régióban található. A Drosophila genetikai adatbázis (FlyBase) több dDAAM transzkript lehetőségét felveti, ezek közül csoportunk elsősorban a CG14622-RB jelüre fókuszált, melyet az RE67944 jelzésű EST klón kódol. Megszekvenálva ezt a teljes hosszúságú cDNS klónt, egy 1153 aminosavból álló fehérje prediktálható. További vizsgálatok kimutatták, hogy az ORF valóban tartalmazza a forminokra jellemző konzervált doméneket, úgy mint az FH1, FH2, GBD és DAD domént (13. ábra A). A dDAAM funkcionális analíziséhez csoportunk funkcióvesztéses mutánsokat hozott létre két 
transzpozon inszerciót EP(1)1336 és EP(1)1542 felhasználva, melyek a dDAAM lokusz közvetlen közelében találhatóak (13. ábra A). Ezen inszerciók remobilizációjával sikerült izolálni deléciós allélokat, melyek közül kettő a dDAAM 5' régiójára térképeződött, öt pedig a 3' régiót érintette.

A nagyméretü 5' deléciók csak 5' UTR exonokat és intronikus szekvenciákat érintenek. A 3' allélok jóllehet kisebb deléciókat (965-2538 bp) hordoznak, de a dDAAM ORF-et is érintik. A deléciók közül a legkisebb, a $d D A A M^{E x I} 12$ aminosavat távolít el a prediktált fehérje Cterminális részéröl, a legnagyobb, a $d D A A M^{E x 68}$ pedig 457 aminosavat (13. ábra B). Mind az 5', mind a 3' deléciók letálisak homo-, illetve hemizigóta formában, kivéve a $d D A A M^{E x I}$-et, amely homozigóta életképes és fertilis allél (a vad típushoz viszonyított életképessége viszont csak 17\%-os). A letális 5' és 3' deléciók nem komplementálják sem egymást sem ezt a régiót átfedő deléciókat [Df(1)AD11, $D f(1) A C 7$, és $D f(1)$ sta]. Komplementálhatók azonban két transzpozíciós duplikációval $[D p(1 ; 3)$ sta és $D p(1 ; Y) S z 280]$, amelyek hordozzák az 1F2-3 citológiai régiót, ahová a $d D A A M$ lokalizálódik. A két legnagyobb deficiencia allél, a $d D A A M^{E x 68}$ és a $d D A A M^{E x 36}$ kivételével minden letális allél életképes a $d D A A M^{E x I}$ felett. Annak bizonyítására, hogy a letalitás a dDAAM fehérje hiányának köszönhető, létrehoztak olyan transzgenikus muslicákat, melyek hordozzák az UAS-FL-DAAM konstrukciót, amelybe a teljes hosszúságú RE67944 cDNS-t klónozták. Ezt a konstrukciót aztán menekítési kísérletben tesztelték. Ha az UAS-FLDAAM-ot Actin-Gal4 vagy tubulin-Gal4 szabályozás alatt expresszálták mutáns háttéren, a letalitás menekíthető volt még a $d D A A M^{E x 68}$ esetében is. Összegezve, ezek az eredmények bizonyították, hogy minden letális allél $d D A A M$ allél, és ezek a mutációk nem érintenek más esszenciális genetikai elemet. 

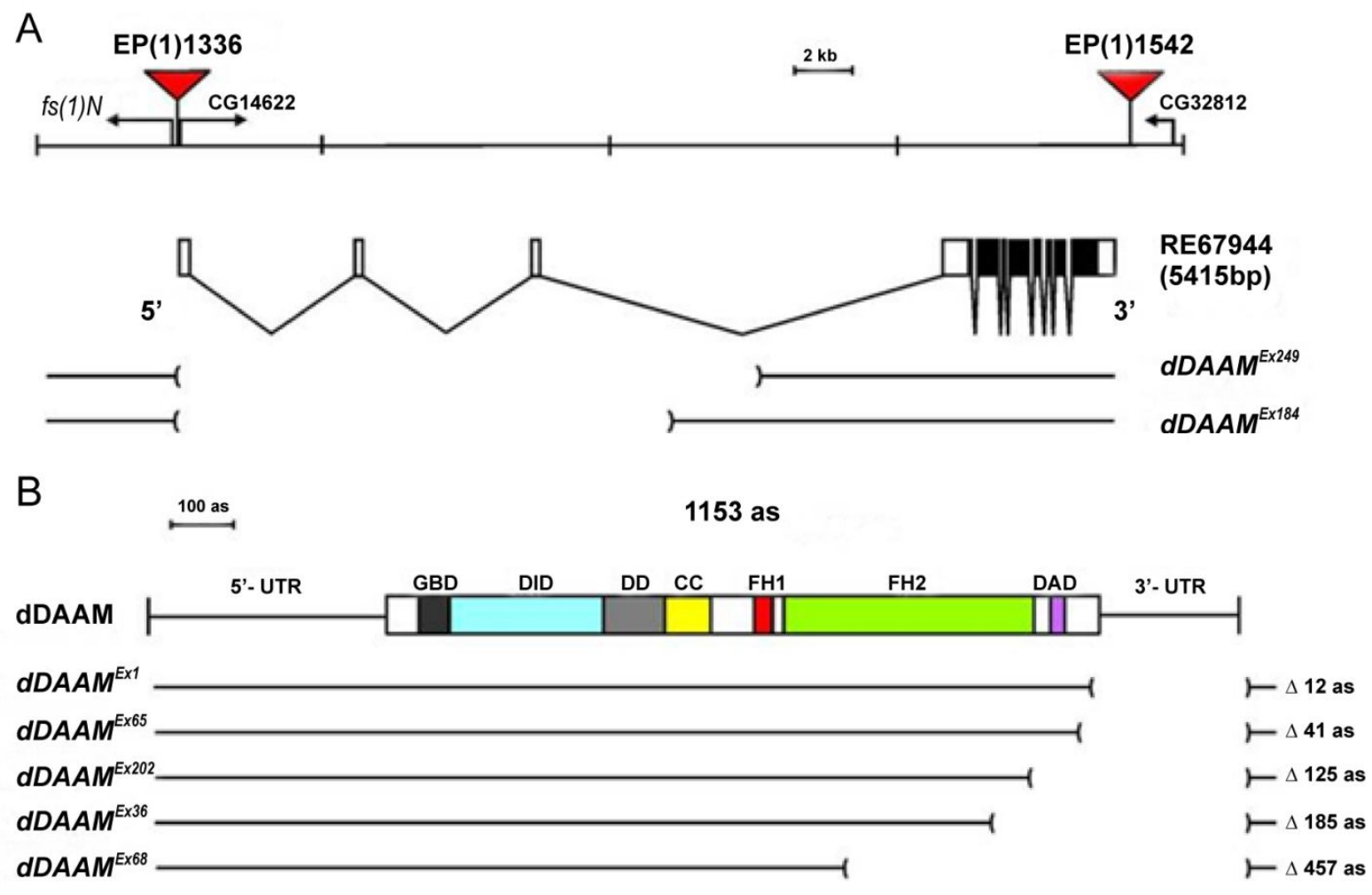

13. ábra A $\boldsymbol{d D} A \boldsymbol{A} M$ gén szerkezete, a dDAAM homológia doménjei, és a deléciós allélok helyzete. (A) Az 1F2-3 citológiai pozícióban található a CG14622 annotációs számnak megfelelő egyetlen Drosophila DAAM ortológ. A funkcióvesztéses allélok elóállítására használt két P elem, az EP(1)1336 és az EP(1)1542 pozícióit piros háromszögek jelzik. Ex249 és Ex184 a neve a két nagyméretű 5' deléciónak. (B) A teljes hosszúságú dDAAM cDNS-e egy 1153 aminosavat tartalmazó fehérjét kódol, melyben megtalálhatóak a DRF forminokra jellemző homológia domének. Az ábra alján a 3' deléciók pozícióját tüntettük fel.

A funkcióvesztéses (Loss of Function, LOF) vizsgálatokat megkönnyítendő, csoportunkban előállítottak egy T129M nevü RNS interferencia konstrukciót is. Embriókon végzett RNS in situ hibridizációs kísérletek alapján a dDAAM fehérje több szövetben is kifejeződik.

Ezeken a szövetspecifikus funkciókon kívül azt is észrevettük, hogy a gyenge hipomorf $d D A A M^{E x I}$ allélt hordozó, ezért hemizigóta formában is életképes adult hímek röpképessége gyengébb a vad típusnál. Mivel a röpképtelenséget leggyakrabban az IFM szerkezetében bekövetkezett változások okozzák, immunhisztokémiai módszerekkel vizsgáltuk tovább az izmot. Megállapítottuk, hogy a dDAAM fehérje az IFM szarkomerein belül a Z-korongok és az M-vonal környékén lokalizálódik. Mivel ez a lokalizációs eredmény egy érdekes, eddig nem 
tanulmányozott szerepre utalt, elhatároztuk, hogy részletesebben is megvizsgáljuk, vajon mi módon vehet részt a dDAAM fehérje az indirekt repülőizom fejlődésében.

\subsubsection{A dDAAM mutáció befolyásolja a röpképességet és az indirekt repülöizom fejlödését}

A Drosophila DAAM forminnal végzett kísérleteink során kimutattuk, hogy a homozigóta életképes $d D A A M^{E x I}$-es allélt hordozó muslicák 16\%-a röpképtelen szemben a vad típusnál tapasztalt 4,5\%-os röpképtelenségi aránnyal. Ez a röpképtelenségi arány gyenge, moderált fenotípusnak számít, de ez nem meglepő adat egy hipomorf allél esetében. Mivel a dDAAM null allélok homozigóta formában letálisak, úgy próbáltunk erősebb funkcióvesztéses fenotípusokat létrehozni, hogy RNS interferenciás kísérletekkel csökkentettük a dDAAM fehérje szintjét vad típusú és $d D A A M^{E x I}$-es állatokban, és így vizsgáltuk a röpképességben bekövetkezett esetleges változásokat.

Az RNS interferenciás kísérletekhez kétféle RNS interferencia konstrukciót használtunk. A $T 129 M$ nevü konstruktot a csoportunk már korábban létrehozta $\left(\mathrm{RNSi}^{\mathrm{T} 129 \mathrm{M}}\right)$. A KK102786 nevü RNS interferenciás konstrukciót pedig a bécsi RNS interferencia törzsgyüjteményből (VDRC) szereztük be $\left(\mathrm{RNSi}^{\mathrm{VDRC}}\right)$. A két konstrukt a $d D A A M$ génről képződő mRNS nem átfedő részeit célozza meg. Az RNS interferenciás kísérletekhez indirekt repülőizom specifikus Gal4 meghajtó elemet (UH3-Gal4) (Katzemich és mtsai. 2012) és UAS-Dicer2-t használtunk. A Dicer2 túltermelése posztmitotikus sejtek esetén célszerü, mert szignifikánsan javítja az RNS interferencia hatékonyságát. (Dietzl és mtsai. 2007). Mindkét RNS interferenciás vonal használata erős röpképtelen fenotípust eredményezett: a KK102786 kontrukt (RNSi ${ }^{\mathrm{VDRC}}$ ) esetében $94 \%$ míg a $T 129 M\left(\mathrm{RNSi}^{\mathrm{T} 129 \mathrm{M}}\right)$ vonal esetében $87 \%$ volt a röpképtelenek aránya. Végül a dDAAM fehérje szintet tovább csökkentettük az említett módon úgy, hogy $d D A A M^{E x I}$-es háttéren végeztük el az RNS interferenciát (dDAAM ${ }^{E x I}$, UH3-Gal4; UAS-Dicer2; UAS- 
$d D A A M^{R N S i-T 129 M}$, rövidítve: $\left.d D A A M^{E x I}, U D T\right)$. Ebben az esetben a röpképtelen muslicák aránya 98\%-ra emelkedett (14. ábra A). A röpképtelen fenotípus erőssége megegyezett a dDAAM fehérje szintjének az IFM-ben tapasztalt csökkenésével mind a $d D A A M^{E x I}$-es, mind pedig az RNS interferenciás genotípusú állatok esetében (14. ábra B). Western blot analízis segítségével a dDAAM fehérjeszintet vizsgálva az IFM-ben azt találtuk, hogy a dDAAM-nak két izoformája expresszálódik ebben az izomban: egy 130 kDa-os rövid, és egy163kDa méretü hosszú izoforma.

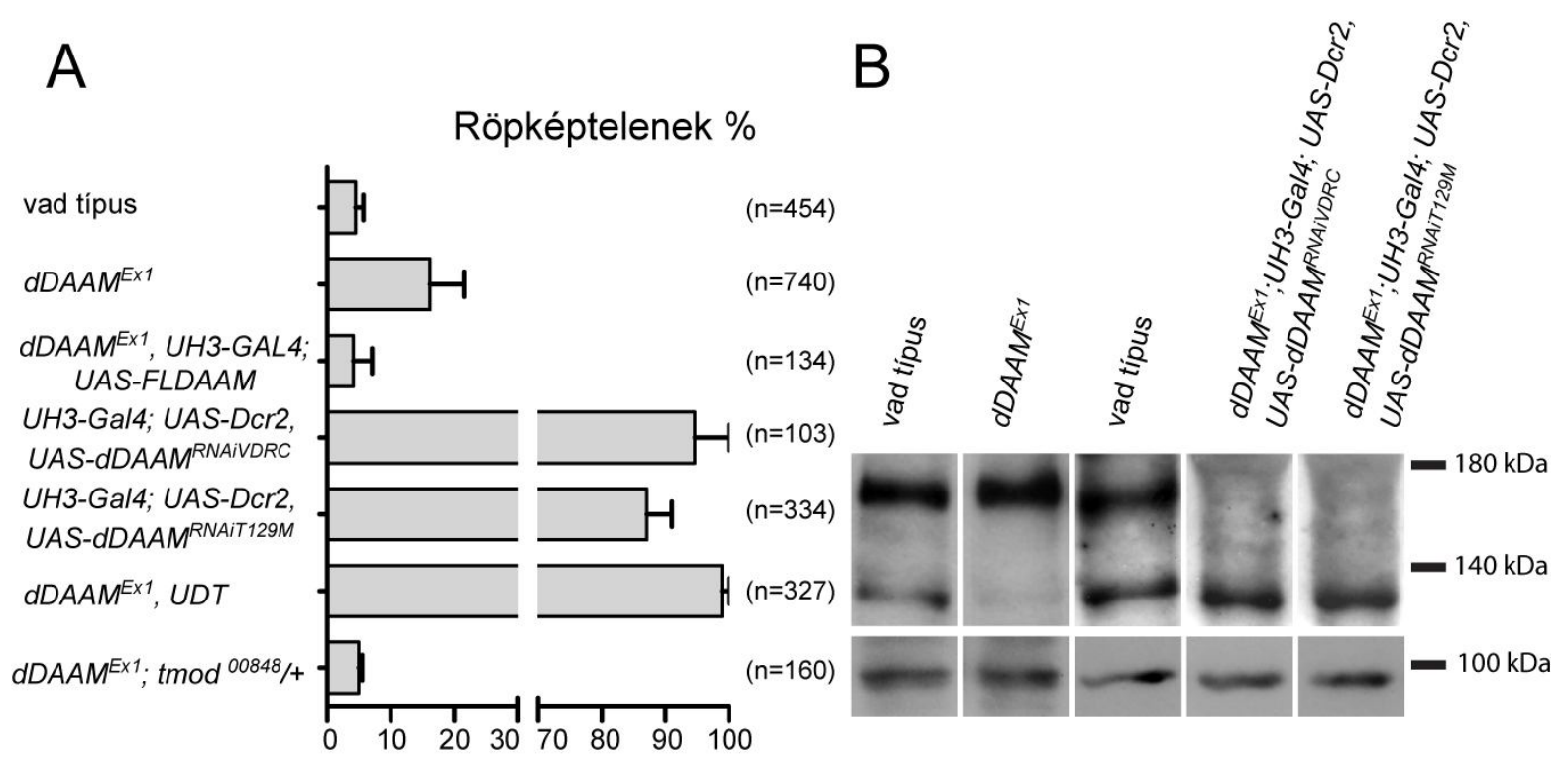

14. ábra A $\boldsymbol{d} \boldsymbol{D} \boldsymbol{A} \boldsymbol{A} \boldsymbol{M}$ befolyásolja a röpképességet. (A) A vad típusú és $d D A A M$ mutáns legyek röpképességének mérése a megfelelő genotípusok feltüntetésével. Az oszlopok az átlagértéket ábrázolják, melyek fölött a szórások értéke található. (B) Western blot analízissel mutattuk ki, hogy a vad típusú IFM-ben kétféle dDAAM izoforma expresszálódik: egy $130 \mathrm{kDa}$ és egy $163 \mathrm{kDa}$ méretü izoforma. A hosszú izoforma nagyobb mennyiségben expresszálódik. A $d D A A M^{E x I}$-es allélben a $130 \mathrm{kDa}$-os rövid izoforma szintje, míg az RNS interferenciás vonalakban a $163 \mathrm{kDa}$-os hosszú izoforma szintje csökken le számottevően. Belsö kontrolként a glikogénfoszforiláz ellenanyagot használtuk $(100 \mathrm{kDa})$.

A rövid izoforma méretben megfelel a Flybase által prediktált PB izoformának, míg a hosszú izoforma a mérete alapján a PD izoformának felel meg. Az 14. ábra B paneljén látható, hogy a PD, hosszú izoforma nagyobb mennyiségben expresszálódik. A $d D A A M^{E x I}$-es allélben a $130 \mathrm{kDa}-\mathrm{os}$ rövid izoforma szintjében mutattunk ki csökkenést, míg az RNS interferenciás vonalak esetében a 163 kDa-os hosszú izoforma szintjében sikerült nagymértékü csökkenést 
kimutatnunk (14. ábra B). A $d D A A M^{E x I}$-es és az RNS interferenciás röpképtelen fenotípust menekíteni tudtuk mind a dDAAM-PB mind pedig a PD izoforma túltermelésével. A röpképtelenek aránya 4\%-ot tett ki a $d D A A M^{E x I}$-es menekített hímek esetében, ami megegyezett a vad típuséval, míg ez az érték a menekített $d D A A M^{E x I}, U D T$ esetében 7\%-os volt. 


\subsubsection{Atomerő-mikroszkópiás mérések az indirekt repülöizom miofibrillumain}

Az atomerő mikroszkóp (ㅅtomic Force Microscope, AFM) alapelve: egy speciálisan kialakított tủ alakú szondát atomi méretü lépésekkel mozgatunk a vizsgált felülettől igen kis távolságra, mintha csak egy miniatürizált lemezjátszótüvel tapogatnánk le a felületet. Egy mechanikus rendszer érzékeli az atomi vonzó és taszító kölcsönhatási eröket, a vele összeköttetésben lévő lézeroptikai rendszer jeleiből pedig rekonstruálható a felület atomi mintázata. Az atomerő-mikroszkóp képalkotása a felületet pásztázó tű és a felület atomjai között fellépő erő mérésén alapul. Az AFM tüjével atomi méretekben módosíthatjuk a felületet. A mechanikus rendszer, ami az atomi eröket érzékeli, arra is használható, hogy mikroszkopikus

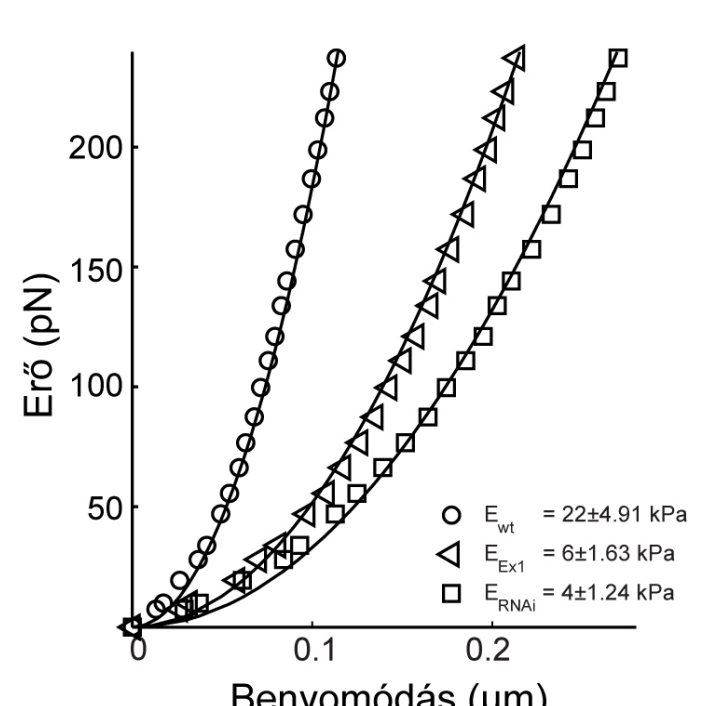

Benyomódás $(\mu \mathrm{m})$ szinten meg tudjuk mérni bizonyos anyagok rugalmasságát (Young modulusát).

Annak érdekében, hogy kiderítsük a $d D A A M$ mutánsokra jellemző szerkezeti hibák befolyásolják-e az izom mechanikai tulajdonságait, olyan AFM elemzéseket végeztünk, amelyek során a miofibrillumok rugalmasságát mértük összehúzódott állapotukban (15. ábra).

15. ábra A vad típusú és $d D A A M$ mutáns miofibrillumok haránt irányú tugalmasságának mérése atomerömikroszkóp segítségével. Hogy a miofibrillumok mechanikai tulajdonságait jellemezni tudjuk, a haránt irányú rugalmasságukat a Young féle modulusz segítségével számoltuk ki. Mintánként a különböző pontokon felvett több erö-benyomódás görbéből számolt átlagot, valamint a standard deviációt ábrázoltuk. A $d D A A M^{E x I}$ és a $d D A A M^{E x I}$,

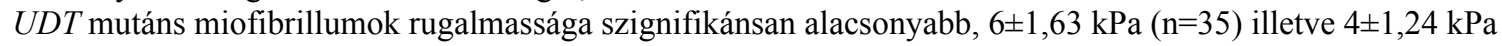
$(\mathrm{n}=15)$, a vad típushoz: $22 \pm 4.91 \mathrm{kPa}(\mathrm{n}=25)$ képest.

A miofibrillumok hosszanti irányú rugalmasságának a mérése adja a legpontosabb képet az izom mechanikai tulajdonságairól, viszont ez a módszer túlságosan idő és munkaigényes, ezen kívül külön felszerelést és szaktudást igényelt volna, ami az adott keretek között nem állt 
rendelkezésünkre. Ezért a technikailag jóval könnyebben kivitelezhető haránt irányú rugalmassági méréseket végeztük el. Ezzel a módszerrel sikerült kimutatnunk, hogy a $d D A A M^{E x I}$ és a $d D A A M^{E x l}, U D T$ mutánsok miofibrillumainak haránt irányú rugalmassága szignifikánsan alacsonyabb a vad típusénál. A Young modulusz értékei a következőek: $6 \pm 1,63 \mathrm{kPa}(\mathrm{n}=35)$ a $d D A A M^{E x l}$-es, $4 \pm 1,24 \mathrm{kPa}(\mathrm{n}=15)$ a $d D A A M^{E x l}$, UDT mutánsok valamint $22 \pm 4,91 \mathrm{kPa}(\mathrm{n}=25)$ a vad típus esetében.

Fontosnak tartom megjegyezni, hogy míg a konfokális mikroszkópiás elemzéssel a $d D A A M^{E x I}$ mutáns IFM csak moderált fenotípusos elváltozást mutatott, addig a rugalmassági mérésekből kitünik, hogy az itt meghatározott érték sokkal közelebb állt a súlyos RNS interferenciás fenotípus esetében mért értékhez, mint a vad típuséhoz. A konfokális adatokat kiegészítve sikerült kimutatni, hogy ha látszólag a szerkezet nem is sokban változott, az még nem jelenti azt, hogy az izom mechanikai tulajdonságai súlyosabban ne károsodtak volna. A fenti eredményeinkből következik, hogy a $d D A A M$ funkció csökkenése maga után vonja az izom szerkezetének és mechanikai tulajdonságainak a gyengülését. Ezek alapján ez a formin típusú fehérje fontos regulátora az izomfejlődésnek, sokoldalúan befolyásolva az ecetmuslicákban a miofibrillum képződést.

\subsubsection{A dDAAM hatással van a lárvális szomatikus izmok és a szivesö fejlödésére}

Az előbbi eredmények után arra a kérdésre szerettünk volna választ találni, hogy a dDAAM fehérjének az IFM fejlődésében betöltött szerepe általánosan érvényes-e minden más típusú izomra is. E célból a lárvális testfal izmokon és a lárvális szíven végeztünk kísérleteket.

\subsubsection{1. $\quad$ A lárvális szomatikus testfal izmok}

Az embrió fejlődésének 13. stádiumában a csírasáv visszahúzódása után egy bonyolult izom mintázat kezd kifejlődni az epidermisz belső oldalán. Ezek az izmok szincíciálisak, 
harántcsíkoltak, és bizonyos helyeken kapcsolódnak a kialakuló lárva testfalához. Mindegyik izom rendkívül egyedi felépítésű, a szomszédjától megkülönböztethető a mérete, alakja, kapcsolódási pontjai és a beidegzése alapján. Habár az izmok mintázata első látásra bonyolultnak tünik (16. ábra A), a mintázat szelvényenként ismétlödő egyszerübb egységekre bontható. $\mathrm{Az}$ A2-A7 abdominális szelvények között egy szabályosan ismétlődő, 30 izomból álló minta látható (16. ábra B, C) (Bate 1990). Az A1-es szelvény egy kissé eltér ettől, mert csak 29 izmot tartalmaz. Az A8-as szelvényben pedig az izmok mintázata különbözik.
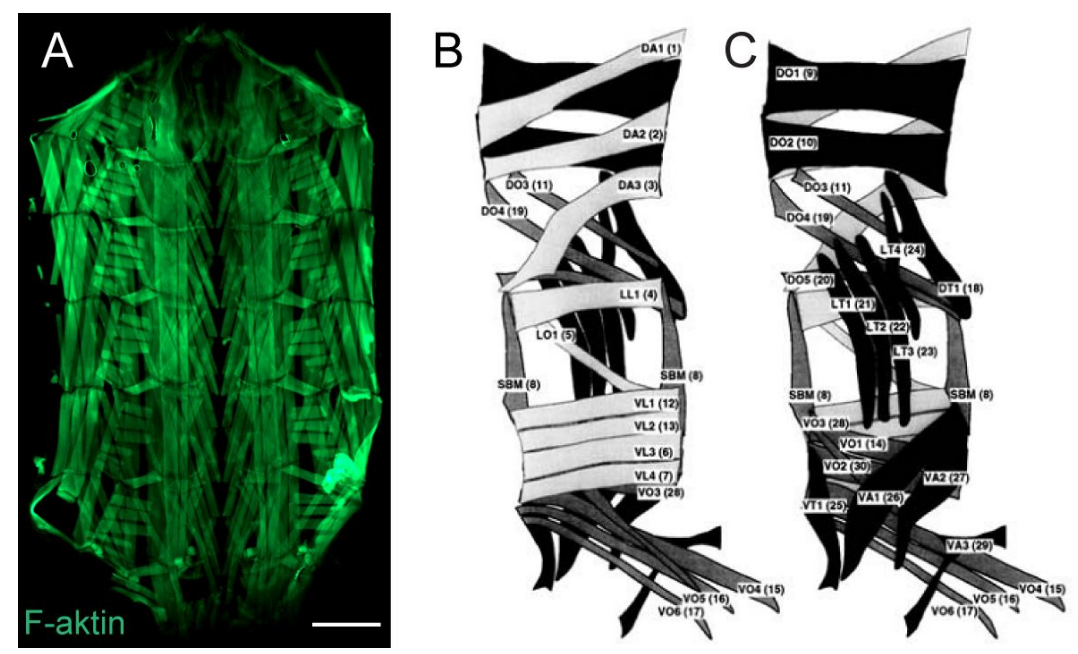

16. ábra A lárvális testfal izmok
mintázata. Az (A) panelen egy L3-
as stádiumú lárva testfal izomzata
látható rodamin-falloidin jelölés
segítségével. Ez a mintázat
szelvényenként ismétlödő
egyszerübb egységekre bontható.
Az abdominális szelvényekben, az
A2-töl az A7-ig, egy szabványos,
30 izomból álló minta látható
belülről (B) és kívúlről (C) nézve.
A felső rész a dorzális résznek, míg
az alsó a ventrális középvonalnak
felel meg. A skála mérete: $250 \mu$ m.
Forrás: Bate 1990.

A megközelítőleg 5 napig tartó lárvális életszakasz során a testfal izmok látványos növekedésen mennek keresztül szarkomerek összeszerelődése és új miofibrillumok hozzáadása által, miközben a sejtmagvaik száma nem változik, bár ezek a sejtmagok DNS replikáción és növekedésen mennek keresztül (Bate és mtsai. 1991; Demontis és Perrimon 2009). A báb metamorfózisának kezdetén a lárvális izmok többsége hisztolízis útján lebomlik mielőtt az adult izmok differenciációja megtörténne, de néhányuk fennmarad, és ezek templátként szolgálnak az adult izmok összeszerelődésénél. Ebben az időszakban alakulnak ki az új adult izmok olyan mioblasztokból, amelyek differenciálatlanok maradtak az embrionális és a lárvális élet során (Currie és Bate 1991). A mioblasztok fúziójának a száma határozza meg a kialakuló izom egyedi 
méretét, míg az izom alakját alapvetően az ínsejtekhez való kapcsolódása szabja meg. Az izmok nem csak ezekhez az ínsejteknek nevezett specializálódott epidermális sejtekhez kapcsolódhatnak, hanem egymáshoz is (Schnorrer és Dickson 2004), így alakítva ki a felnőtt izomzatra jellemző összetett mintázatot.

\subsubsection{A lárvális testfal izmok nevezéktana}

A Bate féle nomenklatúrában az izmokat három fő csoportra osztják: dorzális (dorsal), laterális (lateral) és ventrális (ventral) csoportokra. Ezeken belül az izmok tovább kategorizálhatók irányítottságuk szerint hosszanti (longitudinal), átlós (transverse), ferde (oblique) vagy hegyesszögű irányú (acute) izmokra. A „ferde” és „hegyesszögü” megnevezést annak az elkülönítésére használják, hogy ha az izom iránya a dorzális elülső résztől a ventrális hátulsó rész felé tart akkor „ferde”, míg ha a dorzális hátulsó résztől a ventrális elülső rész felé, akkor „hegyesszögü”irányítottságú. Mindegyik alkategórián belül, mint például „dorzális ferde” izmok, az izmokat a további megkülönböztetés érdekében számozzák is a dorzális résztől a
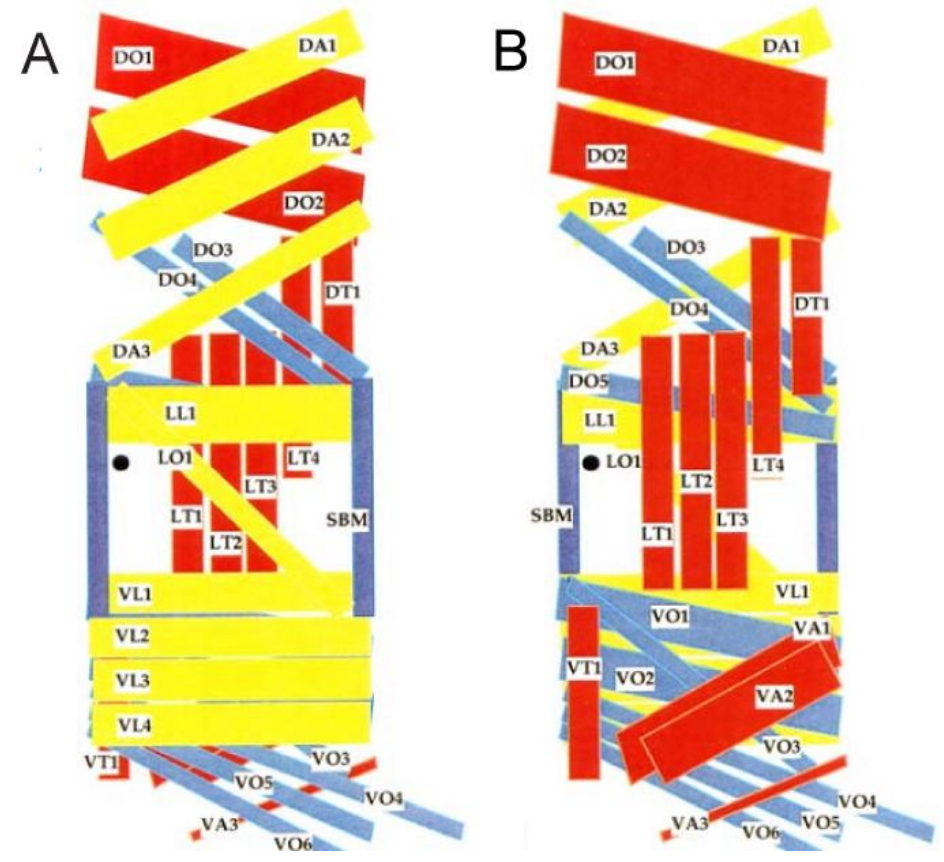
ventrális, valamint az elülső résztől a hátulsó felé (17. ábra) (Bate és Arias 1993).

17. ábra A lárvális testfal izmok nomenklatúrája. Az A2-től az A7-ig tartó abdominális szelvények sematikus ábrája belsö (A) és külső (B) nézetben. A DA rövidítés a ,dorsal acute"-nak, DO a „dorsal oblique"-nek, a DT a ,dorsal transverse”-nek, az LL a , lateral longitudinal"-nak, az LO a „lateral oblique"-nek, az LT a „lateral transverse"-nek, a VA a ,ventral acute"-nak, a VL a ,ventral longitudinal"-nak, a VO a „ventral oblique"-nek, végül az SBM a „segment border muscle"-nek felel meg. Forrás: Bate és Arias 1993. 


\subsubsection{3. $\quad$ dDAAM mutánsokban megváltozik a lárvális testfal izmok szerkezete}

dDAAM mutáns lárvák vizsgálata során azt találtuk, hogy a peterakástól (ㅁfter Egg Laying, AEL) számított 72 órás $d D A A M^{E x 68}$-as null mutáns harmadik stádiumú (L3) lárvák testmérete és szomatikus testfal izomzata a vad típuséhoz hasonló. Azonban egy későbbi időpontban, 100 órával a kikelés után már nagy különbség volt a mutáns és a vad típusú lárvák testmérete között. A mutáns lárvák sokkal rövidebbek $(2,08 \pm 0,31 \mathrm{~mm} ; \mathrm{n}=30)$ voltak a vad típusú lárvák testhosszához $(3,24 \pm 0,25 \mathrm{~mm} ; \mathrm{n}=30)$ képest (20. ábra $\mathbf{A}, \mathbf{E})$. Annak ellenére, hogy a mutáns lárvákban súlyos szerkezeti változásokat a teljes testfal izomzat szintjén nem láttunk, a mutáns izmok kisebb méretüeknek bizonyultak, egyes izomrostokban szakadások voltak megfigyelhetőek, és a miofibrillumok egymáshoz viszonyított elhelyezkedése is sokkal lazább volt, mint a vad típusban (18. ábra B, D).
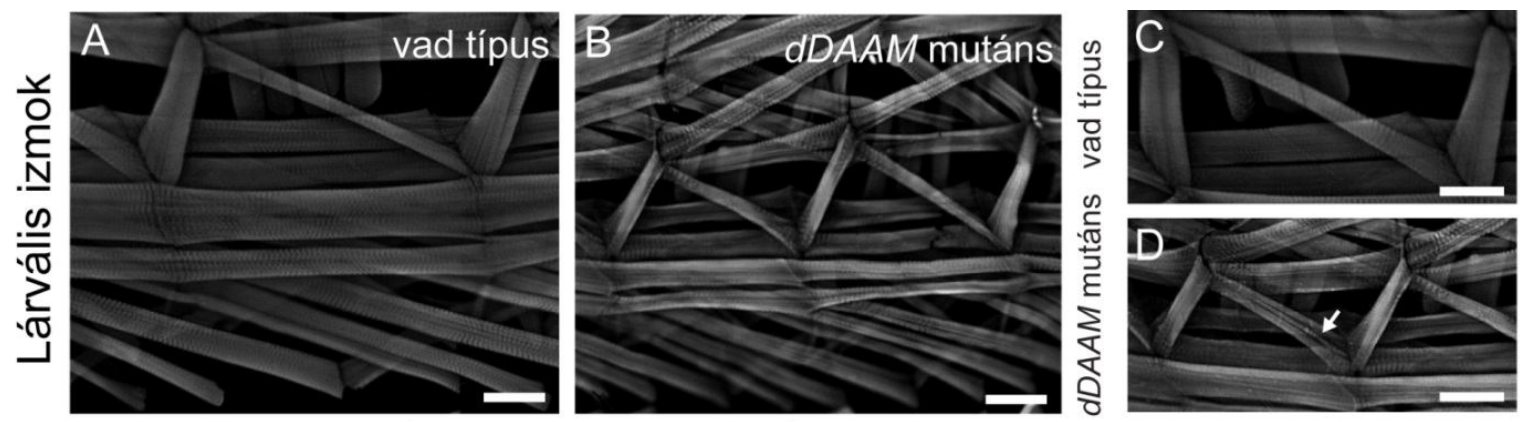

18. ábra A $\boldsymbol{d} \boldsymbol{D} \boldsymbol{A} \boldsymbol{A} M$ mutáns lárvális testfal izmok általános szerkezete. Falloidinnal festett vad típusú $(\mathrm{A}, \mathrm{C})$ és dDAAM ${ }^{\operatorname{Ex68}}$ null mutáns $(\mathrm{B}, \mathrm{D})$ lárvális testfal izmok. A mutáns izmok kisebbek, bizonyos izomrostokban szakadásos rések keletkeztek (a D panelen nyíllal jelöltük), és az általános felépítésüket tekintve az izmok sokkal lazább szerkezetủek a vad típushoz képest. A skála mérete: $100 \mu \mathrm{m}$.

A megfigyeléseink számszerűsítésére kiválasztott 3-as számú ventrális hosszanti testfal izom (VL3) hossza a mutáns lárvákban 53\%-kal, a szélessége pedig 38\%-kal csökkent a vad típushoz képest (20. ábra G, H). A VL3-as izmok $d D A A M$ mutánsokban megfigyelhetö rövidülése két okra vezethető vissza, egyrészt a szarkomer hossz, másrészt a szarkomer szám is csökken ezekben a mutánsokban (20. ábra I, J). Az átlagos szarkomer hossz a vad típusú VL3as izmokban a petéből való kikeléstől számított 100. óra után $6,2 \pm 1,6 \mu \mathrm{m}$ ( $\mathrm{n}=477$ szarkomer), 
ezzel szemben a $d D A A M$ mutánsokban $3,8 \pm 0,7 \mu \mathrm{m}$-re (n=241 szarkomer) csökkent. A $d D A A M$ mutáns esetében a VL3-as izom szarkomer száma is lecsökkent $(30,1 \pm 2,1 ; n=8)$ a vad típushoz $(39,7 \pm 4,3 ; n=12)$ képest.

Ahhoz, hogy ki tudjuk mutatni, hogy az izomszerkezetben bekövetkező defektusok milyen fiziológiai elváltozásokkal járnak, a $d D A A M$ mutáns lárvák mozgásképességét is megvizsgáltuk egy lárvális mászási sebességet mérő tesztben. A strukturális elemzéssel összhangban a 72 órás AEL $d D A A M$ mutáns lárvák egyenes vonalú mászásának a sebessége nem különbözött a vad típusétól (20. ábra B). Ez nagy valószínüséggel az anyai hatásra vezethető vissza, mert a $d D A A M^{E x 68}$-as lárvák $\sim 10 \%$ ában még 100 órával a petéből való kikelés után is kimutatható a fehérje (19. ábra B).
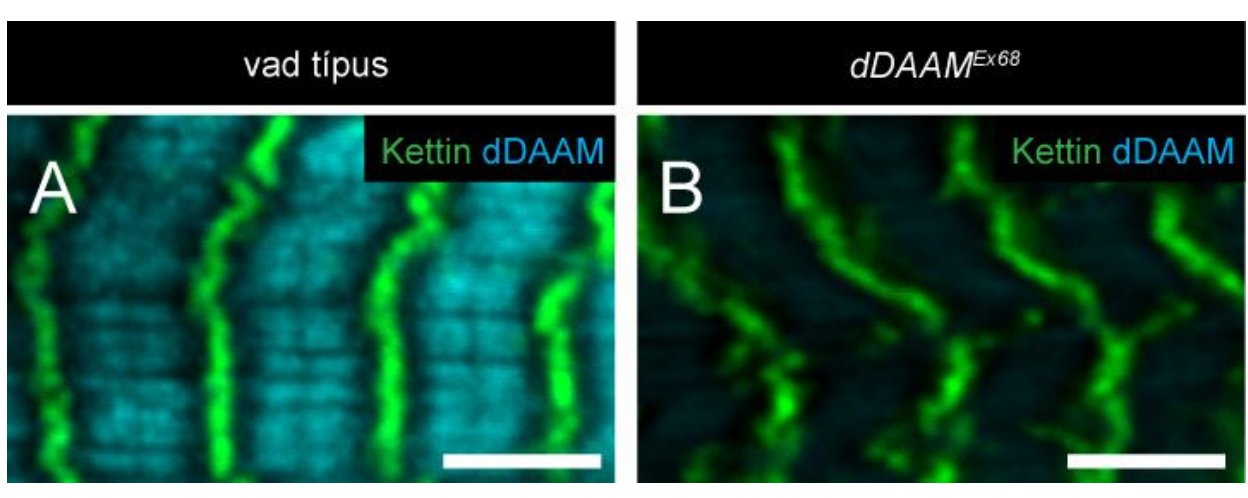

19. ábra A
dDAAM $M^{E x 68}$ mutáns
lárvák egy részében
kimutatható $r$ a
fehérje. (A-B) A
fejlödő vad típusú 72
órás lárvális testfal
izomban (A) jól
látható kettős sávot
alkot a dDAAM
fehérje (ciánkékkel
jelölve). Egy hasonló,
de gyengébb mintázatot figyelhetünk meg a $d D A A M^{E x 68}$-as mutáns lárvák 10\%ában (B). A kettin (zöld) a Z-korongokat jelöli. A skála mérete: $5 \mu \mathrm{m}$.

A 100 órás mutáns lárvák sebessége azonban $\sim 60 \%$-kal csökkent a vad típushoz képest (20. ábra B). Annak ellenére, hogy szoros összefüggés van a lárvák testhossza és mászási sebessége között, a $d D A A M$ mutáns lárvák jóval lassabban mozogtak, mint ahogy csökkent méretük indokolta volna (20. ábra C, D). A menekítési kísérletek, amelyekben az általános izomdriver Dmef2-Gal4 segítségével fejeztettünk ki különböző $U A S-D A A M$ konstrukciókat, igazolták, hogy a megfigyelt fenotípusok a $d D A A M$ funkció hiányának tulajdoníthatóak. 
A fent említett menekítési kísérleteket külön elvégeztük mindkét izoformával. Az UAS$D A A M-P B$ expresszió a $d D A A M^{E x 68}$-as lárvák sebességvesztését csak részben, míg a testhosszát és izomméretét majdnem teljes mértékben menekíteni tudta. Az UAS-DAAM-PD expressziónak pedig sikerült majdnem teljesen helyreállítani a vad típusra jellemző testhossz és sebesség értékeket (20. ábra E-H). Ráadásul a PB és PD izoformák izom-specifikus túltermelése nem csak a lárvális izom károsodásait menekítette, hanem részben képes volt a $d D A A M^{E x 68}$-as null mutáns lárvák életképességét is egészen az adult stádiumig menekíteni (a túlélők aránya a vad típushoz képest 3\% a PB, 6,1\% a PD izoforma által menekített muslicák esetében).

Ezek után a mutáns menekítési kísérleti rendszert felhasználva azt a kérdést vizsgáltuk, hogy a dDAAM fehérje aktin összeszerelö aktivitásának van-e lényeges funkcionális szerepe a fehérje in vivo müködésében. Ezek a kísérletek azt mutatták, hogy a vad típusú konstrukciókkal ellentétben az aktin polimerizálásra képtelen mutáns formák, az $U A S-D A A M-P B^{I 732 A}$ és az $U A S-$ $D A A M-P D^{I 1042 A}$, melyek a Bnil élesztő formin fehérje FH2 doménjét érintő I1431A mutációt utánozzák (Xu és mtsai. 2004), nem menekítették a fenotípust (20. ábra E-J). Sőt, az UAS$D A A M-P D^{I 1042 A}$ mutáns háttéren túltermelve domináns negatív formaként viselkedett a testhossz és a sebesség menekítése esetében. Azaz, a testhossz és sebesség értékei alacsonyabbak voltak a $d D A A M^{E x 68}$-as mutánsénál. Ez valószínűleg azzal magyarázható, hogy a forminok csakis dimerként működőképesek és mind a fehérje N-terminális fele, mind az FH2 domént hordozó Cterminális fele képes dimerizálódni, illetve részt vesz a dimerizációban (Otomo, Tomchick és mtsai. 2005; Rose és mtsai. 2005; Shimada és mtsai. 2004; Xu és mtsai. 2004). Ezek alapján az várható, hogy az aktin polimerizációra képtelen mutáns forma is alkothat dimert egy endogén teljes hosszúságú fehérjével, ami azonban egy inaktív heterodimer lesz, hiszen a formin aktivitás szempontjából esszenciális FH2 dimernek csak az egyik tagja lesz müködőképes. Tekintve, hogy 
ilyen heterodimerek képződése egyben a vad típusú fehérje termék szintjének csökkenéséhez vezet, a domináns negatív hatás érthetővé válik. A fenti adatok tehát azt igazolják, hogy a dDAAM-nak a lárvális izomszerkezet és motilitás kialakításában betöltött szerepe a fehérje aktin összeszerelő aktivitására vezethető vissza. Úgy tünik, hogy a két izom-specifikus dDAAM izoforma, ha nem is teljes egészében, de részben redundáns szerepet játszik a lárvális izmok fejlődésében.

A mutáns háttéren végzett kísérleteken kívül a dDAAM konstrukciók vad típusú genetikai háttéren való túltermelését is elvégeztük. Figyelemre méltó módon az UAS-DAAM-PB és az $U A S-D A A M-P D$ vad háttéren végzett izom-specifikus túltermelése a vad típusú lárvák testhosszánál szignifikánsan hosszabb lárvákat eredményezett. Az UAS-DAAM-PB-vel végzett

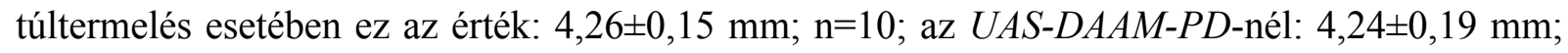
$\mathrm{n}=10$, szemben a vad típusnál mért $3,24 \pm 0,25 \mathrm{~mm} ; \mathrm{n}=30$, értékkel. A túltermelések hatására kimutatható volt a VL3-as izmok meghosszabbodása, annak ellenére is, hogy mindkét esetben kissé rövidebb átlagos szarkomer hosszt mértünk, mint a vad típusnál (20. ábra $\mathbf{E}, \mathbf{G}, \mathbf{I}$ ). Ezeknek az izmoknak a meghosszabbodásához az vezetett, hogy a szarkomerek száma

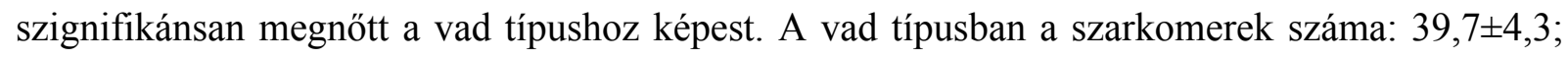
$\mathrm{n}=12$, az $U A S-D A A M-P B$ túltermelésnél $56 \pm 2,8 ; \mathrm{n}=14$, míg az $U A S-D A A M-P D$-nél ez az érték $54 \pm 2,5 ; \mathrm{n}=12$ (20. ábra J). 

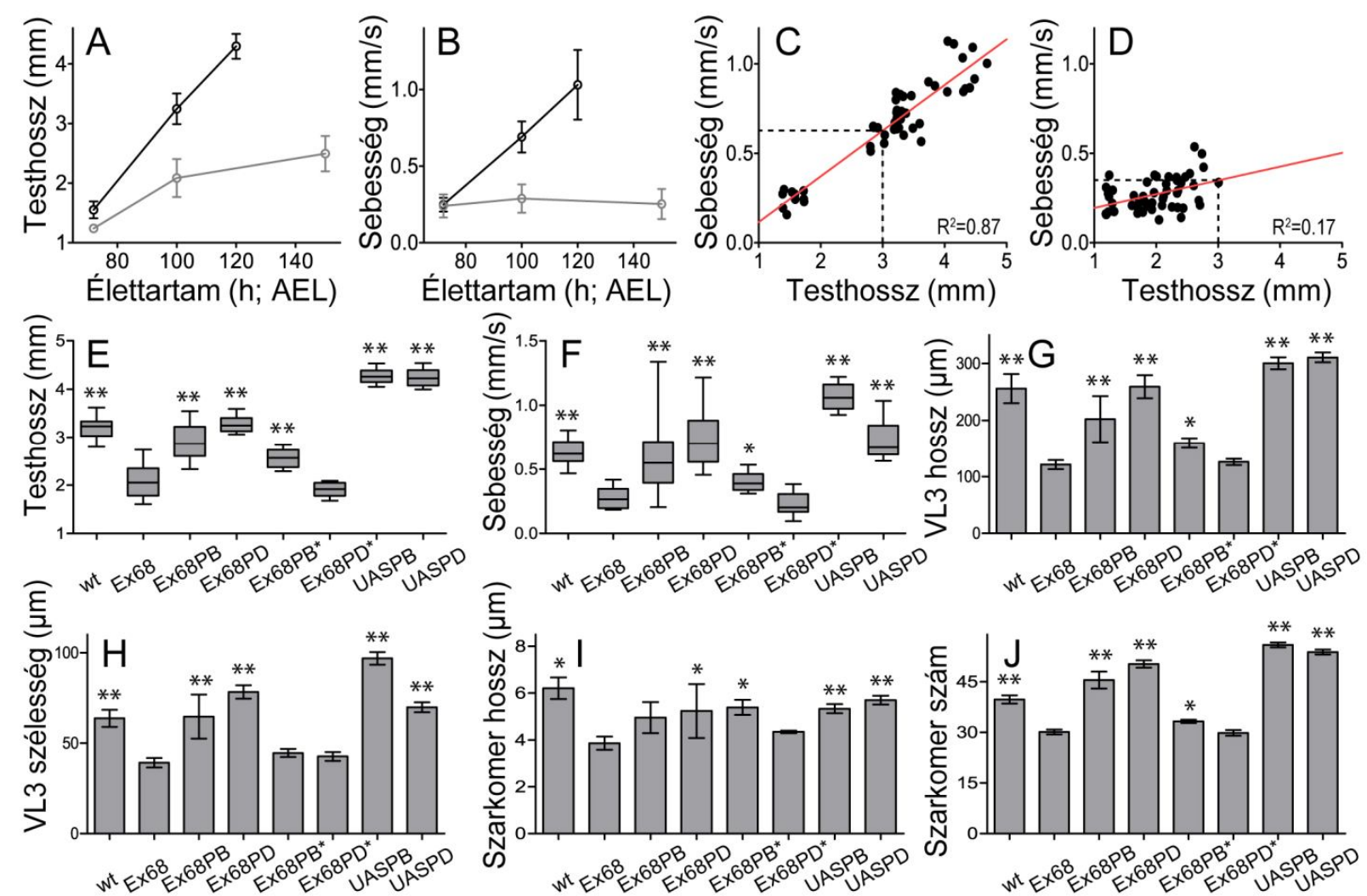

20. ábra A lárvális testfal izmok strukturális és funkcionális analízise. A lárvális életkor és a testhossz közötti összefüggés (A), és a lárvális életkor és mászási sebesség közti összefüggés (B) a vad típusú (fekete vonallal jelölt), és a $d D A A M^{E x 68}$ mutáns (szürke vonallal jelölt), lárvák esetében. A lárvális testhossz és mászási sebesség közötti összefüggés a vad típusú $(\mathrm{C})$, és a $d D A A M^{E x 68}$ mutáns (D) lárvák esetében. A lárvális testhossz (E), mászási sebesség (F), a VL3-as izom hossza (G), szélessége (H), valamint az átlagos szarkomer hossz (I) és az össz szarkomer szám $(\mathrm{J})$ adatainak ábrázolása a 100 órás AEL lárvákban a következő genotípusok szerint: wt (vad típus),

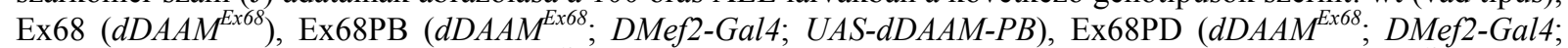
$U A S-d D A A M-P D)$, Ex68PB*(dDAAM ${ }^{E x 68 ;}$ DMef2-Gal4; UAS-dDAAM-PBI732A), Ex68PD* (dDAAM Ex68; DMef2Gal4; UAS-dDAAM-PDI732A), UASPB (DMef2-Gal4; UAS-dDAAM-PB) and UASPD (DMef2-Gal4; UAS$d D A A M-P D)$. Az I-N paneleken az oszlopok átlagértékeket ábrázolnak a szórások feltüntetésével. A statisztikai szignifikancia érték: * esetén $0,05>\mathrm{p}<0,001 ; * *$ esetén $\mathrm{p} \leq 0,001$. A vad típusú és a menekítési kísérletek adatait mindig a $d D A A M^{E x 68}$ mutáns adatokhoz hasonlítottuk, a kivételeket a szövegben jeleztük.

A fent említett strukturális változások tehát majdnem azonosak voltak mindkét izoforma túltermelése esetén. Viszont megemlítendő, hogy míg a PB izoformát túltermelő lárvák sokkal gyorsabban mozogtak ( 55\%-kal gyorsabban) a vad típusú társaiknál (20. ábra F), addig a PD izoformát túltermelő lárvák mozgása csak 5\%-kal volt gyorsabb, tehát szignifikánsan nem különbözött a vad típustól (20. ábra F). Ezen kívül megfigyeltük, hogy annak ellenére, hogy a PB és PD izoformát túltermelő lárvák testhossza nem különbözött lényegesen, a PB-t túltermelő 
lárvák VL3-as izma szignifikánsan szélesebb volt, mint a PD-t túltermelő lárváké. Ezek alapján a dDAAM izoformák szintjének emelkedése önmagában elégségesnek tünik a szarkomer szám megnöveléséhez, de a megfelelő szarkomer hossz eléréséhez szükség lehet a kétféle izoforma közötti együttmüködésre és a kettő közötti arány pontos szabályozására is, ami erősíti azt, hogy csak részben átfedő a funkciójuk.

\subsubsection{A lárvális szívcső szerkezete}

Drosophila lárvákban a gerincesek szívével analóg szerv a szívcső. Ez egy mezodermális sejtekből álló cső alakú képlet, amely dorzálisan az epidermisz középvonala alatt fut az A7-es szelvénytől a fej felé, és a két agyfélteke között ér véget. Az A4/A5-ös szelvényhatártól hátrafele kiszélesedő részt nevezik „,szívnek”, ez a szívcső összehúzódásra képes része (21. ábra). Az A1es és A7-es szelvények között a szívcső kétféle sejtből áll: a kardiális sejtekből, melyek a szívcső belső, izmos falát alkotják, és a hozzájuk csatlakozó külső, perikardiális sejtekből. A

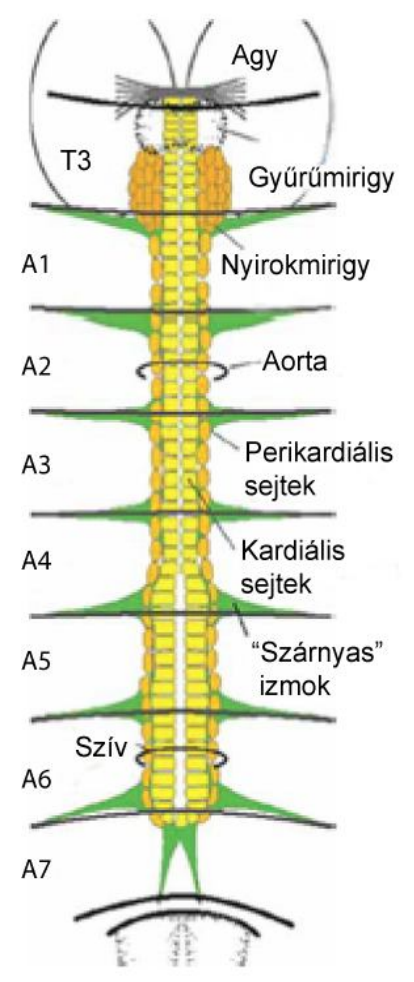
perikardiális sejteket helyhez kötött makrofágoknak tartják (Rizki és Rizki 1978). A lárvális szív falát a testtengelyhez képest spirális lefutású vékony miofibrillumokból álló réteg alkotja. A szívcső falában párosával oldalsó billentyük (ostia) helyezkednek el, melyeken keresztül az elernyedési fázisban a hemolimfa beáramlik. Az A4/A5-ös szelvényhatártól előbbre eső keskenyebb részt aortának hívják. Az aortát a szívtől a kardiovaszkuláris billentyű választja el.

21. ábra A lárvális szívcső szerkezete Ezen a sematikus ábrán látható a szívcső és a hozzá tartozó izmok. Baloldalt a megfelelő szelvények vannak feltüntetve. Forrás: Mandal és mtsai. 2004. 
Ezen kívül, hét pár legyező alakú izom, úgynevezett „szárnyas” izom is kapcsolódik a szívhez. Ezek a szívtől távolodva fokozatosan vékonyodnak és végül az epidermiszben érnek véget. Szerepük a szívnek a lárvális testfalhoz való rögzítése. Kapcsolódási pontjaik a torakális (T) 3tól az A7-esig terjedő részen a szelvényhatároknál találhatók, és egy további izom pár a szív hátulsó végét rögzíti az A7-es szelvény dorzális epidermiszéhez. Az A1-es szelvénytől előbbre az aorta egyszerü csőként folytatódik, és ott nagy valószínüséggel csak kardiális sejtekből áll. Áthalad az agyi komisszúrákon és a gyürümirigytől körülvéve ér véget (21. ábra) (Molina és Cripps 2001; Bate és Arias 1993).

\subsubsection{5. $\quad$ A dDAAM funkcióvesztéses mutáns szivcsö fenotípusa}

A $d D A A M^{E x 68}$ mutánsok lárvális szívcsövének mérete kisebb volt a vad típuséhoz képest ( 40\%-os átmérő csökkenés). A 100 órás vad típúsú lárvákban a szívcső legszélesebb részén mért átmérő: $100,33 \pm 7,39 \mu \mathrm{m} ; \mathrm{n}=9$. Ezzel szemben a $d D A A M^{\text {Ex68 }}$ mutánsokban ez az érték: $60,44 \pm 6,18 \mu \mathrm{m} ; \mathrm{n}=9$, és a szívcső F-aktin szintje is kevesebbnek látszik (22. ábra). Számos mutáns miofibrillum vékonyabbnak tünik a vad típusnál, és az orientációjuk gyakran eltér a
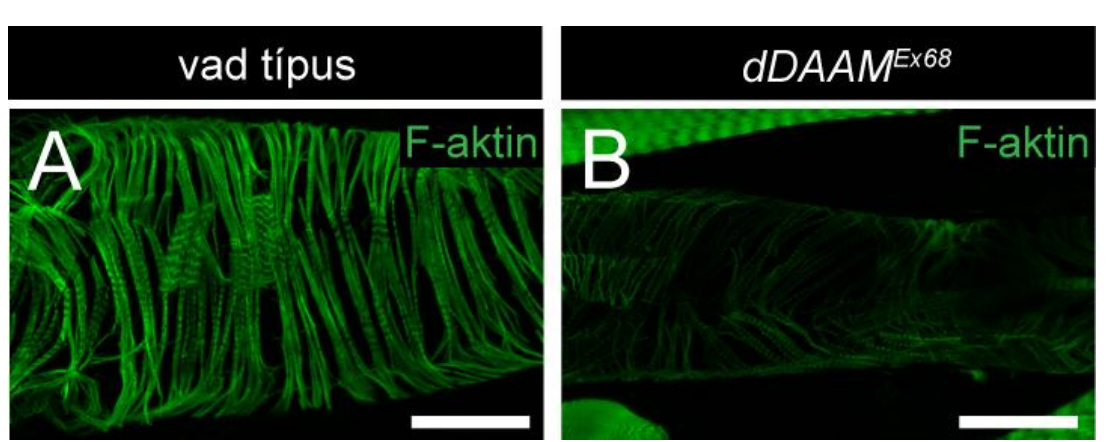
normálistól (22. ábra).

22. ábra $\mathrm{A} d D A A M$ hatással van a szívcső fejlödésére. Vad típusú (A) és $d D A A M^{E x 68}$ mutáns (B) lárvális szívcsövek F-aktin immunhisztokémiai festése rodamin-falloidinnal, (zölddel jelölve). A vad típushoz viszonyítva a $\mathrm{d} D A A M^{E \times 68}$-as mutáns szívesövének átméröje kisebb, F-aktin tartalma kevesebb. Ezenkívül, a mutáns miofibrillumok vad típusú megfelelőiknél vékonyabbnak tünnek és orientációjukban is különböznek. A skála mérete: $40 \mu \mathrm{m}$. 
Ezek a megfigyeléseink azt sugallják, hogy a dDAAM forminnak kulcsszerepe van a Drosophila izomfejlődésében, hatása nem csupán az IFM-re korlátozódik, hanem minden fontosabb izomtípusban és fejlődési stádiumban megnyilvánul.

\subsection{A dDAAM hiányos miofibrillumok vizsgálata}

\subsubsection{A dDAAM hiányos IFM szarkomerikus fenotípusa}

Következő lépésként immunhisztokémiai módszerekkel próbáltuk meghatározni azokat az IFM szerkezetében bekövetkezett változásokat, amik a $d D A A M$ mutánsokban a röpképtelenséget okozhatták. A vad típusú vagy a szülői kontrollként használt UH3-Gal4; UASDicer2 genotípusú állatokban az IFM-ben rendkívül szabályos szarkomer szerkezet figyelhető meg. Immunhisztokémiai festéseknél rodamin-falloidin segítségével az F-aktin kötegeket lehet jelölni, míg Z-korong markerként anti-Kettin ellenanyagot használtunk. A szarkomerek hosszát illetően minden esetben, az állat méretétől függetlenül, 3,2 $\mu$ m-t mértünk az adult legyek IFMjében, hímben és nőstényben egyaránt. A röpképtelen $d D A A M^{E x I}$-es mutánsok IFM-je moderált fenotípust mutatott, ahogyan ez egy gyenge hipomorf alléltól várható. Csak a miofibrillumok $\sim 25 \%$-ban találtunk fenotípust, itt a szarkomerek hossza $\sim 19 \%$-kal volt rövidebb a vad típusál, a miofibrillumok átmérője pedig $\sim 17 \%$-kal volt kisebb (24. ábra $\mathbf{A})$.
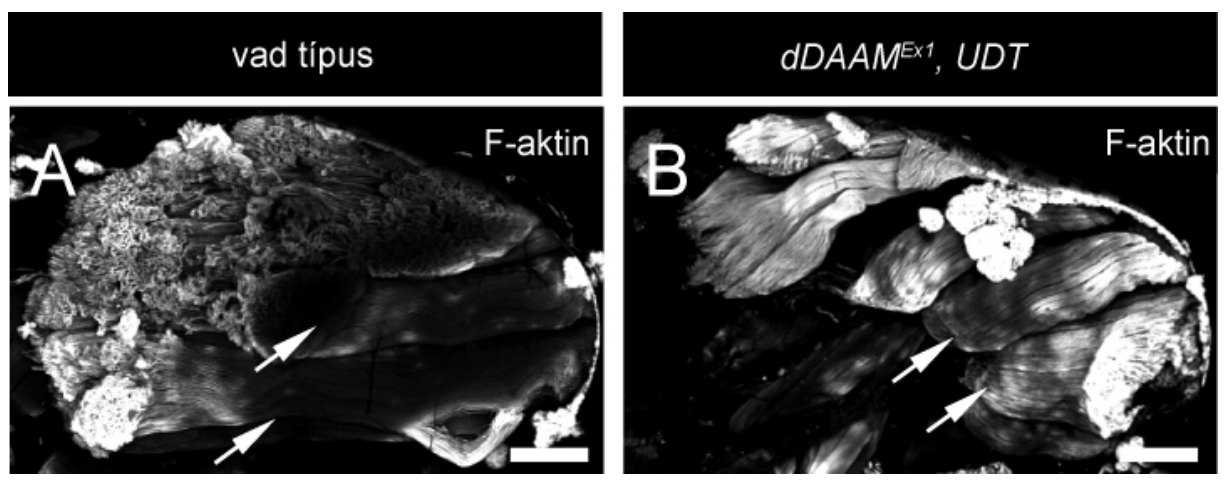

23. ábra $d D A A M$ mutáció hatása az IFM izomrostjainak a morfológiájára. (A-B) Konfokális mikroszkópiás kép az IFM struktúrájáról a vad típusú (A) és dDAAM ${ }^{E x I}, \quad U D T$ mutáns (B) esetében. Ezeknek a szagittális tormetsze-teknek az esetében rodamin-falloidint használtunk az izmok F-aktinjának a jelöléséhez. Megfigyelhető, hogy a mutáns dorzolongitudinális izmok (DLM) rostjai rövidebbek (nyílakkal jelöltük) és vékonyabbak a vad típusnál, és az izmok egy része elsorvadt. A skála mérete: $100 \mu \mathrm{m}$. 
A $d D A A M^{E x I}, U D T$ IFM esetében a fenotípus súlyosbodását figyelhettük meg, kezdve az izomrostok egy részének az elsorvadásával (23. ábra B). A megmaradó miofibrillumok pedig nem csak vékonyabbak a vad típusnál (az átmérő csökkenés eléri a 31\%-ot), hanem a szervezettségüket is elvesztették (24. ábra C-C"; 25. ábra B-C"). Immunfestés alapján az Faktin szint is csökkentnek látszik, viszont a G-aktin mennyiségében nem találtunk változást a vad típushoz képest (24. ábra D). Rodamin-falloidin festés alapján kimutattuk, hogy a vékony (aktin) filamentumok hossza nem egyenletes. A szarkomer hosszának rövidülése ezekben a miofibrilumokban elérheti a 38\%-ot. Az M-vonal nehezen mutatható ki miozin immunfestés segítségével (24. ábra C), míg a Z-korongok szabálytalan és delokalizált festődést mutattak (25.

ábra B-C").
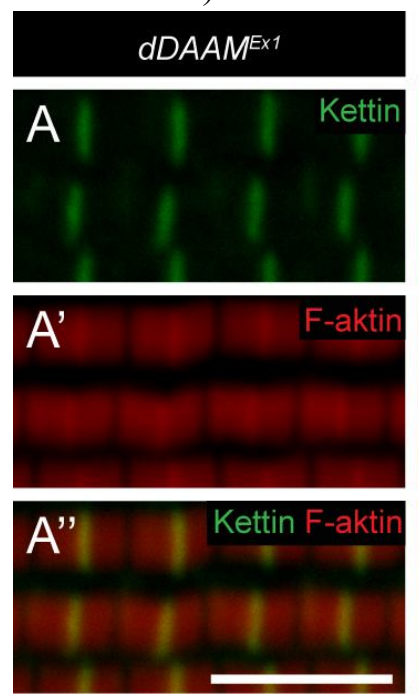
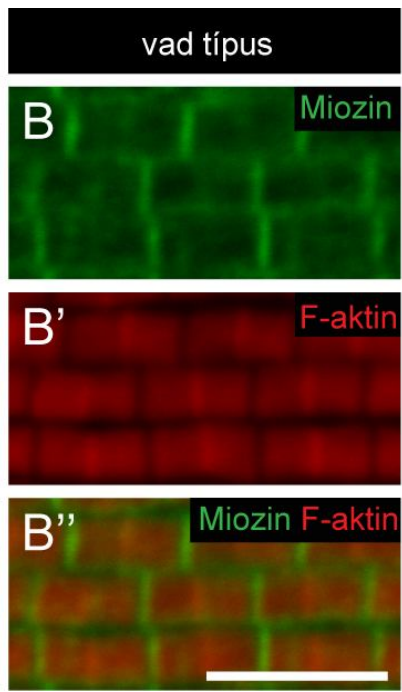
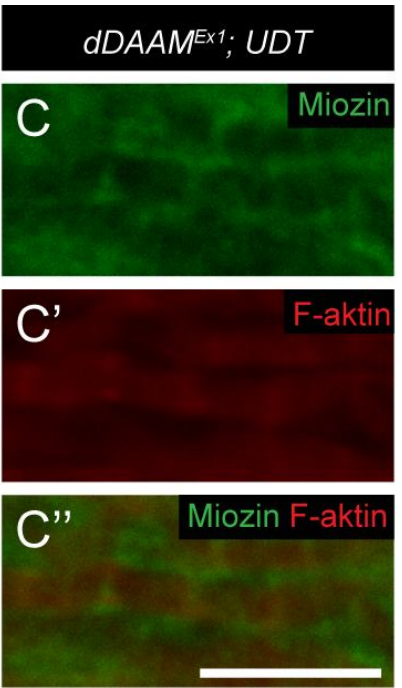

24. ábra A $\boldsymbol{d D} \boldsymbol{A} \boldsymbol{A} M$ mutánsok IFM fenotípus komponensei. (A-A") A röpképtelen $d D A A M^{E x I}$-es mutánsok IFM miofibrillumai nagyjából normálisnak tünnek, csak a szarkomerek egy részének rövidebb a hossza. $(2,5 \mu \mathrm{m}$ a $3,2 \mu \mathrm{m}$ helyett; a kettint zölddel, az aktin pirossal jelöltük). (B-C') Vad típusú (B-B') és a $d D A A M^{E x I}, U D T$ mutáns (C-C') miofibrillumok immunhisztokémiai festése, amelyben a miozint (zöld) és az aktint (piros) jelöltük. A dDAAM mutánsban megfigyelhető a károsodott miozin és M-vonal szerveződés, és a jelentős F-aktin szint csökkenés. (D) Coomassie festéssel nem találtunk különbséget a vad típusú és a $d D A A M^{E x I}$, UDT mutáns IFM-ek Gaktin tartalma között. A skála mérete: $5 \mu \mathrm{m}$.

A bábállapot kialakulásától (ㅁfter Puparium Formation, APF) számított 48 órás $d D A A M^{E x I}, U D T$ mutánsok IFM-jében $\left(29^{\circ} \mathrm{C}\right.$-on $)$ már megfigyelhetőek ugyanazok a fenotípusos elváltozások, amelyeket a fiatal felnőtt állatok esetében tapasztaltunk. (Az UAS/Gal4 rendszer 
hatékonysága hőmérséklet függő, ezért minden RNS interferenciás kísérletet $29^{\circ}$ C-on végeztünk). Látható volt a szabálytalan miofibrillum szerveződés, az M-vonalak hiánya, valamint a Z-korongok rendszertelen elhelyezkedése (25. ábra E-E”).
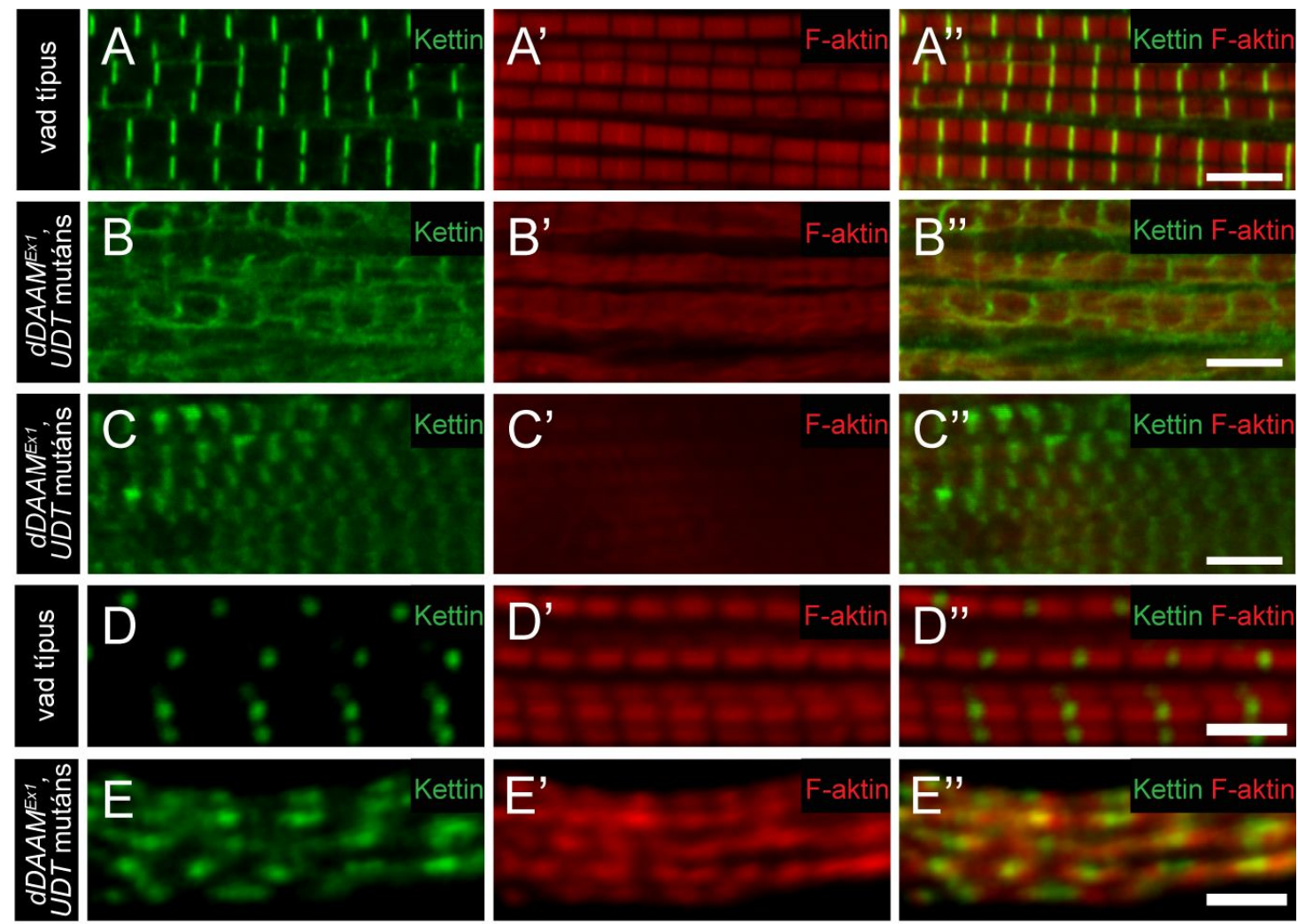

25. ábra További $\boldsymbol{d D A A M}$ mutáns IFM fenokópiák. (A-A") A vad típusú IFM miofibrillumaiban egy rendkívül szabályos szarkomer szerkezet figyelhető meg. (B-C') Két különböző $d D A A M^{E x I}, U D T$ mutáns egyedböl származó miofibrillum fenokópia. Jól láthatóak az összetett szarkomer defektusok (B-C') beleértve a csökkent F-aktin szintet (piros színnel jelölve), a szabálytalan rostvastagságot, kettin ellenanyaggal festett rendezetlen Z-korongok jelenlétét (zölddel jelölve), és a szarkomer hossz csökkenést (C-C"). (D-E") 48 órás bábok IFM miofibrillumai vad típusú (DD”) és $d D A A M^{E x I}, U D T$ mutáns (E-E”) állatok esetében. A mutáns IFM súlyos Z-korong és M-vonal szervezödési hibákat mutat. A skálák mérete: az A-C" paneleken $5 \mu \mathrm{m}$, a D-E" paneleken $2 \mu \mathrm{m}$.

Ezek alapján kijelenthetjük, hogy a dDAAM fehérje hiánya az izomrostok, a miofibrillumok és a szarkomerek szintjén is szerkezetbeli változásokat okoz az izom morfológiájában.

\subsubsection{A dDAAM mutánsok elektronmikroszópos (EM) analízise}

A $d D A A M^{E x l}, U D T$ mutánsok elektronmikroszkópiás analízisével igazoltuk és kiegészítettük a konfokális mikroszkópia által nyert eredményeket. A hosszanti izommetszetek 
elemzésével (26. ábra A-D) olyan vékony, szabálytalan alakú miofibrillumokat tudtunk kimutatni, melyek szélső részei felbomlóban voltak. Emellett a fenotípusos jegyek közül itt is az erős Z-korong defektusok, az M-vonal teljes hiánya, és a megrövidült hosszúságú szarkomerek voltak a legjellemzőbbek. Fontos megfigyelés, és ezt a konfokális mikroszkópiával készült képeken nem láthattuk, hogy a vékony filamentum rendszeren kívül a vastag filamentum rendszer szerveződése is súlyosan érintett. A vastag filamentumok ritkán párhuzamos lefutásúak, és számuk kisebb a vad típushoz képest, ugyanakkor lazább szerveződésüek (26. ábra B, D). Feltünő módon, a vad típusra jellemző váltakozó vastag és vékony filamentumok szabályos elrendeződése helyett (26. ábra A, C), a vastag filamentumok közötti teret több vékony filamentum tölti ki, bizonyos helyeken hálózatot alkotva (26. ábra B, D). Annak ellenére, hogy a mutáns filamentumok szerveződése nagyon különbözik a vad típusétól, méretük alapján rendezetlen vékony (aktin) filamentumoknak tünnek. Egy másik lehetőség szerint, de ennek kisebb a valószínűsége, olyan összekötő filamentumokról lenne szó, amelyek Sallimus/Kettin fehérjét tartalmaznak és a Z-korongokat kötik össze a vastag filamentumokkal a rovar indirekt repülőizomban. Szabálytalan alakú miofibrillumok láthatóak a mutáns IFM-ek keresztmetszeti képén is. A vastag filamentum csoportokat szürke színü anyag veszi körül. Egyedi vékony filamentumok ritkán fordulnak elő (26. ábra H). A vad típusú miofibrillum kristályrácsra emlékeztető szerkezete még nyomokban sem fedezhető fel. Keresztmetszeti képeken a vad típus esetében a vastag filamentumok belseje üregesnek látszik, ez alól csak az M-vonal környéke jelent kivételt, ahol sötét színűek (26. ábra G) (Reedy és mtsai. 1993). Ezzel szemben a dDAAM mutánsban a vastag filamentumok keresztmetszete az esetek többségében nem tünik üregesnek, hanem nagyon sötét színű, és emellett a vad típushoz képest szabálytalan alakú (26. ábra H). A 48 órás mutáns báb izmok EM analízisével is kimutatható volt a szarkomerhossz csökkenés (ami 
elérte a 33\%-os csökkenést a vad típushoz képest), az M-vonal hiány, a rosszul szerveződő filamentumok és a súlyos szerkezetbeli defektus a Z-korongok szintjén (26. ábra J).

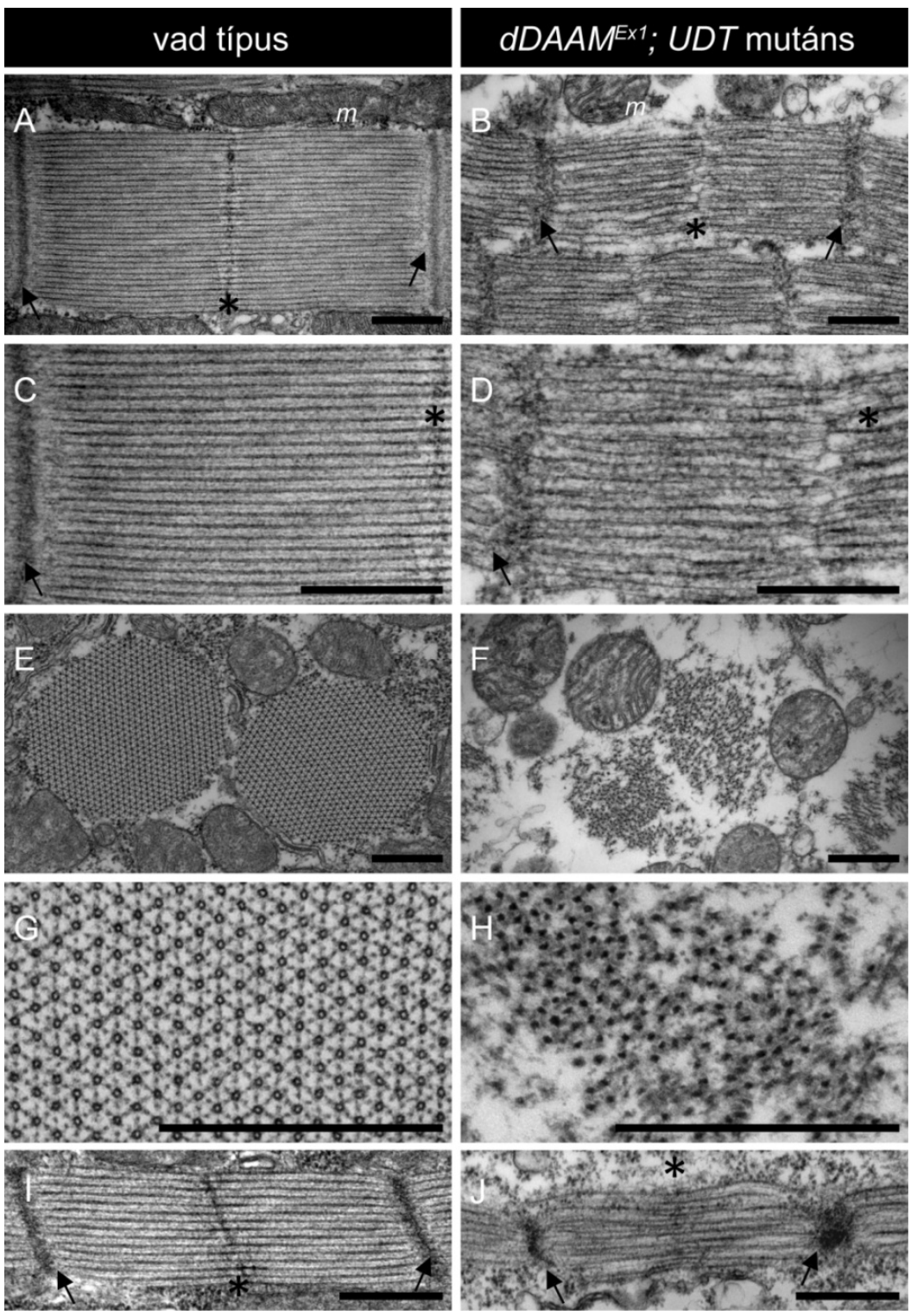

26. ábra A dDaam mutáns IFMek elektronmikroszópos analízise. Vad típusú (A, C, E, G, I) és $d D A A M^{E x I} ;$ UDT mutánsok IFMjeiröl készült elektronmikroszkópos felvételek (B, D, F, H, J). Az adult IFM-ek hosszanti metszeteiröl készült felvételeken látható, hogy a vad típusú (A, C) szigorúan rendezett szarkomer szerkezethez képest a $d D A A M$ mutánsok miofibrillumaiban (B, D) különböző defektusok figyelhetők meg a Zkorongok és M-vonalak szintjén, továbbá a megrövidült szarkomerekben a vékony és vastag filamentumrendszer sokkal lazábban szerveződött. A vad típusú izmok keresztmetszeti képein (E, G) az IFM-re jellemző módon egy vastag filamentumot hexagonálisan 6 vékony filamentum vesz körül. Ez a rendezettség a mutáns miofibrillumokban teljesen megszünt $(\mathrm{F}, \mathrm{H})$. Ehelyett a mutáns rostok szabálytalan alakúak, a vastag filamentumok csoportosulásokat alkotnak, alig fedezhetőek fel egyedi vékony filamentumok. Megjegyzendő, hogy a vad típusú vastag filamentumok belseje üreges (G), míg a $d D A A M$ mutánsoké nagyon sötét színú, szabálytalan alakú, és csak nagyon ritkán üreges belsejű $(H)$. A báb IFM (48 órás APF) hosszanti metszeti képeken (I, J), látható, hogy a vad típushoz képest (I) a mutáns izmokban $(\mathrm{J})$ súlyos Zkorong és M-vonal defektusok, szarkomerhossz rövidülés és szabálytalan filamentum szerveződés van jelen. A képeken nyilakkal jelöltük a Z-korongokat, csillaggal az M-vonalakat, és „m”-el a mitokondriumokat A skála mérete: $500 \mathrm{~nm}$.

Ezek az adatok azt igazolják, hogy a $d D A A M$ mutánsokban tapasztalt izomdefektusok már az izomfejlődés korai szakaszában megjelennek. 


\subsection{A dDAAM fehérje szarkomerikus lokalizációja}

A dDAAM fehérjének a miofibrillumok kialakításában betöltött szerepét tovább jellemezve megvizsgáltuk annak IFM-beli lokalizációs mintázatát. Elsőként frissen kikelt adultok indirekt repülőizmában végeztünk immunhisztokémiai festéseket. A dDAAM-ra specifikus ellenanyag (Matusek és mtsai. 2006) egy erős sávot jelölt az IFM szarkomereinek Mvonalhoz közeli régiójában és egy gyengébb sávot a Z-korong környékén (27. ábra C). (Ezen kívül a dDAAM ellenanyag a szarkolemmát és a sejtmagokat is megjelöli.) Ez a mintázat a legkorábbi vizsgálható időponttól, a bábállapot kialakulása utáni 48 órától egészen a fiatal adult állapotig lényegileg azonos volt (27. ábra A-C). Ugyanakkor az idősödő állatokban az M-vonal környékén a festődés erőssége az idő függvényében fokozatosan csökkent, a Z-korongok környékén viszont erösödött. Ez a tendencia úgy folytatódott, hogy a kikelés után számított negyedik napon az M-vonal és Z-korong környéki sávok erőssége egyformává vált (27. ábra D). A $d D A A M^{E x I}, U D T$ mutánsokban, amelyek közel dDAAM fehérje nullnak tekinthetők (27. ábra E), csak háttérfestődést tudtunk detektálni, ami az ellenanyag specifitását is bizonyítja.

Hogy az immunfestés eredményeit kiegészítsük, egy in situ C-terminálisan EGFP-vel jelölt $d D A A M^{E G F P}$ allélt hoztunk létre. A $d D A A M^{E G F P}$ allél életképes és fertilis homo- és hemizigóta állapotban is, és ennek a fehérjének az expressziója az endogén szabályozó régiók ellenörzése alatt áll. A dDAAM::EGFP fúziós fehérje immunhisztokémiai festése $\alpha$-GFP ellenanyaggal nagyjából hasonló erősségű sávokat mutatott mind az M-vonalak, mind a Zkorongok szintjén a fiatal állatokban, a négy napos állatokban pedig a festődés erőssége csökkent az M-vonalak területén (27. ábra F, G). 
Annak ellenére, hogy az $\alpha$-dDAAM ellenanyag az EGFP ellenanyaghoz képest különbséget mutat a korai és késői dDAAM festődési mintázat között, végső soron kétféle megközelítésben sikerült igazolnunk, hogy a dDAAM fehérje jelen van mindkét helyen: a Zkorongok és az M-vonalak környékén is.
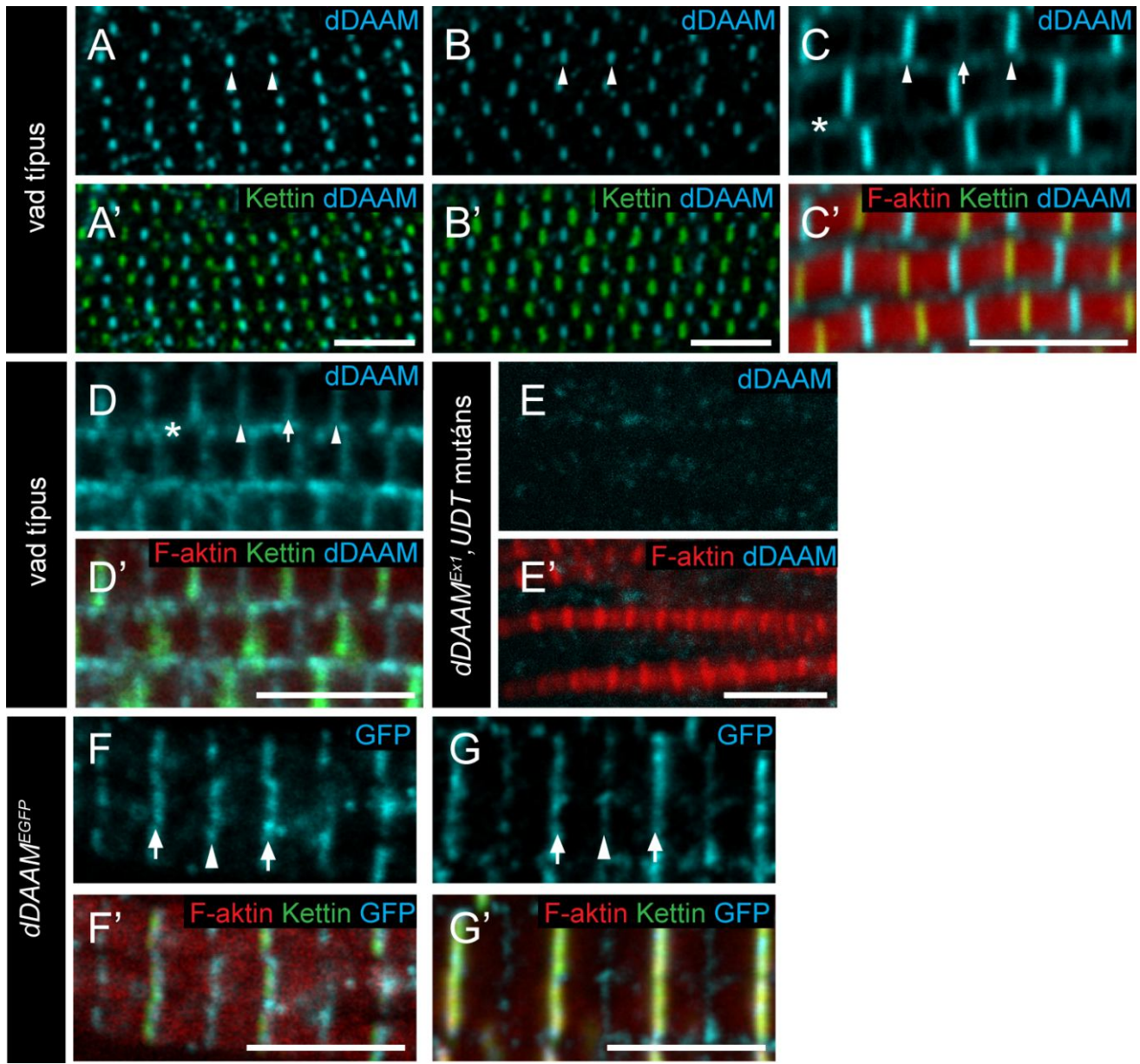

27. ábra A dDAAM fehérje szarkomerikus lokalizációja az IFM-ben. Vad típusú 48 órás (A-A'), 72 órás báb (B-B'), frissen kikelt adultok (C-C') és a 4 napos adultok (D-D') IFM-jeinek dDAAM immunfestése (ciánkékkel jelölve). A dDAAM fehérje az M-vonal (nyílheggyel jelölve) és a Z-korongok közelében (nyíllal jelölve), illetve a szarkoplazmában (csillaggal jelölve) lokalizálódik. Megfigyelhetö, hogy míg a Z-korong közeli felhalmozódás alacsony szintủ a báb és fiatal adultok IFM-jeiben (A-C), addig a 4 napos adultokban a festödés egyforma erősségủ az M-vonalak és az Z-korongok szintjén. Ezzel ellentétben, a $d D A A M^{E x I}$, $U D T$ mutánsok IFM-jeiben csak egy gyenge háttérfestődést detektáltunk (a $D$ és az E panel összehasonlítva). A frissen kelt (F-F') és a 4 napos (G-G') $d D A A M^{E G F P}$ adultokban az anti-GFP egyértelmü festödést mutat a Z-korongok (nyíllal jelölve) és az M-vonal (nyílheggyel jelölve) közelében. A rodamin-falloidin festést pirossal, a Z-korong marker kettint zölddel, az antidDAAM-ot (A-E') és az anti-GFP-t (F-G') ciánkékkel jelöltük. A skála mérete: $5 \mu \mathrm{m}$.

Mivel a vastag és vékony filamentumok a Drosophila IFM esetében szinte teljesen átfednek a szarkomer teljes hosszában, nem tudtuk minden kétséget kizáróan megállapítani, hogy 
a szarkomer közepén megfigyelt dDAAM fehérje feldúsulás M-vonal asszociált, vagy a vékony filamentumok végéhez köthető, amelyek az M-vonalhoz közel érnek véget. Hogy választ tudjunk adni erre a kérdésre, egy olyan kísérleti megközelítést alkalmaztunk, amelyben a Tmod fehérje túltermelésével váltakozó mértékben megrövidült vékony filamentumok képződését idéztük elő az IFM-ben. Az UH3-Gal4/+; UAS-Tmod/+ mutáns legyekben a Tmod fehérjetöbblet meggátolja a vékony filamentumokat a növekedésben, aminek eredményeképpen ezek hossza és illeszkedése sem lesz egyenletes (a végek nem állnak szabályos regiszterben az M-vonal két oldalán) (28. ábra A, B), de az M-vonal szerveződése nem változik számottevően, amint ezt az F-aktin és Obscurin festődésből meg tudjuk ítélni (28. ábra B-B”).
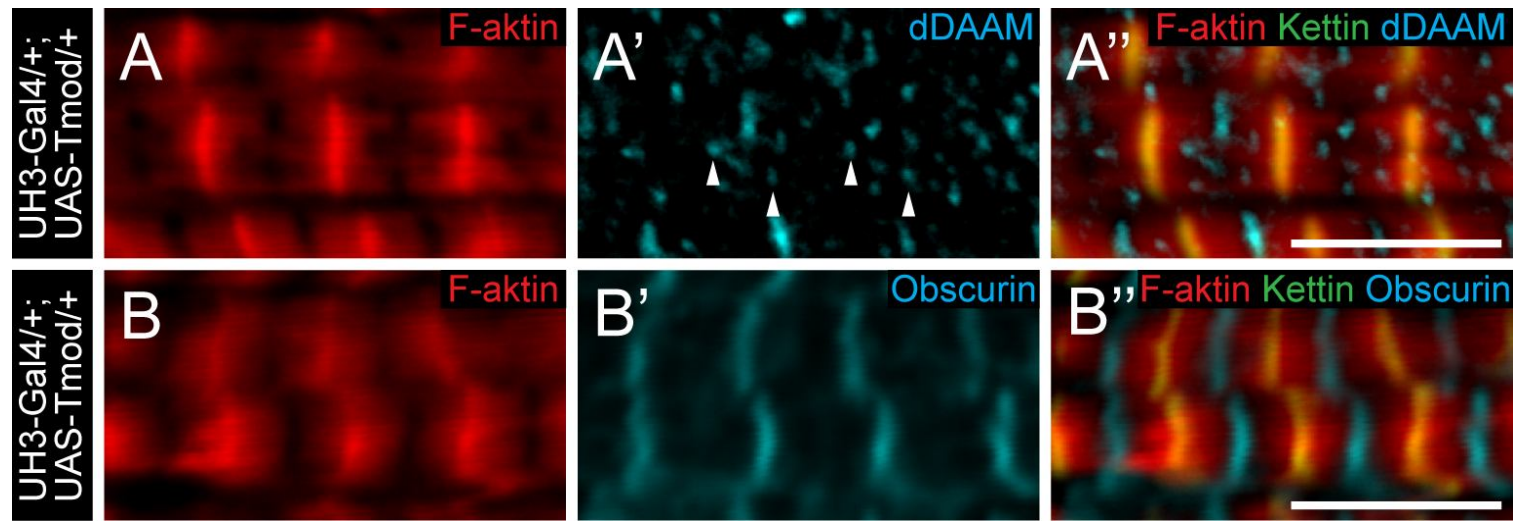

28. ábra A dDAAM fehérje szarkomerikus lokalizációja Tmod túltermelő mutánsok IFM-jeiben. A Tropomodulin fehérje túltermelése az UH3-Gal4/+; UAS-Tmod/+ genotípusú legyekben a vékony filamentumok megrövidülését eredményezte, melyek hossza nem egyenletes, és az illeszkedésük sem megfelelö, ahogy erre az Faktin festésből következtetni lehet (A, B). Ezekben az IFM-ekben a dDAAM festődés pontozott eloszlást mutat (nyílheggyel jelölve az "A" panelen), amelyek többsége a vékony filamentumok mínusz végeivel kolokalizálnak (A”). Ezekben a mutánsokban az M-vonal majdnem teljesen épnek tünik, amennyire azt az Obscurin festés alapján meg tudtuk becsülni (B'). A rodamin-falloidin festést pirossal, az anti-dDAAM-ot (A'-A') és az anti-Obscurin-t (B’-B”) ciánkékkel jelöltük. A skála mérete: $5 \mu \mathrm{m}$.

Ezekben a mutáns IFM-ekben a dDAAM fehérje eloszlása teljesen különbözik a vad típusútól és már nem alkot szabályos alakú sávot az M-vonal közelében. Ehelyett pontozott eloszlású festődést figyelhettünk meg, ahol a dDAAM fehérjét jelölő pontok a vékony filamentumok végeivel kolokalizáltak (28. ábra A”). Ez arra utal, hogy a vad típusra jellemző 
szarkomer középi dDAAM fehérje feldúsulás nagy valószínűséggel az aktin filamentumokhoz való asszociációt és nem az M-vonalhoz való kötődést jelzi.

Az előző konklúzióval összhangban, a fejlődő lárvális testfal izmokban (72 órával AEL után) a dDAAM fehérje két különálló sávba tömörül az M-vonal két oldalán (29. ábra A). Érdekes módon, a kifejlődött lárvális miofibrillumokban viszont a dDAAM fehérje legnagyobb mennyiségben már a Z-korong környékén mutatható ki (29. ábra B). Ennek a mintázatbeli változásnak a biológiai jelentősége egyelőre nem világos, de figyelemreméltó, hogy két másik izomfehérje, a SALS és a Tmod is hasonló kifejeződési mintát mutat (Bai és mtsai. 2007).
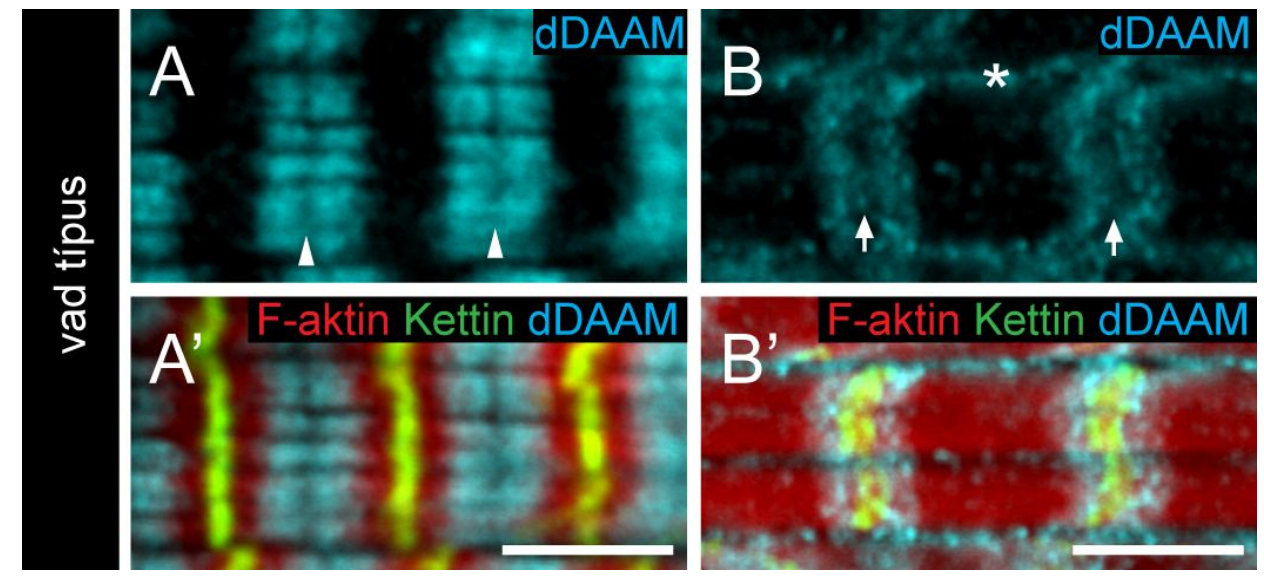

29. ábra A dDAAM

fehérje lokalizációja a lárvális testfal izmokban. A fejlődő lárvális testfal izmokban (72 h AEL), a dDAAM festődés két sávra különül el az M-vonal két oldalán (nyílheggyel jelölve az A-A' paneleken). A teljesen kifejlett lárvális testfal izmokban a dDAAM festődés áttevődik a Z-korongok környékére (nyílvesszővel jelölve a B-B' paneleken). Csillaggal jelöltük a miofibrillumok közötti tér festődését. A skála mérete: $5 \mu \mathrm{m}$.

A lokalizációs adatok azt jelezték, hogy a dDAAM fehérje a növekvő szarkomerekben olyan mintát mutat, amely teljes összhangban van a vékony filamentumok szabályozásában betöltött szerepével.

\subsection{A dDAAM fehérje kölcsönhat a vékony filamentum mutánsokkal}

Hogy további bizonyítékokkal szolgáljunk arra nézve, hogy a $d D A A M$-nak fontos szerepe van a vékony filamentum rendszer kialakításában és szabályozásában, genetikai interakciós kísérleteket végeztünk az IFM specifikus aktin $\left(A c t 88 F^{K M 88}\right)$ és az izom specifikus Tropomiozin $\left(T m 2^{3}\right)$ mutánsokkal (Karlik és Fyrberg 1985; Okamoto és mtsai. 1986). Az IFM szerkezetét 
heterozigótákban vizsgáltuk vad típusú és $d D A A M^{E x I}$ mutáns háttéren. Az eredményekből kitünik, hogy az egyébként gyenge hipomorf $d D A A M^{E x I}$-es IFM fenotípust (30. ábra A) nagymértékben súlyosbítják az $A c t 88 F^{K M 88}$ és $T m 2^{3}$ mutációk.
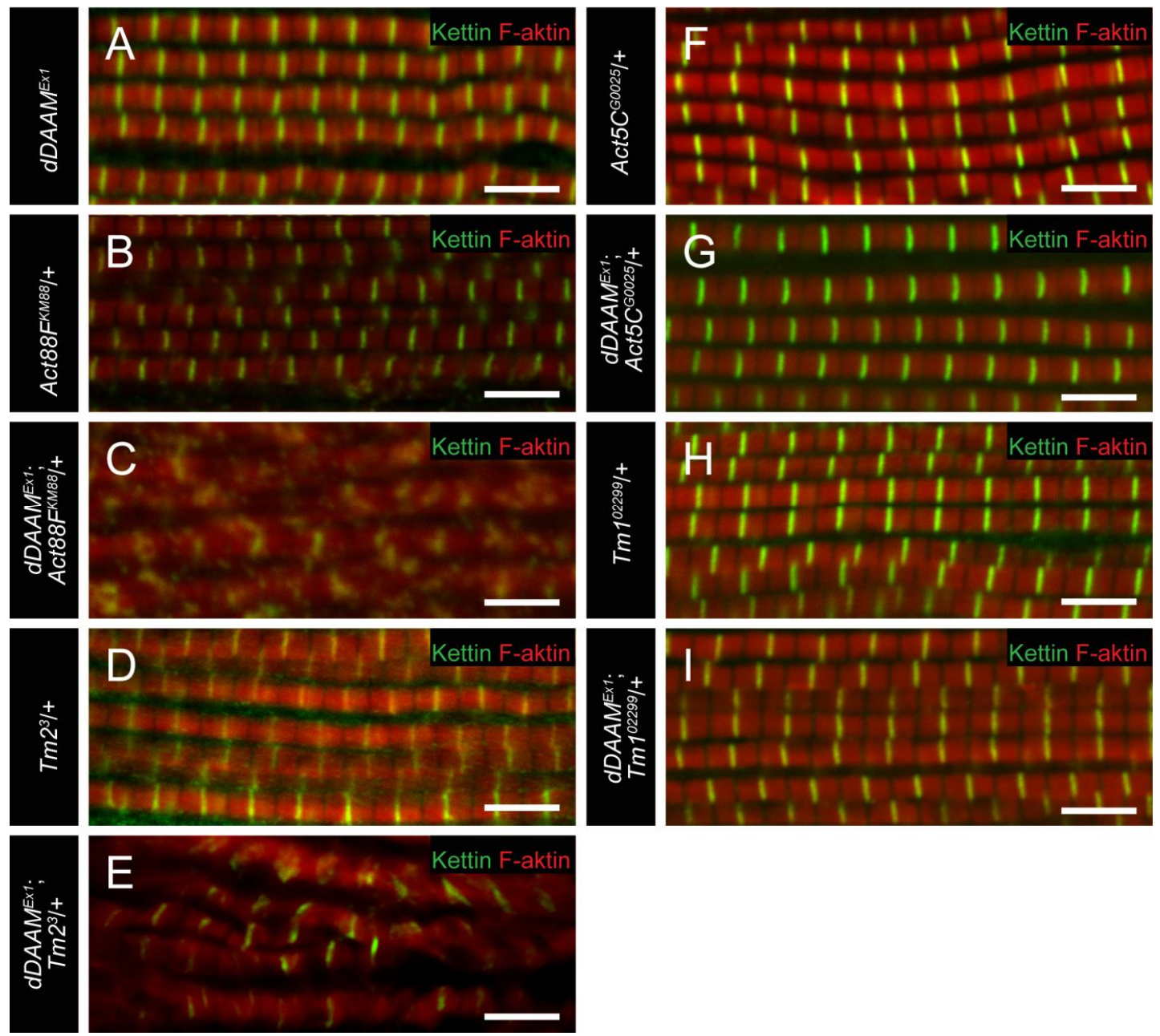

30. ábra A dDAAM kölcsönhat a vékony filamentum mutánsokkal. (A) $d D A A M^{E x I}$, (B) $A c t 88 F^{K M 88} /+$, (C) $d D A A M^{E x I} ; A c t 88 F^{K M 88} /+$, (D) $T m 2^{3} /+$ and (E) $d D A A M^{E x I} ; T m 2^{3} /+$ legyekböl származó IFM miofibrillumok (az aktin pirossal, a kettin zölddel jelölt minden panelen). Megfigyelhetö, hogy a szarkomer szervezettség a $d D A A M^{E x I}$ (A) állatokban a vad típushoz hasonló; ugyanígy az $A c t 88 F$ (B) és a $\operatorname{Tm} 2$ (D) heterozigótákban a miofibrillumok és a Z-korongok szabályos elrendeződésüek. Ezzel szemben a $d D A A M^{E x I} ; A c t 88 F^{K M 88} /+(\mathrm{C}), d D A A M^{E x I} ; T m 2^{3} /+$ (E) genotípusú legyek miofibrillumai rendkívül szervezetlenek. A kontrollként használt kísérletekben pedig az $A c t 5 C^{G 0025} /+(\mathrm{F}), d D A A M^{E x I} ; A c t 5 C^{G 0025} /+(\mathrm{G}), T m 1^{02299} /+(\mathrm{H})$, és a $d D A A M^{E x I} ; T m 1^{02299} /+$ (I), mutánsok miofibrillumai a vad típushoz hasonló szervezettséget mutattak. A skála mérete: $5 \mu \mathrm{m}$.

Az Act $88 F^{K M 88}$ heterozigóták miofibrillumai vékonyabbak a vad típusénál, és néhány Z-

korong nem egyenletes alakú (30. ábra B), de egyébként a szarkomer szerkezet rendezettsége fennmaradt. Ezzel szemben, a $d D A A M^{E x l} ; A c t 88 F^{K M 88} /+$ kettős mutánsban egy szerteágazó 
vékony miofibrillum hálózat figyelhető meg, amelyben a Z-korongok és a szarkomerek rendezett szerkezete teljesen megszünik (30. ábra C). Hasonló módon, a $d D A A M^{E x I}$ hemizigóta; $\operatorname{Tm} 2^{3} /+$ kettős mutánsokban a miofibrillumok szervezetlenek, a vastagságuk nem egyenletes, a szarkomerek és a vékony filamentumok hossza sem egyenletes és gyakori a nagyon rövid szarkomerek megjelenése (30. ábra E). Kontrollként az egyik legfontosabb nem-izom sejt specifikus aktin izoformának, az Act5C-nek a null mutáns formáját használtuk, a G0025-ös allélt (Fyrberg és mtsai. 1983), és a citoplazmatikus Tropomiozin (Tm1) izoforma egy erös funkcióvesztéses alléljét, a $\operatorname{Tm} 1^{02299}$-et (Tetzlaff és mtsai. 1996). Az elvárt módon, ezek a mutációk nem súlyosbították a $d D A A M^{E x I}$ IFM fenotípusát (30. ábra G, I).

Az erős genetikai kölcsönhatás a $d D A A M$ és az IFM specifikus $A c t 88 F^{K M 88}$ és $T m 2^{3}$ allélok között, valamint az interakció teljes hiánya a nem-izom típusú izoformákkal azt jelzi, hogy a dDAAM fehérje funkciója az izomfejlődés során valóban a szarkomerikus aktin filamentumok kialakításához kötődik.

\subsection{A dDAAM fehérje szükséges a vékony filamentumok növekedéséhez}

In vitro körülmények között a dDAAM fehérje FH2 vagy FH1-FH2 doménjei bona fide forminként viselkednek, vagyis rendelkeznek aktin nukleáló és a filamentumok elongációját elősegítő képességgel (Barkó és mtsai. 2010). Az a megfigyelésünk, hogy a vékony filamentumok rövidebbek a $d D A A M$ mutánsokban mint a vad típusban, arra enged következtetni, hogy a dDAAM pozitív regulátora a vékony filamentum növekedésnek. Az irodalmi adatokkal összhangban, miszerint a vékony filamentumok a mínusz vég felöl növekednek, a dDAAM jelen van a vékony filamentumok mínusz végeinek a közelében, vagyis az M-vonal környékén. Másrészt, egy formintól elvárt módon a plusz végek közelében is felhalmozódik. Ahhoz, hogy kiderítsük, hogy a dDAAM fehérjének van-e szerepe a vékony filamentumok mínusz vég felöli 
növekedésében, genetikai interakciós kísérleteket végeztünk két bizonyítottan mínusz vég szabályozó fehérje mutáns alléljaival, a SALS-szal és a Tmod-dal.

A SALS fehérje in vivo körülmények között elösegíti (Bai és mtsai. 2007), míg a Tmod kötődés megakadályozza a v;kony filamentumok elongációját (Littlefield és Fowler 2008). A sals $^{f 07849} /+\mathrm{a} d D A A M^{E x I}$-es mutáns háttéren nem okozott fenotípusbeli változást. Ezzel szemben a $\operatorname{tmod}^{00848}$ mutáció teljes mértékben szupresszálta a $d D A A M^{E x I}$ mutáns gyenge röpképtelen fenotípusát, visszaállítva a vad típushoz közeli értéket $(4,9 \%, n=160$; a vad típus esetében: 4,5\%, n=454), (14. ábra A). Ez arra utal, hogy a filamentum növekedés során a dDAAM és a Tmod müködésüket tekintve antagonisztikus kapcsolatban lehetnek egymással.

Hogy részletesebben elemezni tudjuk a dDAAM/Tmod kölcsönhatást, elöször a Tmod IFM-specifikus RNS interferenciás csendesítését vizsgáltuk. Azt találtuk, hogy az izomrostok többségében a miofibrillogenezis súlyos zavart szenvedett (31. ábra A-B”), de a miofibrillumok hozzávetöleg 10\%ában felismerhető volt a Z-korongok jelenléte. Itt elvégezhettük a szarkomer hossz méréseket, és kimutattuk, hogy a tmod csendesítése a szarkomer hossz 18\%-os csökkenését $(2.62 \pm 0.11 \mu \mathrm{m} ; \mathrm{n}=26)$ eredményezi a vad típushoz képest. Ezen kívül a szarkomerek középső régiójában - ahol normális esetben aktin nem fordul elő - vékony filamentumok jelenlétét mutattuk ki falloidin festés és EM analízis segítségével (31. ábra B', D). Továbbá, az EM analízis segítségével az M-vonal szerkezetében beállt károsodásokat is meg tudtunk figyelni.

A miofibrillogenezisre gyakorolt erős hatás összhangban van az előzetes irodalmi adatokkal, melyekben kimutatták, hogy az egér Tmod1 és a C. elegans Unc-94 (tmd-1) Tropomodulin ortológok szükségesek a szarkomer összeszerelődéshez (Fritz-Six és mtsai. 2003; McKeown és mtsai. 2008; Stevenson és mtsai.2007; Yamashiro és mtsai. 2008). Viszont a szarkomer hossz csökkenés meglepő eredménynek számít, mivel elözetes adatok alapján a Tmod 
funkció gátlása meghosszabbodott szarkomereket eredményezett kardiomiocita sejttenyészetekben (Sussman és mtsai. 1998), illetve Drosophila primer izomsejt kultúrákban (Bai és mtsai. 2007). Megjegyzendő azonban, hogy bár az UH3-Gal4; UAS-tmod ${ }^{R N S i}$ legyek indirekt repülőizmában a szarkomer hossz rövidebb volt a vad típusénál, a vékony filamentumoknak egy része jól látható módon áthaladt a H-zóna határain (31. ábra D). Ennélfogva, az egyedi vékony filamentumok mérete hosszabb is lehet a vad típusénál, ez pedig összhangban van a Tmod ismert vékony filamentum hossz szabályozó szerepével.
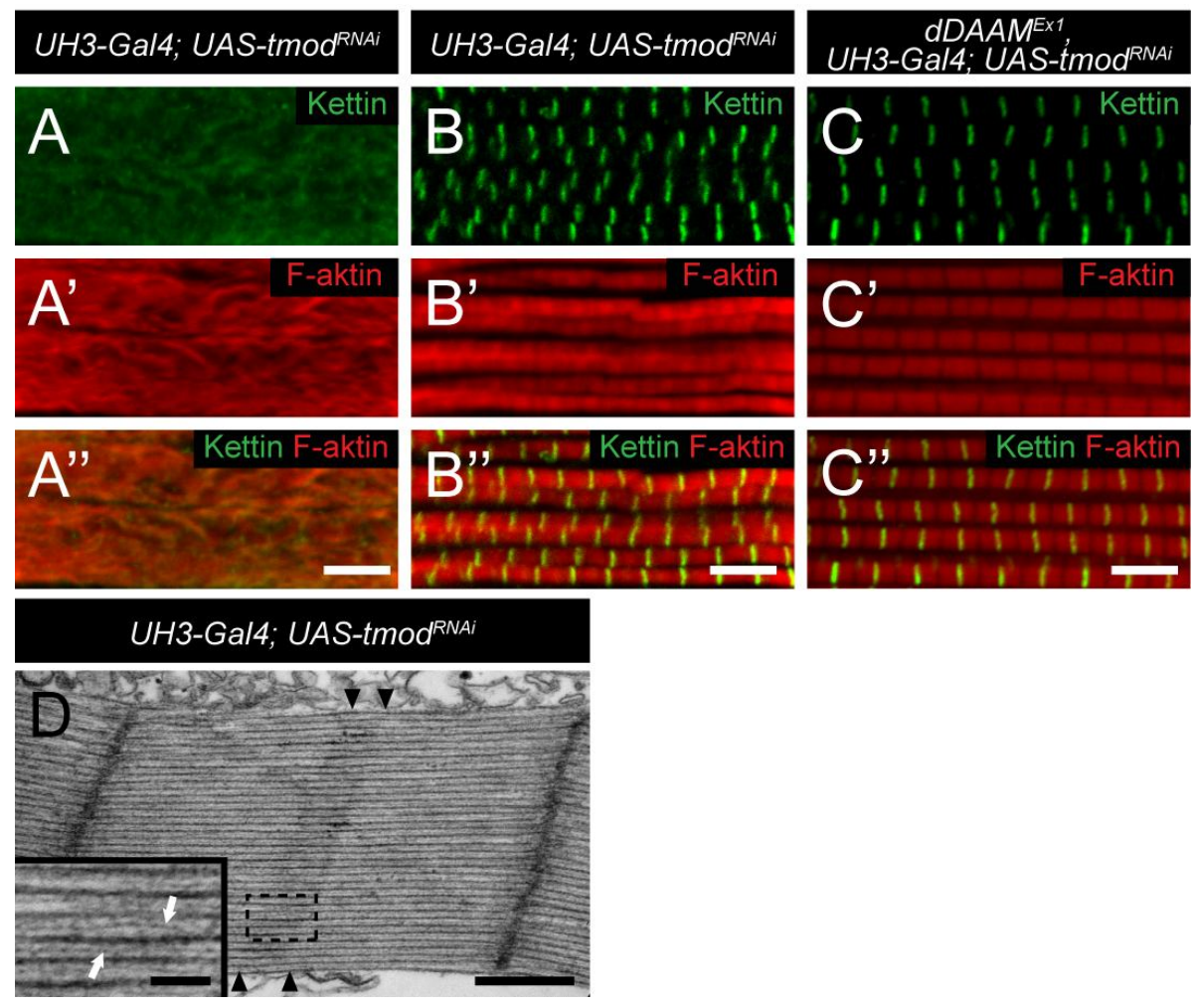

31. ábra A dDAAM és tmod közötti kölcsönhatás. A tmod csendesítése súlyos szarkomer szervezödési rendellenességeket okozott (A-A"), habár a miofibrillumok 10\%-ban az RNSi fenokópia gyengébb volt, itt felismerhetőek voltak a Z-korongok, viszont hiányzott a H-zóna (B-B”). A $d D A A M^{E x I}$,UH3-Gal4; UAS-tmod ${ }^{R N A i}$ legyek izmaiban a miofibrillumok többségének vad típusú volt a szarkomer szerveződése, egymástól szabályos távolságra levő Z-korongokkal és M-vonalakkal, és majdnem normális szarkomer hosszal (C-C"). (D) A tmod ${ }^{R N S i}$ IFM elektronmikroszkópos felvétele. Fekete nyílhegyekkel jelöltük a szarkomer közepének azt a részét, ahol az Mvonal struktúrák nem nyilvánvalóak, de úgy tünik, hogy a vékony filamentumok áthaladnak ezen a részen, a szaggatott vonalú négyszögnek megfelelő nagyított felvételen. Fehér nyilakkal jelöltük azokat a vékony filamentumokat, amelyek nem érnek véget a H-zónában. A skála mérete: $5 \mu \mathrm{m}$ (A-C"); $500 \mathrm{~nm}$ (D) $100 \mathrm{~nm}$ (D, nagyított felvétel). 
Ahhoz hogy megvizsgáljuk, hogy a tmod ${ }^{R N S i}$ fenotípus érzékeny-e a dDAAM fehérjeszint változásaira, a tmod csendesítést $d D A A M^{E x I}$ mutáns háttéren végeztük el. $\mathrm{A}$ miofibrillumok többsége $(\sim 80 \%)$ a vad típusra jellemző harántcsíkolt mintázatot mutatta jól kivehető M-vonalakkal és csak kis mértékben megváltozott alakú Z-korongokkal. A szarkomer hossz is a vad típushoz közelebb álló értéket mutatott $(2.8 \pm 0.13 \mu \mathrm{m} ; \mathrm{n}=30)$ (31. ábra C-C”). Ez a fenotípus arra enged következtetni, hogy az alacsonyabb dDAAM fehérjeszint szupresszálja mind az általános szarkomer szerveződési fenotípust, mind pedig a vékony filamentumok „túlnövekedési” fenotípusát, amelyet a $\operatorname{tmod}^{R N S i}$ muslicák indirekt repülőizmában láttunk. Mindez megerősíti, hogy a két fehérje ellentétes hatással van a vékony filamentumok elongációjára, a Tmod gátolja azt, míg a dDAAM elősegíti a növekedést.

Habár a dDAAM fehérje a szarkomerikus vékony filamentumok mínusz vége közelében is lokalizálódik, korábbi szerkezeti vizsgálatok azt jelzik, hogy a forminok kizárólag plusz vég kötő fehérjék (Xu és mtsai. 2004; Lu és mtsai. 2007; Shimada és mtsai. 2004). Ennek az ellentmondásnak az egyik magyarázata az lehet, ha a mínusz vég felöli elongáció rövid aktin fragmentumok képződésén alapul, amelyek fokozatosan, oligomerként épülnek be a plusz végükkel a Z-koronghoz rögzített növekvő filamentumokba. Ebben a feltételezett modellben (32. ábra) a dDAAM rövid aktin fragmentumokat hozna létre, klasszikus plusz vég kötő fehérjeként müködve, de emellett vagy aktív módon is elősegítené a fragmentumok beépülését, vagy legalábbis nem gátolná azt. 


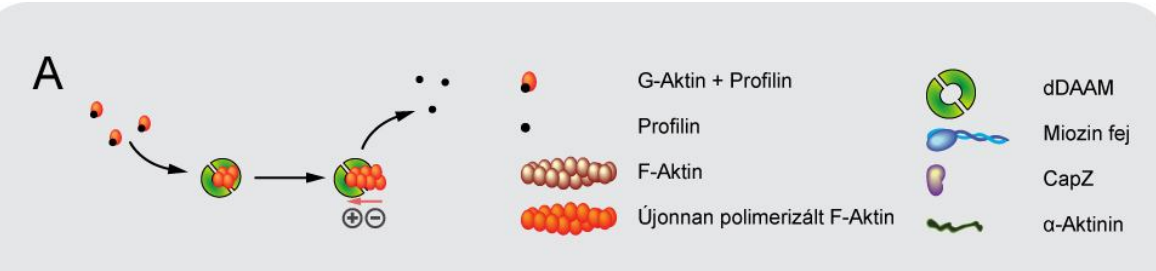

B
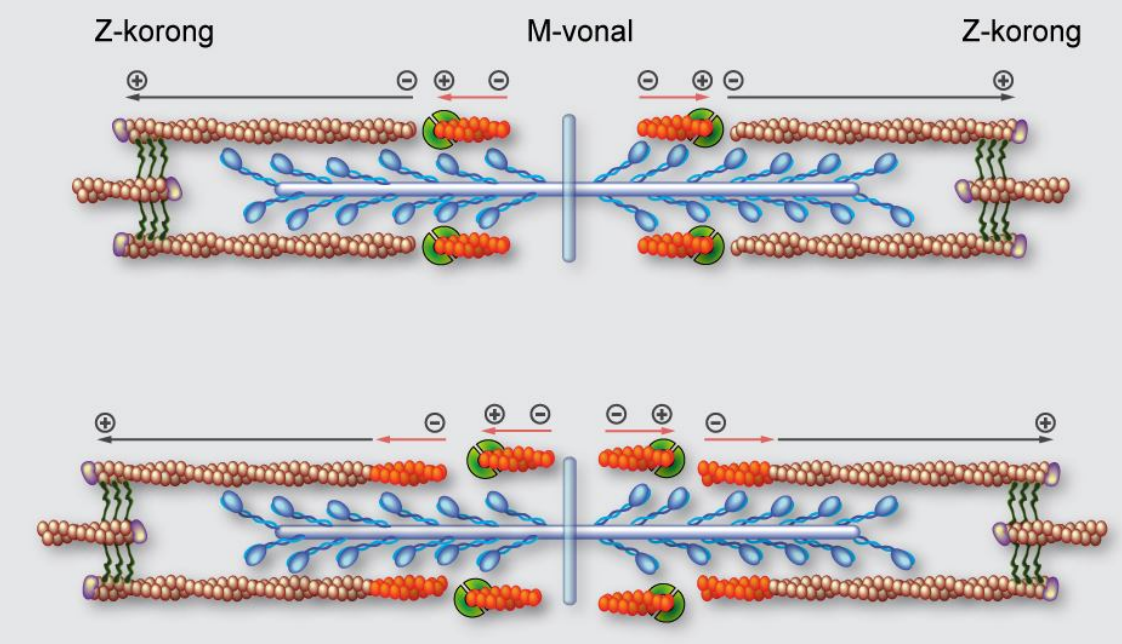

32. ábra A dDAAM által mediált mínusz vég felőli elongáció modellje. (A) A rövid aktin filamentumok nukleálása és elongálása a plusz vég kötő DAAM formin típusú fehérje által. (B) A vékony filamentumok mínusz vég felöli elongációjának egy lehetséges mechanizmusa a DAAM által összeszerelt rövid aktin filamentumok (narancssárgával jelölt) vég-vég kapcsolódása a Z-koronghoz kapcsolt hosszú, meglévő filamentumokhoz (barnával jelölt).

Hogy ezt a feltételezést igazolni tudjuk, egy in vitro F-aktin végillesztő aktivitási vizsgálatot végeztünk, melyben a dDAAM plusz vég kötő FH1-FH2 doménjeit használtuk. Azt találtuk, hogy az FH1-FH2 domén 100 nM-os koncentrációban nem gátolta az aktin filamentumok végeinek az összeolvadását (33. ábra D), habár korábbi in vitro vizsgálatokban, hasonló körülmények között a dDAAM FH1-FH2 doménjei szignifikánsan csökkentették a filamentumok plusz végeinek az összeszerelődését a pirén-jelölt aktin polimerizációs tesztben (Barko és mtsai. 2010). A korábbi vizsgálatokkal összhangban (Andrianantoandro és mtsai. 2001; Skau és mtsai. 2009), a plusz vég kötő CapZ fehérjének gátló hatása volt, a TM viszont elősegítette az aktin filamentumok vég-a-véghez illesztését, a TM és dDAAM együttes hatása pedig kissé még erősebb is volt, mint a TM-é egyedül (33. ábra D). Ebböl azt a következtetést vontuk le, hogy a dDAAM nem gátolta, sőt kismértékben segítette a TM végillesztő aktivitását, ami meglepő adat egy plusz vég kötő fehérjétől. Fenti modellünk alapján a mínusz véghez közeli 
dDAAM lokalizáció bizonyos értelemben félrevezető, valójában a dDAAM a mínusz vég közelében is plusz vég kötő fehérjeként viselkedik. Ebből következik, hogy a valódi mínusz vég kötő Tmod és a dDAAM között valószínüleg nem lehet direkt kölcsönhatás vagy kompetíció. Ezt a feltevésünket úgy próbáltuk ellenőrizni, hogy megnéztük milyen hatással van a dDAAM és Tmod fehérjék együttes túltermelése a szarkomer morfológiájára. Az IFM specifikus Tmod túltermelés a vékony filamentumok megrövidüléséhez vezetett (Mardahl-Dumesnil és mtsai. 2001) (33. ábra A'), míg a dDAAM fehérjeszint növelése nem okozott számottevő változást az IFM szintjén (33. ábra B-B").
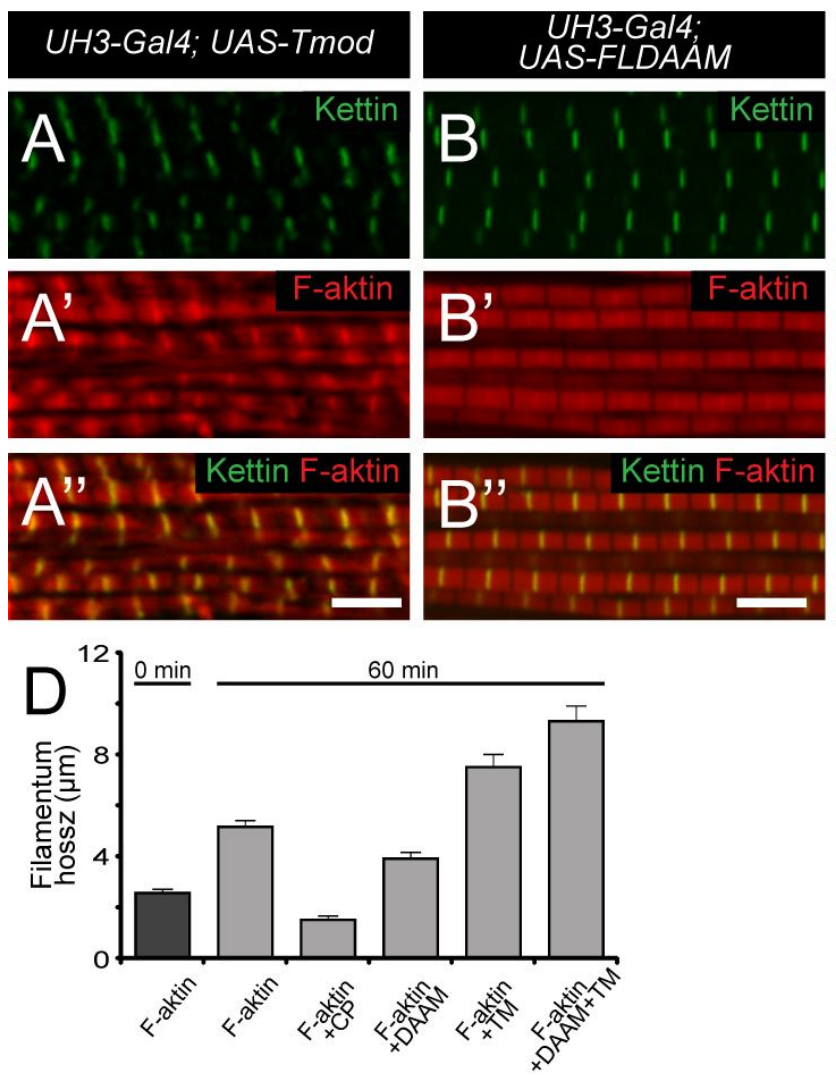
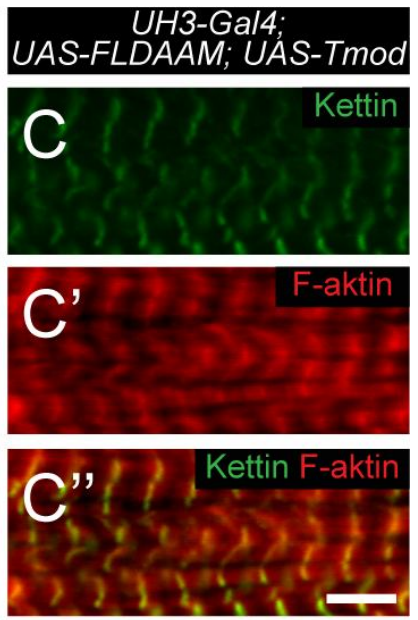

33. ábra A dDAAM plusz vég kötö fehérjeként viselkedik. (A-A") Az UH3-Gal4; UASTmod/+ genotípusú legyekben az F-aktin festés alapján a vékony filamentumok többsége rövidebbnek tünik a vad típusnál, míg az UH3-Gal4; UAS-FLDAAM legyek miofibrillumai nem különböznek a vad típustól (B-B"). Az FLDAAM és a Tmod fehérjék egyidejü túltermelése hasonló fenotípust eredményezett, mint a Tmod önmagában való túltermelése (CC" összehasonlítva AA"-val). Az A-C" paneleken a kettint zölddel, az aktint pirossal jelöltük. (D)

Aktin filamentum vég-vég kapcsolódás vizsgálata sötét szürkével a 0 perces kontrolt jelöltük, amely az átlagos filamentum hosszat ábrázolja $1 \mu \mathrm{M}$ F-aktin (F-aktin) jelenlétében, világos szürkével a 60 perces inkubáció utáni átlagos filamentum hosszakat ábrázoltuk az alábbiak szerint: $1 \mu \mathrm{M}$ F-aktin (F-aktin), $1 \mu \mathrm{M}$ F-aktin+ $10 \mathrm{nM}$ capping fehérje (F-actin+CP), $1 \mu \mathrm{M}$ F-aktin + 100 nM DAAM-FH1-FH2 (F-aktin+DAAM), $1 \mu \mathrm{M}$ F-aktin+ $1 \mu \mathrm{M}$ vázizom Tropomiozin (F-aktin+TM), valamint $1 \mu \mathrm{M}$ F-aktin+100 nM DAAM-FH1-FH2 + $1 \mu \mathrm{M}$ vázizom Tropomiozin (Factin+DAAM+TM) jelenlétében. Az oszlopok az átlagértéket ábrázolják, melyek fölött a szórások értéke található. A skála mérete: $5 \mu \mathrm{m}$. 
A két fehérje együttes túltermelése esetén a fenotipikus hatás megegyezett a Tmod önmagában való túltermelésének hatásával (33. ábra C-C”). Ez az eredmény jó összhangban van a feltételezésünkkel, hiszen jelzi, hogy a mínusz vég kötő Tmod fehérjével a dDAAM nem képes direkt módon versengeni, ami logikus, ha modellünknek megfelelően a dDAAM valójában a plusz végekhez kötődik.

A fenti kísérleti adatok megerösítik elképzeléseinket a feltételezett végillesztési mechanizmusról, amelyben a dDAAM fehérje által létrehozott oligomer aktin filamentumok összekapcsolódnak a növekvő filamentumok végeivel.

\subsection{Evolúciós konzerváltság}

Mivel sok izom fehérje esetében magas evolúciós konzerváltságot mutattak ki, és az egér Daam1 (mDaam1) génről kimutatták, hogy részt vesz a szívfejlődésben (Li és mtsai. 2011), ezért úgy döntöttünk, hogy immunfestéses kísérletben megvizsgáljuk az mDaam1 fehérje lokalizációját 15 napos egerekből származó harántcsíkolt izommetszeten. A vizsgált izmok közül az $m$. tibialis anterior metszeten az mDaaml fehérje két sávban, az M-vonal két oldalán lokalizálódott, míg az $m$. vastus lateralis metszeten a legtöbb fehérjét a Z-korongok környékén mutattuk ki (34. ábra A-B”). A következőkben kíváncsiak voltunk arra is, hogyan alakul az mDaam1 lokalizációs mintázata a miofibrillogenezis korai időszakában. Ehhez egy C2C12 nevü egér miogén sejtvonalat (Yaffe és Saxel 1977) és markerként $\alpha$-aktinint használtunk. Az $\alpha$ aktinin a miofibrillogenezis egyik korai markerének számít (Kontrogianni-Konstantopoulos és mtsai. 2006). Azokban a $\mathrm{C} 2 \mathrm{C} 12$ sejtekben, amelyeket 24 órával az izom irányba történő differenciálódásuk után vizsgáltunk, az mDaam1 fehérjét a szarkomerek szintjén két széles sávban detektáltuk a Z-korong kezdemények (Z-testek) és az M-vonalak között (34. ábra E-E”). A 48 és 96 órás differenciálódott $\mathrm{C} 2 \mathrm{C} 12$ sejtekben a 24 óráshoz hasonló festődési mintázatot 
láttunk (34. ábra F-F”). A két, mDaam1 által jelölt szarkomerikus sáv helyének pontosabb meghatározására kettős festés használtunk, az $\alpha$-Titin (9D10) és az $\alpha$-myomesin (B4) ellenanyagok segítségével 96 órás differenciálódott sejteken. A 9D10 ellenanyag a PEVK régiót jelöli a Titin óriásmolekulán, amely az I-sávban lokalizálódik, közel az I- és A-sáv közötti határhoz (Trombitas és mtsai. 1998; Wang és mtsai. 1988), míg a B4 ellenanyag az M-vonalat jelöli (Grove és mtsai. 1984).
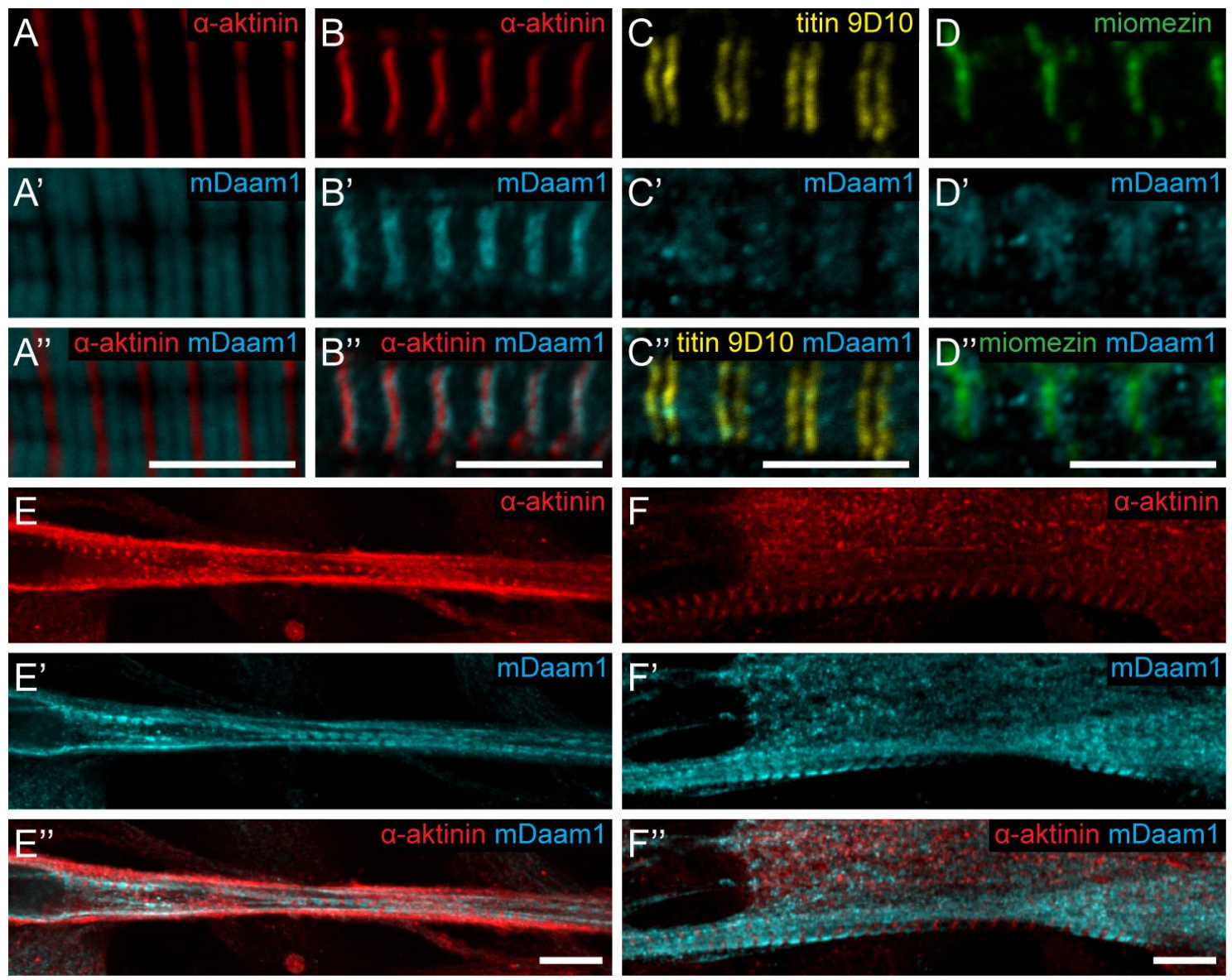

34. ábra Az mDaam1 fehérje szarkomerikus lokalizációja. (A-B”) Egér izom metszetek mDaam1 (ciánkékkel jelölve) immunfestése (a Z-korong marker $\alpha$-aktinin pirossal jelölt). A m.tibialis anterior szarkomereiben az mDaam1 fehérje az M-vonal két oldalán (A-A"), míg a $m$ vastus lateralis-ban többnyire a Z-korongok környékén lokalizálódik (B-B"). A 96 óráig differenciáltatott C2C12 sejtekben az mDaam1 immunfestés (ciánkékkel jelölve) a szarkomer közepén két széles sávot ad, melyek nem fednek át a Titin festődéssel (sárgával jelölt; 9D10 ellenanyag) (C-C") sem az M-markernek tekintett miomezin sávokkal (zölddel jelölve) (D-D"). (E-F") Az mDaam1 (ciánkékkel jelölt) és az $\alpha$-aktinin (pirossal jelölt), festődési mintázata a 24 (E-E”) és 96 óráig (F-F”) differenciáltatott $\mathrm{C} 2 \mathrm{C} 12$ sejtekben. A skála mérete: $5 \mu \mathrm{m}$ (A-D”); $15 \mu \mathrm{m}$ (E-F”). 
Azt találtuk, hogy az mDaam1 festődés szignifikáns mértékben nem fed át egyik sávval sem, amit az elöbb említett ellenanyagok jelölnek (34. ábra C-D”), jelezve, hogy az mDaam1 fehérje nagy része az M-vonal és az I-A határvonala között halmozódik fel, abban a régióban ahol a vékony és vastag filamentumok átfednek egymással.

Ezek alapján az mDaam1 fehérje szarkomerikus lokalizációjával kapcsolatban két fontos következtetést vonhatunk le. Egyrészt, az izom specifikus különbségeket leszámítva, az mDaam1 szubszarkomerikus lokalizációja alapvetően megegyezik a Drosophila DAAM fehérjéével a Zkorong és M-vonal környéki lokalizáció vonatkozásában. Másodsorban, az mDaam1 a szarkomer kezdeményekben ugyanolyan korán jelenik meg, mint az aktin keresztkötő $\alpha$-aktinin, ami összhangban van azzal az elképzelésünkkel, hogy ennek a forminnak korai szerepe van a miofibrillogenezis során.

\subsection{A dDAAM és a miozin közötti kölcsönhatás}

Azon kívül, hogy a dDAAM fehérjének meghatározó hatása van a vékony filamentumok növekedésre, az EM analízis egy további, részben meglepő eredménnyel is szolgált, miszerint a dDAAM hiány a vastag filamentumok alakját és szerveződését is befolyásolja. Ezek az eredmények arra engednek következtetni, hogy a $d D A A M$-ra az aktin szabályozó szerepén kívül szükség lehet a vastag filamentumok szerkezetének a kialakításában és/vagy az aktin és miozin filamentum rendszerek összehangolt felépítésében a rendezett szarkomer struktúrán belül. Hogy a dDAAM és a miozin közötti lehetséges kölcsönhatást ki tudjuk mutatni, ismét a $d D A A M^{E x I}$-es hipomorf mutáns hátteret használtuk genetikai interakciós vizsgálatokhoz. Izomspecifikus miozin nehéz lánc $m h c$ mutánssal, és a zipper (zip) nem-izom miozin izoformát kódoló alléllal is megvizsgáltuk a kölcsönhatást. Azt találtuk, hogy az $m h c^{1}$ vagy zip ${ }^{2}$ heterozigóta formában nem befolyásolta szignifikánsan az életképességet, viszont a $d D A A M^{E x I} ; m h c^{1} /+$ és a $d D A A M^{E x I}$; 
zip $/+$ mutáns hímek életképessége erősen lecsökkent $(2.7 \%$ illetve $8.1 \%$-os a túlélő hímek aránya az ugyanabból a keresztezésből származó nőstény állatok számához viszonyítva). A $d D A A M^{E x I} ; z i p^{2} /+$ felnőtt túlélő állatok röpképessége nem változott, és ennek megfelelően az indirekt repülőizmuk szerkezete is a vad típuséhoz volt hasonló. Ezzel ellentétben a $d D A A M^{E x I}$; $m h c^{1} /+$ állatok röpképtelenek, ahogy az $m h c^{1} /+$ heterozigóta mutánsok is azok. Az $m h c^{1} /+$ heterozigóták indirekt repülőizmában szerkezeti hibákat mutattunk ki, mint például a miofibrillum átmérőjének és a szarkomer hossznak a csökkenését (a szarkomer hossz csökkenés elérte a $\sim 22 \%$-ot), részben rendezetlen struktúrájú Z-korongokat, és szétváló izomrostok jelenlétét (35.ábra A-A') (Beall és mtsai. 1989; O'Donnell és Bernstein, 1988). A fent említett fenotípusos elváltozások súlyosbodtak amennyiben az $m h c^{l}$ allél $d D A A M^{E x I}$-es háttérre került. Különösen a Z-korong szerveződés volt rosszabb, mint az $m h c^{1} /+$ heterozigótában, a szarkomer hossz csökkenés pedig gyakran elérte a $37 \%$-ot, és a miofibrillumok általános szerveződése is sokkal lazább volt mint az $m h c^{1} /+$ heterozigótáknál általában (35.ábra B-B').

Érdekes módon, az Act $88 F^{k m 88}$ mutáció, a $d D A A M$-mal ellentétben, dominánsan szupresszálja az $m h c^{1} /+$ izom fenotípust (Beall és mtsai. 1989). Ha a $d D A A M$ összes izommal kapcsolatos funkciója kizárólag csak az aktin szabályozáshoz kötődne, nem lenne várható egy ilyen, az aktin mutánssal ellentétes hatás az $m h c$ interakció vonatkozásában. Ezért az életképességet és az izomszerkezetet érintő, az $m h c$ és a $d D A A M$ közötti domináns genetikai kölcsönhatás arra utal, hogy a dDAAM az MHC fehérjével összehangoltan müködik az izomfejlődés során, és úgy tünik, hogy ez a kölcsönhatás a $d D A A M$ aktin szabályozó funkciójától független. Ráadásul, említésre méltó, hogy a $d D A A M^{E x I} ; z i p^{2} /+$ kettős mutánsok csökkent életképessége is a legjobban azzal magyarázható, hogy a miozin/dDAAM kölcsönhatás a nemizom sejtekben is fontos szerepet játszik. A dDAAM/MHC kölcsönhatást tovább elemezve 
megvizsgáltuk a dDAAM fehérje lokalizációját az Act88F mutánsok IFM-jében. Az Act $88 F^{k m 88}$ homozigóta mutánsok IFM-jéből teljesen hiányoznak a vékony filamentumok (Beall mtsai. 1989), ennek ellenére nem találtunk csökkenést a dDAAM fehérje szintben az $A c t 88 F^{k m 88} / A c t 88 F^{k m 88}$ mutáns indirekt repülőizmokban (35. ábra E).
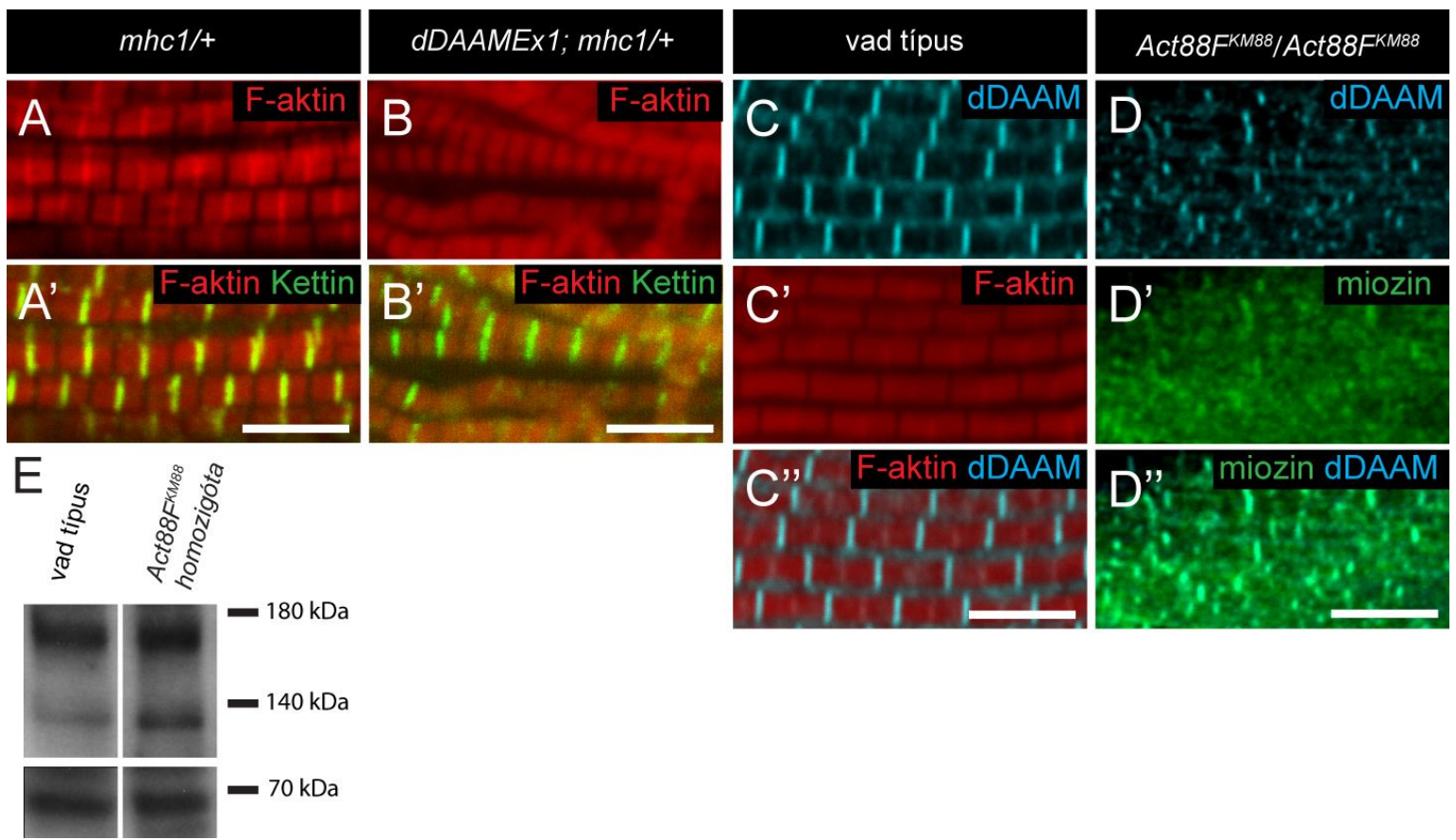

35. ábra A dDAAM és a miozin közötti kölcsönhatás. (A-A') Az $m h c^{1} /+$ legyek IFM-jeiben a szarkomer hossz csökkenés elérte a $\sim 22 \%$-ot, és a Z-korongok struktúrája is részben érintett. Ezek a fenotípusos elváltozások súlyosbodtak a $d D A A M^{E x l} ; m h c^{1} /+$ legyekben (B-B'). A szarkomer hossz csökkenés itt elérte a 37\%-ot. A Z-korong szerveződés gyengébb, a miofibrillumok általános szerveződése pedig sokkal lazább volt. A vad típusú IFM-ben a dDAAM a már említett módon, a Z-korongok, az M-vonalak környékén és a szarkoplazmában egyaránt lokalizálódik (C-C”). Az Act $88 F$ null homozigóta mutánsok IFM-jében, melyekből teljesen hiányoznak a szarkomerikus vékony filamentumok, a dDAAM fehérje viszont az izomrostokkal asszociált formában marad, és egy részleges kolokalizációt mutat a miozinnal (D-D”). (E) A Western blot analízis segítségével nem találtunk különbséget a vad típusú és az $A c t 88 F$ null homozigóta mutáns IFM-ek dDAAM fehérje szintje között. A skála mérete: $5 \mu \mathrm{m}$.

Ezen túlmenően, a dDAAM fehérje asszociált maradt a kialakuló izomrostokkal, amelyek az Act88F hiányában képződtek, és ahelyett hogy a festődése egyenletes vagy teljesen véletlenszerü lenne, a fehérje pontozott illetve sávozott eloszlást mutatott az izomrostokban. Ez jelezte, hogy ezeknek a rostoknak a szerveződése nem szünt meg teljesen, és ezek mentén még mindig léteznek dDAAM kötőhelyek (35. ábra D). 
Tekintve, hogy az Act $88 F^{k m 88}$ mutánsok izomrostjai olyan vastag filamentumokból állnak, amelyek legalább részben megtartották az egyenletes illeszkedésüket (Beall és mtsai. 1989), ezek az eredmények azt mutatják, hogy a dDAAM fehérje képes kötődni a vastag filamentumokhoz, ez pedig további közvetett bizonyítékként szolgál a dDAAM és a miozin között fennálló kölcsönhatás igazolására. 


\section{AZ EREDMÉNYEK MEGVITATÁSA}

A szarkomerikus aktin filamentumok az izmok alapvető szerkezeti és müködési egységeit képezik, de a filamentumok kialakulása és a szabályozási mechanizmus, amely a miofibrillogenezis során zajlik, még nem ismert. A vékony (aktin) filamentumok kialakulásának kezdeti lépéseihez nukleációs faktorok szükségesek, ezek közül eddig a Leiomodin és a Fhod3 fehérjéket írták le, mint izom specifikus nukleációs faktorokat, és hozták kapcsolatba a szarkomerikus aktin filamentumok elongációjával (Chereau és mtsai 2008; Taniguchi és mtsai 2009). A későbbi funkcionális analízisek során viszont kimutatták, hogy ezeknek a fehérjéknek nem a kezdeti aktin nukleációs lépésekben, hanem inkább a későbbi, a miofibrillumok fenntartását célzó aktin polimerizációban van szerepük. A C. elegans-ban végzett újabb kutatási eredmények arról számolnak be, hogy a formin fehérje család másik két tagja, a Cyk-1 (Diaphanous ortológ) és a Fhod-1, a Z-korongok környékén lokalizálódnak, és a rendezett filamentum struktúra növekedésében és fenntartásában játszanak szerepet (Mi-Mi és mtsai. 2012). Meglepö módon, a cyk-1 és a fhod-1 mutánsok fenotípusa viszonylag gyenge, és még nem tisztázott, hogy egyéb nukleációs faktorokra szükség van-e a fonálféreg izmok fejlődéséhez.

Munkánk során in vivo bizonyítékkal szolgáltunk arra nézve, hogy a DAAM - úgyszintén a formin fehérje család tagja - fontos szerepet játszik a szarkomerikus aktin filamentumok kialakulásában. Sikerült bizonyítanunk, hogy a DAAM fehérje szükséges a vékony filamentumok elongációjához, és hogy a DAAM aktin összeszerelő aktivitása nélkülözhetetlen a müködőképes izmok kifejlődéséhez. Emellett azt is sikerült kimutatni, hogy a differenciálódó C2C12-es sejtekben az egér Daam1 ortológ ugyanolyan korán megjelenik a szarkomer kezdeményekben, mint a korai markernek tartott $\alpha$-aktinin. Ezért a DAAM formin fehérje alcsalád tagjai nagy valószínűséggel részt vesznek a miofibrilláris aktin filamentumok korai 
összeszerelődésében is. Érdekes módon, annak ellenére, hogy a Drosophila DAAM mutánsok izmai csökkent F-aktin tartalommal rendelkeznek, bizonyos mennyiségü vékony filamentum jelen van ezekben a mutáns izmokban. Hozzá kell tennünk viszont, hogy az izomszerkezet vizsgálatához rendelkezésünkre álló mutánsok közül egyik sem fehérje null allél. Ez megakadályoz bennünket abban, hogy kiderítsük, hogy vajon egy másik aktin nukleációs faktor, mint például a Dia vagy a Fhos, szükséges ahhoz, hogy ez az alacsony mennyiségü F-aktin szint jelen legyen, vagy a dDAAM fehérje csökkent szintje önmagában is elégséges a képződéshez.

Eredményeink azt bizonyítják, hogy a $d D A A M$ a szarkomer fejlődés szempontjából fontos aktin összeszerelö faktor. Fontos adat, hogy a gerinces DAAM ortológok nagy mennyiségben találhatók a fejlődő szomitákban és a szívben (Li és mtsai. 2011; Nakaya és mtsai. 2004), és az mDaaml genetikai analízise során kimutatták, hogy a fehérje szerepet játszik a kardiomiociták szarkomer szerveződésében (Li és mtsai. 2011). A mi eredményeinkkel együtt ez azt jelentené, hogy a szarkomerikus aktin filamentumok kialakítása egy evolúciósan konzervált DAAM funkció.

Kísérleteink során azt találtuk, hogy a többi vékony filamentum összeszerelő fehérjékre jellemző módon, az IFM-ben a dDAAM fehérje a vékony filamentumok mindkét oldalán lokalizálódik. Korábban már kimutattuk, hogy in vitro körülmények között a dDAAM bona fide forminként viselkedik, vagyis rendelkezik mindazon tulajdonságokkal, amelyeket más forminokról leírtak (Barkó és mtsai. 2010). Elképzeléseink szerint a Z-korong környéki dDAAM a G-aktin beépülést szabályozza az aktin filamentumokba a plusz vég felöl. A forminokra jellemző, hogy képesek elősegíteni új aktinláncok kialakulását, a gyorsan növekvő véghez való kötődésük egyben védő és szabályozó funkciót is jelent (processive capping). Mivel az IFM-ben a szarkomerikus dDAAM expresszió, a Z-korong környéki feldúsulást is beleértve, felnőttkorban 
is fennmarad, valószínűnek tartjuk, hogy a dDAAM fehérje hozzájárul a normális miofibrilláris struktúra és működés fenntartásához.

A Z-korong környéki lokalizáción kívül a dDAAM a vékony filamentumok mínusz végeinek közelében is felhalmozódik. Tekintve, hogy a dDAAM elösegíti a vékony filamentumok növekedését és ellentétesen müködik az F-aktin mínusz végének sapkázó fehérjéjével, a Tropomodulinnal, erre a legegyszerübb magyarázat az lenne, hogy a dDAAM részt vesz a filamentumok mínusz vég felőli elongációjában. Ez összhangban lenne azzal a bizonyítékkal, hogy a szív miocitákban és a Drosophila primer sejtkultúrákban az aktin dinamika a filamentumok mínusz végein van túlsúlyban (Littlefield és mtsai. 2001; Bai és mtsai. 2007). Viszont a mínusz véghez közeli lokalizáció váratlan egy plusz vég kötő formin típusú fehérjétől. A rendelkezésünkre álló strukturális analízisek kizárják annak a lehetőségét, hogy egy formin típusú fehérje közvetlen módon kötődhessen a mínusz véghez. Elméletileg elképzelhető, hogy a dDAAM mínusz vég lokalizációja egy - a dDAAM-mal kölcsönhatásban levő - ismeretlen fehérjének tudható be. Egy másik lehetséges magyarázat lehet az, hogy a vékony filamentumok mínusz végei közelében is előfordulnak F-aktin plusz végek, amelyekhez a dDAAM kötódik. Habár teljességgel nem tudjuk kizárni az első lehetőséget sem, jelenleg annak a fajta fehérjefehérje kölcsönhatásnak a mibenléte és a funkcionális jelentősége nem tisztázott. Ezért valószínűbbnek tartjuk a második elképzelést, amely az aktin összeszerelődéssel kapcsolatos érdekes kérdéseket is felvet. Ha plusz végek valóban léteznek a mínusz végek közelében, akkor a mínusz vég felőli elongáció azáltal tud megvalósulni, hogy a rövid aktin filamentumok vég-vég kapcsolódással hozzáadódnak a már meglévő hosszabb, és Z-korongokhoz rögzített filamentumokhoz (32. ábra). Egy ilyen növekedési mechanizmus, ha in vivo körülmények között bizonyítható lenne, magyarázatot adna a fent említett mínusz vég felőli gyors elongációra. 
A kísérleti eredményeink összeegyeztethetőek ezzel a modellel, amelyben a dDAAM mint plusz vég kötő fehérje elősegíti a kis fragmentumok kialakulását, és egyben lehetővé teszi az aktin vég-vég kapcsolódást is. Fontos kérdés, hogy mekkora lehet ezeknek a kis aktin fragmentumoknak a mérete. Ezzel kapcsolatban érdekes megfigyelés, hogy hasadó élesztőben (Schizosaccharomyces pombe) a kontraktilis gyürü kialakulása során a Cdc12p nevü formin típusú fehérje rövid aktin filamentumokat nukleált, amelyek aztán Tropomiozin (TM) jelenlétében kapcsolódtak egymáshoz. Ezzel összhangban, a mi in vitro kísérleteinkben a TM kétszeresére növelte az aktin filamentumok vég-vég kapcsolódását. A TM fontos összetevője a vékony filamentumoknak, és kísérleti adataink vannak arra nézve, hogy az IFM specifikus Tm2 mutáció dominánsan erösítette a $d D A A M^{E x l}$ vékony filamentum fenotípusát. Ezért a kis filamentumok mérete véleményünk szerint nem lenne nagyobb 37-38 nm-nél, ami egy Tropomiozin molekula hosszának felel meg, mert ez stabilizálná a kis fragmentumot. Mivel az aktin filamentumok vég-vég kapcsolódása spontánul is végbemegy, a szarkomeren belüli folyamat jobb megértéséhez további kísérletek szükségesek, melyek közül a legfontosabb a szóban forgó rövid aktin filamentumok vizualizálása. Mindamellett megjegyzendő, hogy az említett Fhod3 formin típusú fehérje, amely a miofibrillumok fenntartásában és érésében játszik szerepet (Iskratsch és mtsai. 2010; Kan-O és mtsai. 2012), szintén lokalizálódik a mínusz végek közelében (Taniguchi és mtsai. 2009; Kan-O és mtsai. 2012), és ezért elképzelhető, hogy az aktin filamentumok összeszerelődését a dDAAM-hoz hasonló módon szabályozza.

A vékony filamentum növekedéssel foglalkozó korábbi modellek azt az elképzelést támogatták, hogy a növekedés egy kétlépéses mechanizmus során valósulhat meg (Bai és mtsai. 2007; Mardahl-Dumesnil és Fowler 2001). Ennek megfelelően az első lépésben rövid filamentumok képződnek, majd ezek a filamentumok csak a második lépésben érik el a végleges 
hosszúságukat. Ezenfelül azt feltételezik, hogy - legalábbis a lárvális izmokban - az első lépés a SALS fehérje közremüködése nélkül történik, míg a rákövetkezö lépésben a mínusz vég felöli elongációhoz már szükség van a SALS müködésére, amely a Tropomodulin capping aktivitását szünteti meg (Bai és mtsai. 2007). A $d D A A M$ mutánsban megfigyelt szarkomer rövidülés amellett szól, hogy a dDAAM fehérjére az említett vékony filamentum növekedési modell második lépésében lenne szükség. Másrészt, a súlyos Z-korong szerveződési defektusok és a csökkent szarkomer szám a lárvális izmokban mind arra utal, hogy a dDAAM-nak egy korai szerepe is lehet, és ez a szerep kapcsolódik a vékony filamentumok kialakulásának kezdeti lépéséhez. A C2C12 sejtdifferenciációs kísérletben az mDaam1 fehérje lokalizációs adatai is összhangban vannak a korai funkciót illető feltételezéssel. Ezért a dDAAM egy jó jelöltnek tünik ahhoz, hogy részt vehessen a szarkomerikus vékony filamentumok kialakulásának első lépéseiben. Az viszont továbbra is nyitott kérdés marad, hogy az aktin filamentumok vég-vég kapcsolódása az aktin filamentumok nukleációjának/elongációjának kezdeti, -második vagy mindkét lépésében megtörténhetne.

Érdekes módon, a vékony filamentumok kialakulására gyakorolt erős hatáson kívül, a dDAAM a vastag filamentumok és a rendezett miofibrilláris struktúra szerveződését is befolyásolja. Habár ezek a fenotípusok a vékony filamentum rendszer súlyos károsodásának indirekt következményeként is felléphetnek, egy másik lehetséges magyarázat az lehet, hogy a dDAAM-nak jóval komplexebb szerepe van a szarkomerogenezisben. Emellett szól például az a megfigyelés, hogy a $d D A A M$ mutánsokban a filamentum rendszerek szerveződése sokkal jobban károsodott, mint az Act $88 F$ null mutánsok esetén, pedig az utóbbiakból teljesen hiányoznak a vékony filamentumok (Beall és mtsai. 1989). Ráadásul, ezeknek a vékony filamentumoknak a hiánya ellenére, az Act88F mutánsok indirekt repülőizmában azt találtuk, hogy a dDAAM 
fehérje továbbra is kötődött a miofibrillumokhoz, egy eléggé specifikus festődési mintázatot mutatva, amely nagyrészt az izom típusú miozin immunfestéssel kolokalizált (35. ábra D”). A mutáns izmokat Western blot analízissel tovább vizsgálva azt találtuk, hogy a dDAAM fehérje mennyisége nem változott a vad típushoz képest (35. ábra E). Figyelemre méltó az is, hogy az aktin izoformák túltermelésével ellentétben (Röper és mtsai. 2005), a dDAAM fehérje túltermelése a lárvális izmokban szignifikánsan megnövelte a szarkomerek számát és az izom méretét, miközben a szarkomer hossz a vad típushoz közeli értéket mutatott. A fenti megfigyelések alapján feltételezzük, hogy a vékony filamentum nukleáló/elongáló szerepe mellett, a dDAAM a szarkomerogenezis során az aktin és miozin filamentumrendszerek koordinálásában is lényeges szerepet játszik. Mindent összevetve egyértelmü, hogy a dDAAMnak meghatározó szerepe van a szarkomer összeszerelödésben, és tudomásunk szerint ez az egyetlen ismert fehérje, amelynek izomspecifikus túltermelése ilyen látványos hatást gyakorol az izomfejlődésre. 


\section{ANYAGOK ÉS MÓDSZEREK}

\subsection{Felhasznált Drosophila törzsek}

$w^{1118}$ mint vad típusú kontroll

$d D A A M^{E x I}$

$d D A A M^{E x 68} / F M 7 c, K r-G F P$

$w ; U A S-F L D A A M$ vagy $U A S-D A A M-P B$

$y w ; D M e f 2-G a l 4$

w; UH3-Gal4

$w ; U A S-D c r 2$

$r y^{506} \operatorname{tmod}^{00848} / \mathrm{TM} 3$

w; UAS Tmod

$r y^{506} \operatorname{Act}^{8} 8 F^{K M 88} e$

$y w ; \operatorname{Tm} 2^{3}$

$r y^{506} \mathrm{Tm} 1^{02299} / \mathrm{TM} 3$

w; sals ${ }^{f 07849} / T M 6 B$

w Act5 ${ }^{C G 0025} / F M 7 c$

$w ; s l s-G F P$

w; UAS-Tmod ${ }^{R N A i}$ (NIG-FLY, Kyoto)

w; UASdDAAM ${ }^{K K 102786}$ (VDRC, Bécs)

Az $U A S-d D A A M^{R N A i-T 129 M} d D A A M$ specifikus RNS interferenciás vonal, amely az RE67944 dDAAM cDNS klónon a 2562 - 3068 nukleotid közötti szakaszt célozza meg, a standard klónozási és transzformációs módszerekkel készült. Az UAS-DAAM-PD klón készítéséhez a PD izoforma specifikus régiót amplifikáltunk fel olyan cDNS állományból, amely 
reverz transzkripcióval az L3-as stádiumú lárva mRNS készletből lett generálva. Először egy pENTR3C-DAAM-PD klónt hoztunk létre, amelyet később arra használtunk, hogy a transzgenezisre megfelelő cél vektorokat, pTW-DAAM-PD (UAS-DAAM-PD) állítsunk elő. Az $U A S-D A A M-P B^{I 732 A}$ és az $U A S-D A A M-P D^{I 1042 A}$ mutánsokat a standard klónozási módszerekkel hoztuk létre, templátként használva a pENTR3C-DAAM-PB és a pENTR3C-DAAM-PD klónokat az in vitro mutagenezises kísérletekhez.

Az in situ C-terminálisan GFP-jelölt $d D A A M^{E G F P}$ (knock-in) allélt egy kétlépéses P-elem mediálta génkonverziós kísérlettel hoztuk létre. Első lépésben egy úgynevezett targetáló kontrukció lett összeszerelve. Ehhez egy módosított pBS vektort használtunk, amelybe

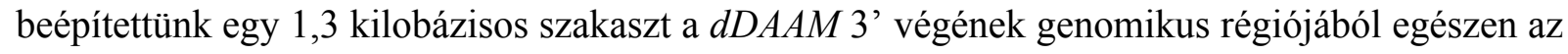
utolsó kodonig. Ezt követte egy 2,3 kilobázisos Gal4::VP16 fragment, mindkét oldalán I-SceI hasító helyekkel határolva. Ezután egy 1150 bázispár hosszú fúziós fragmentet építettünk be,

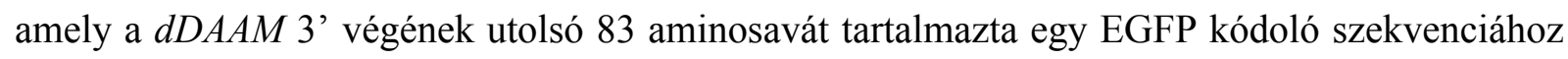
fuzionáltatva, és stop kodonnal ellátva. Végül az egész 3' nem transzlálódó (UTR) régió és az ezt követő downstream 1,1 kilobázisos genomi régió is beépítésre került. Ily módon, a körülhatároló genomi szekvenciákon kívül, a kontrukció hordozta a Gal4::VP16 marker gént, amelyet I-SceI hasítóhelyek és egy megközelítőleg 250 bázispár hosszú genomi duplikáció határolt. A duplikáció a $d D A A M$ gén C-terminális végének legutolsó kódoló szekvenciáit tartalmazta.

Ez a targetáló konstrukció lett a $d D A A M$ genomi régiójába konvertálva, miután az EP (1) 1542 nevű P-elemet remobilizáltuk. (A P-elem inszerció a dDAAM-tól 200 bázispár távolságra downstream helyezkedik el). A remobilizálás céljából az EP (1) 1542 szüzeket $r y^{502} F a b-7^{1} \Delta 2-3$ (dr. Sipos László, MTA SZBK, ajándéka) hímekhez kereszteztük és az embrionális utódokat a targetáló konstrukcióval injektáltuk. Ezeket az utódokat aztán nagyszámú w; UAS-EGFP 
legyekhez kereszteztük és a keresztezéseket szén és agar tartalmú táptalajon petéztettük. Az embriókat legyüjtöttük, és a frissen kikelő lárvákon MZ FLIII sztereó mikroszkóp (Leica, Svájc) segítségével GFP fluoreszcencia szürést (screen) végeztünk. Azokat a lárvákat, amelyek tracheájában és idegrendszerében magas GFP expressziót tapasztaltunk, törzsalapításra használtuk fel. A génkonverziós esemény megvalósulását PCR-rel és szekvenálással igazoltuk. Ahogy a Gal4::VP16-ot tartalmazó konstrukció a konverzió folyamán sikeresen beépült a dDAAM génbe, a következő keresztezés során I-SceI segítségével kettős szálú DNS törést indukáltunk. Ennek a kettősszálú törésnek a javítása pedig nagy valószínüséggel a $\sim 250$ bázispárt tartalmazó duplikált $d D A A M$ régiók közötti homológ rekombinációval történhetett meg. Ez az esemény, melyet PCR-rel és szekvenálással igazoltunk, az EGFP szakasz kivételével az összes nem Drosophila szekvencia eltávolításához vezetett, minek eredményeképpen egy Cterminálisan jelölt $d D A A M$ allélt kaptunk. A $d D A A M^{\text {EGFP }}$ allél életképes és fertilis homo-, illetve hemizigóta formában is, ami azt jelzi, hogy az EGFP jelenléte nem befolyásolja szignifikánsan a dDAAM fehérje funkcióját.

\subsection{Immunhisztokémia}

A frissen kikelt adultok IFM-jének boncolását foszfát pufferben (PBS) hígított 4\%-os paraformaldehidben (PF) végeztük, majd fixálás céljából 15 percig inkubáltuk az oldatban. Ezután a fixált mintákat relaxáló oldatban $\left(6 \mathrm{mM} \mathrm{MgCl}_{2}, 5 \mathrm{mM}\right.$ EGTA, $5 \mathrm{mM}$ ATP, $90 \mathrm{mM}$ kálium-propionát, $20 \mathrm{mM} \mathrm{NaPi}$, pH 7.0) mostuk háromszor 30 percig. A mosás után az izmokat éjszakán át (kb. $18 \mathrm{~h}) 4^{\circ} \mathrm{C}$-on Triton-X/glicerin oldatban (50\% v/v glicerin, 0.5\%Triton X-100, 20 $\mathrm{mM} \mathrm{NaPi}, 2 \mathrm{mM} \mathrm{MgCl} 2,1 \mathrm{mM}$ EGTA, $5 \mathrm{mM}$ DTT, pH 7.0) permeabilizáltuk majd újabb mosás után relaxáló oldatban hígított elsődleges és másodlagos ellenanyagokkal festettük. A „frissen kikelt" adult legyek kategóriájába a kikelés után számított 0 és 8 óra közötti muslicák tartoztak. 
A báb IFM boncolás esetén, miután az időzített állatokat eltávolítottuk a bábtokból, a fejüknél fogva rovartűvel a hátoldalukra fektetve Sylgard (Dow Corning) lemezre rögzítettük, majd PBSben hígított 4\%-os PF fixálót mértünk rájuk. Miután a hasi középvonal mentén felvágtuk, a gyengébben kötődő zsírtesteket egy fecskendő segítségével öblítéssel eltávolítottuk, hogy az IFM-hez hozzájussunk. Ezeket leválasztottuk, fixálóban inkubáltuk (PBS-ben hígított 4\%-os PF) 15 percig, majd relaxáló oldatban mostuk. A báb fejlődési stádiumok pontos időzítéséhez az úgynevezett fehér „előbábokat” (prepupa) friss fiolákba helyeztünk, majd ezeket $25^{\circ} \mathrm{C}$-on tárolva a kívánt időpontokban gyüjtöttünk le.

A lárvális szívcső boncolásnál relaxáló oldatban metszettük fel a lárvák testfalát, majd ezeket PBS-ben hígított 4\%-os PF-ben fixáltuk (az Alayari és mtsai. 2009-ben leírtak szerint). Miután a zsírtesteket és a belső szerveket eltávolítottuk, előzetes mosás után a szívcső preparátumokat PBS-BT-vel (PBS, 0,1\% Triton-X, 0,2\% BSA) minimum 1 órát blokkoltuk. E lépés során a BSA telíti a fehérjekötő helyeket, így az immunhisztokémiai eljárás alatt az antitest specifikusabban kötődik. A blokkolt mintákat éjszakán át (kb. 18h) festettük $4^{\circ} \mathrm{C}$-on PBS-BTben megfelelő koncentrációra kihígított elsődleges ellenanyaggal, majd 0,1\% Triton X-100-t tartalmazó PBS-ben (PBS-T) mostuk háromszor 30 percig. Ezután szobahőmérsékleten a fluoreszcens másodlagos ellenanyagot tartalmazó PBS-BT-ben 3 órát inkubáltuk (a fluoreszcens festésnél az inkubáció sötétben zajlik). Ezt háromszor 30 percig tartó mosás követte. Utolsó lépésként a mintákat gicerin:PBS 4:1 arányú keverékében helyeztük tárgylemezre, és fedőlemezzel lefedve Olympus FV1000 LSM konfokális mikroszkóppal vizsgáltuk. A konfokális mikroszkópiás képeket az ImageJ (NIH) és az Olympus FW10-ASW (1.7a. verzió) szoftverek segítségével szerkesztettük. 


\subsubsection{Felhasznált elsödleges ellenanyagok}

anti- $\alpha$-aktinin - egérben termelt, felhasznált hígítás: 1:80 (Sigma)

a-DAAM (R4) - nyúlban termelt, felhasznált hígítás: 1:1000 (Matusek és mtsai. 2006)

a-mDaam1 - nyúlban termelt, felhasznált hígítás: 1:2000 (Sigma)

a-mDaam1 - nyúlban termelt, felhasznált hígítás: 1:200 (Abnova)

$\alpha$-EGFP - nyúlban termelt, felhasznált hígítás: 1:1000 (Invitrogen)

a-glikogén-foszforiláz - nyúlban termelt, felhasznált hígítás: 1:20000 (Udvardy A. jóvoltából)

$\alpha$-Kettin - patkányban termelt, felhasznált hígítás: 1:200 (MAC 155, Abcam)

a-Miozin - patkányban termelt, felhasznált hígítás: 1:200 (MAC 147, Abcam)

-Miomezin - egérben termelt, felhasznált hígítás: 1:1 (B4, DSHB)

$\alpha$-Titin - egérben termelt, felhasznált hígítás: 1:20 (9D10, DSHB)

\subsubsection{Felhasznált másodlagos ellenanyagok}

Egérben termelt ellenanyagra specifikus:

a-egér-Al-546, felhasznált hígítás: 1:600 (Invitrogen)

Patkányban termelt ellenanyagra specifikus:

a-patkány-Al-488, felhasznált hígítás: 1:600 (Invitrogen)

a-patkány-A1-647, felhasznált hígítás: 1:600 (Invitrogen)

Nyúlban termelt ellenanyagra specifikus:

ג-nyúl-Al-488, felhasznált hígítás: 1:600 (Invitrogen)

a-nyúl-Al-647, felhasznált hígítás: 1:600 (Invitrogen)

Q-nyúl-HRP-konjugált, felhasznált hígítás 1:10000 


\subsubsection{Felhasznált egyéb reagensek}

Rodamin-falloidin, felhasznált hígítás: 1:50 (Invitrogen)

DAPI $(100 \mu \mathrm{g} / \mathrm{ml})$, felhasznált hígítás: 1:500

\subsection{Lárvális testhossz és mászási sebesség mérések}

A hasonló korú lárvákat legyüjtöttük, csapvízzel mostuk, majd szén és agar tartalmú táplemezre helyeztük őket. A lemezeket az Olympus SZX12 boncoló mikroszkóp alá helyeztük, amely Olympus C7070 digitális kamerával volt ellátva. Teljes megvilágítást használva a felvételeket $25 \mathrm{~Hz}$ frekvencián készítettük. A környezeti tényezők (hőmérséklet, páratartalom, megvilágítás), állandóak voltak. Minden vizsgált lárva mozgásáról 20 másodpercig tartó film készült DScaler (The DScaler Project Team) program segítségével. Ez az időtartam elégségesnek bizonyult ahhoz, hogy a lárvák többsége a látótéren kívül kerüljön. A felvett képsorozatok kiértékelése az ImageJ (NIH) szoftver segítségével valósult meg. A lárvák egyenes vonalú egyenletes mozgását használtuk fel arra, hogy a lárvális testhosszt és a mászási sebességet megmérjük. A lárvális testhosszt a fej és a farok közötti minimális és maximális távolság átlaga alapján számítottuk ki. A lárvális mozgás útvonalát az egymásra szuperponált képekből rekonstruáltuk. A mászási sebességet pedig a megtett út és az eltelt idő hányadosaként számoltuk ki. A vizsgált lárvákat kiboncoltuk, testfal izmaikat immunfestettük, és az összehasonlító mérésekhez izom modellként a 3-as számú ventrális hosszanti testfal izmot (VL3) választottuk. Az izomhossz méréseket manuálisan végeztük a VL3-as izom leghosszabb tengelye mentén. Az izmok szélességét erre merőlegesen, az izom középvonalában mértük. A szarkomer számot és a szarkomer hosszt a falloidinnal festett izmok intenzitás profiljából számoltuk, ahol a szarkomer hossz pontosan megfelelt az intenzitás profilban megjelenő két szomszédos csúcs közötti távolságnak. 


\subsection{Repülési teszt}

A repülési tesztet három napos muslicákon végeztük (Cripps és mtsai. 1994 -ben leírtak szerint). A legyeket egy téglalap alakú átlátszó műanyag doboz oldalának középrészén engedtük be. A doboz fölé fényforrást helyeztünk. A röpképes legyek a középrész fölé vagy azzal egy vonalban szálltak le a doboz falára. A röpképtelenek a középvonal alatti részre vagy a doboz aljára kerültek.

\subsection{Sejtkultúrák és egér izom preparátumok előkészítése}

Az egér miogenikus C2C12 (ATCC) sejtvonalat 10\%-os FBS tartalmú DMEM tápfolyadékban tartottuk fenn (GIBCO/Life Technologies). A sejteket kezdetben $100 \mathrm{~mm}$ átmérôjű csészékbe (Greiner) szélesztettük $10^{4} / \mathrm{cm}^{2}$-es sűrüségben. Amikor a sejttenyészet konfluenciája elérte $\mathrm{a} \sim 80 \%$-os értéket, a sejteket steril üveg fedőlemezekre ültettük ki, majd ezeket 35 mm átmérőjü csészékbe helyeztük. A sejtkultúrákat tápfolyadékban tartottuk, amíg a 60\%-os konfluenciát el nem érték, ezután 2\%-os lószérumot tartalmazó differenciációs médiumba (DMEM; GIBCO/Life Technologies) kerültek. Ezt a médiumot mindennap cseréltük, és a megfelelő időpontokban a mintákat immunfestésre készítettük elő. A fedőlemezeken növesztett sejteket 4\% formaldehid PBS oldatban 10 percig fixáltuk szobahőn, majd háromszor 10 percig PBS-sel mostuk. A mosás után PBS-T-vel 3 percig permeabilizáltuk, majd ismét háromszor 10 perces PBS-sel való mosás következett. Ezután a permeabilizált sejteket PBS+5\% FBS oldatában 1 óráig blokkoltuk szobahőn az immunfestés előtt. Az elsődleges és másodlagos ellenanyagokkal PBS+5\% FBS-ben inkubáltuk 1 órán keresztül szobahőn. A két inkubáció között, illetve az utolsó inkubáció után háromszor 10 perces PBS-sel való mosást iktattunk be. Az utolsó lépések megegyeznek az immunhisztokémiai festésnél leírtakkal. A m. tibialis anterior és m. vastus lateralis izommetszetek készítéséhez C57Bl/6 adult hím egeret használtunk. A 
lábizmokat kiboncoltuk, Tissue-Tek O.C.T. anyagba (Sakura Finetek) ágyaztuk, majd folyékony nitrogénnal hütött izopentánban gyorsfagyasztottuk. A $10 \mu \mathrm{m}$ vastagságú fagyasztott metszeteket elöre lehütött acetonban fixáltuk és $-80^{\circ} \mathrm{C}$-on tároltuk. A további immunhisztokémiai lépések megegyeztek a korábban leírtakkal.

\subsection{Elektronmikroszkópos analízis}

A kiboncolt izmokat $4{ }^{\circ} \mathrm{C}$-on éjszakán át 3,2\% paraformaldehid, 0,5\% glutáraldehid, 1\% szukróz, és $0,028 \% \mathrm{CaCl}_{2}$-ot tartalmazó $0.1 \mathrm{~N}$-os nátrium kakodilát ( $\mathrm{pH}$ 7.4) oldatban fixáltuk, és kétszer mostuk $0.1 \mathrm{~N}$-os nátrium kakodilát ( $\mathrm{pH} 7.4$ ) oldatban éjszakán át $4^{\circ} \mathrm{C}$-on. A mintákat utólagosan is fixáltuk 0,5\%-os ozmium-tetroxidban szobahőn 1 órát, és a gyártó által javasolt protokollnak megfelelően Durcupan (Fluka) mügyantába ágyaztuk. A genotípusonként 2-3 állatból származó 70-80 nm-es ultravékony metszeteket Reynold’s féle ólom citráttal kontrasztosítottuk, majd Morada kamerával felszerelt és iTEM (Olympus) szoftverrel rendelkező JEM 1011 típusú (JEOL) transzmissziós elektronmikroszkóppal vizsgáltuk.

\subsection{Atomerö-mikroszkópos mérések}

Az egyedi miofibrillumokat poly-L-lizinnel bevont tárgylemezekre helyeztük PBS pufferben. A rugalmasság mérési pontok kiválasztása érdekében minden mintáról egy alacsony felbontású topográfiát készítettünk. A mérésekhez egy Asylum MFP-3D fejet és Molecular Force Probe típusú atomerő mikroszkópot (Asylum Research, Santa Barbara, CA) használtunk, melynek vezérlő programja IGOR Pro (5.04-es verzió, Wavemetrics, Lake Oswego, OR) szoftverben készült. Méréseinkhez arannyal bevont szilícium nitridből készült 30pN/nm-es rugóállandójú konzolon elhelyezett, Bio-Lever (BL-RC150 VB-C1, Olympus Optical Co. Ltd) típusú tüket használtunk, melyeknek görbületi sugara $30 \mathrm{~nm}$. Kísérleteinket folyadékban, zárt hurkos visszacsatolású kontakt módban végeztük. A tü függőleges irányú sebessége $0.6 \mu \mathrm{m} / \mathrm{s}(0.1$ 
Hz-es mintavételezési frekvenciával), valamint a minta teljes terhelése $1 \mathrm{nN}$ alatt volt. Erő elmozdulás görbéket készítettünk a következő módon: a tüt a minta felszínéhez közelítettük a beállított elhajlás eléréséig, majd visszahúztuk, miközben a függőleges elmozdulást, valamint a konzol elhajlását mértük. A minta rugalmassági modulusát az erögörbék közelítő ágának kontakt és maximális elhajlási pontok közé eső szakaszából számoltuk, egy kemény felszínen felvett „referencia” görbe levonása után (a Vinckier és Semenza 1998 -ban leírtak szerint). Mintánként a különböző pontokon felvett több erő-benyomódás görbéböl számolt átlagot, valamint a szórást (s.d.) ábrázoltuk.

\subsection{Western-blot}

Az adult IFM mintákat a fent leírtak szerint boncoltuk. A szöveteket rögtön proteáz inhibítort tartalmazó jéghideg RIPA lízis pufferbe helyeztük, és éjszakán át lizáltuk. Az SDS poliakrilamid gélelektroforézis és a Western-blot analízis a standard protokolloknak megfelelően zajlott. A membránokat $\alpha$-DAAM (R4) ellenanyaggal festettük, kontrollként $\alpha$-glikogénfoszforilázt használtunk. Másodlagos ellenanyagként HRP-konjugált $\alpha$-nyúl ellenanyagot használtunk. A membránokat Millipore Immobilon ${ }^{\mathrm{TM}}$ kemilumineszcens detekciós reagenssel hívtuk elő.

\subsection{Az aktin filamentumok vég-vég kapcsolódásának vizsgálata}

Az aktin filamentumok vég-vég kapcsolódásának vizsgálatához fluoreszcens

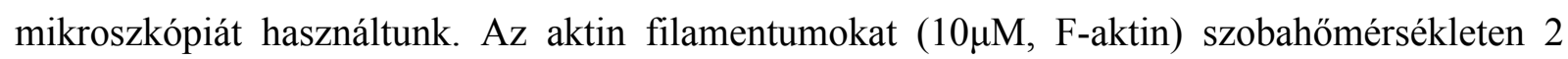
órán keresztül polimerizáltuk a következő F-puffernek nevezett oldatban: 4 mM Tris-HCl, 0,1 $\mathrm{mM} \mathrm{CaCl}_{2}$, 0,2 mM ATP, 0,5 mM DTT, $1 \mathrm{mM} \mathrm{MgCl}_{2}, 50 \mathrm{mM} \mathrm{KCl}$ és $1 \mathrm{mM}$ EGTA pH 7.0. Ezután az F-aktin oldatot F-puffer segítségével 1 $1 \mu \mathrm{M}$-ra hígítottuk a következő aktin kötő fehérjék jelenlétében vagy hiányában: 100 nM capping fehérje, 100 nM dDAAM FH1-FH2 
csonkolt fehérje, $1 \mu \mathrm{M}$ vázizom TM, $100 \mathrm{nM}$ dDAAM FH1-FH2 és $1 \mu \mathrm{M}$ vázizom TM. $\mathrm{A}$ mintákat éjszakán át inkubáltuk, majd egy órán át jelöltük Alexa 488 konjugált falloidinnel, és egy 26G méretü inzulinos fecskendőn átnyomva mechanikailag összetörtük a filamentumokat. Ezt követően a mintákat százszorosára hígítottuk az úgynevezett mikroszkópos pufferben (4 mM Tris-HCl, 1 mM EGTA, 50 mM KCl, 1 mM MgCl2, 0,2 M DTT, 15 mM glükóz, $20 \mu \mathrm{g} / \mathrm{ml}$ kataláz, $100 \mu \mathrm{g} / \mathrm{ml}$ glükóz-oxidáz, $0.5 \%$ (w/v) metilcellulóz, $\mathrm{pH}$ 7,0) a vég-vég kapcsolódás folyamatának leállítására. A kapott képeket ImageJ (NIH) program segítségével kiértékeltük. A 3-4 független kísérlet során megközelítőleg 300-600 filamentum hosszát mértük le egy adott minta esetén, és az átlagos filamentum hosszúságot az idő függvényében ábrázoltuk. A filamentumokat Olympus IX81 inverz fluoreszcens mikroszkóppal vizsgáltuk, 100x objektívet (NA 1.4) és egy CCD kamerát (Orca ERG Hamamatsu) használva. A statisztikai analízishez Microsoft Excel-t vagy Microcal Origin 6.0 programot használtunk.

\subsection{Statisztikai analízis}

Az eredmények számszerüsített adatainak összegyüjtéséhez és kezeléséhez Excel-t (Microsoft) használtunk. A statisztikai analízist Prism 5 (GraphPad Software Inc.) és/vagy SigmaPlot 12 (Systat Software Inc.) szoftverek segítségével végeztük. Az adatok normalitását Shapiro-Wilk teszttel ellenőriztük. A páronkénti összehasonlításokhoz a normalitás függvényében a Student's $t$ tesztet vagy a Mann-Whitney $U$ tesztet használtuk. A p <0,05 értéket statisztikailag szignifikánsnak tekintettük. 


\section{FONTOSABB RÖVIDÍTÉSEK}

$\mathrm{AEL}$ - $\underline{\text { After }}$ Egg $\underline{\text { Laying }}$

AFM - Atomic Force $\underline{\text { Microscope }}$

APF - After Puparium Formation

Arp - Actin-related protein

CC - Coiled-Coil domén

CNS - Central Nervous $\underline{\text { System }}$

Cobl - Cordon-bleu

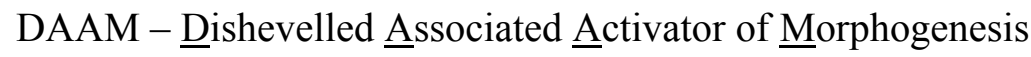

DAD - Diaphanous ㅅutoregulatory Domain

DD - Dimerization Domain

dDAAM - Drosophila DAAM

Dia - Diaphanous

DID - Diaphanous Inhibitory Domain

DLM - Dorsolongitudinal muscle

DRF - Diaphanous related formin

DVM - Dorsoventral muscle

ECM - Extracellular matrix

Ena - Enabled

F-aktin - filamentáris aktin

FH1 - Formin $\underline{\text { Homology } 1}$

FH2 - Formin $\underline{\text { Homology } 2}$

FRL - Formin-related proteins identified in Leukocytes 
G-aktin - globuláris aktin monomer

GBD - GTPase- $\underline{\text { binding }}$ Domain

GFP - Green Fluorescent Protein

IFM - Indirect Flight Muscle

Lmod - Leiomodin

LOF - Loss of Function

MHC - $\underline{\text { Myosin }}$ Heavy $\underline{\text { Chain }}$

MLCK - Myosin Light $\underline{\text { Chain } \underline{\text { Kinase }}}$

NMM - №n- $\underline{\text { muscle Myosin }}$

Obsc - Obscurin

PBS - Phosphate $\underline{B} u f f e r e d ~ \underline{S} a l i n e$

PCP - Planar Cell Polarity

RGD - Arginylglycylaspartic acid

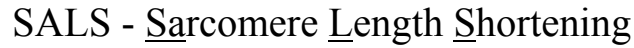

Scar - Suppressor of cAMP receptor

TM - Tropomiozin

Tmod - Tropomodulin

Tn - Troponin

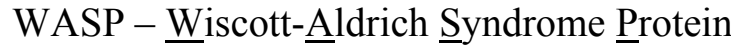

WAVE - WASP-family Verprolin-homologous protein

WH2 - WASP $\underline{\text { Homology } 2}$

ZASP - Z-band alternatively spliced PDZ-motif protein 


\section{7. ÖSSZEFOGLALÁS}

Az izom differenciációt érintő fontos kérdés, hogy a harántcsíkolt izomsejt hogyan képes egy szabályosan ismétlődő, szigorúan rendezett szarkomerekből álló szerkezetet létrehozni a miofibrillogenezis során, más szóval, hogyan zajlik a szarkomer összeszerelődés?

A miofibrillogenezis sok lépésből álló, bonyolult folyamat, és ennek a folyamatnak kitüntetett része a miozin és aktin filamentumok összeszerelődése. Annak ellenére, hogy a szarkomerikus komplexek szerkezeti felépítését sikerült tisztázni, az előbb említett filamentum rendszerek in vivo összeszerelődéséröl keveset tudunk. Különösen arra nem sikerült ez idáig még fényt deríteni, hogy hogyan zajlik a vékony filamentumok kezdeti összeszerelődése, milyen módon megy végbe az aktin dinamika szabályozása, és hogyan szerveződnek a filamentumok a miofibrillogenezis illetve a miofibrillumok fenntartása során. Habár az aktin nukleációs faktorok müködését a különböző modellrendszerekben már régóta tanulmányozzák, az a fehérje, amely a fejlődő izmokban lehetővé tenné a nukleációt, még nem ismeretes. A nukleáción kívül az aktin dinamika fontos összetevői a filamentumok elongációja és a hosszúságuk szabályozása. A harántcsíkolt izmok vékony filamentumainak elongációját tanulmányozva azt találták, hogy a nem-izom sejtekkel ellentétben az in vivo monomer beépülés nem csak a plusz végen történik, hanem a mínusz vég irányából is. Ráadásul az elongáció sebessége nagyobb a mínusz végen, mint a plusz végen. Ez a megfigyelés meglepő, mert a mínusz vég elongáció in vivo teljesen ismeretlen a szakirodalomban, és eddig még nem írtak le mínusz vég elongáló faktorokat.

A dDAAM fehérje lokalizációját vizsgálva megállapítottuk, hogy a fehérje az IFM szarkomerein belül a vékony filamentumok mindkét végén, a Z-korongok és az M-vonal környékén is lokalizálódik. A különböző $d D A A M$ mutánsok esetében az IFM-ben levő dDAAM fehérje szint csökkentésével arányosan nőtt a röpképtelen legyek aránya. A legmarkánsabb 
fenotípust úgy értük el, hogy a részlegesen dDAAM hiányos $d D A A M^{E x I}$-es legyekben csendesítettük a $d D A A M$ gént $\left(d D A A M^{E x l}, U D T\right)$. Western blot analízis segítségével igazoltuk, hogy a röpképtelen fenotípus erőssége megegyezett a dDAAM fehérje szintjének az IFM-ben tapasztalt csökkenésével mind a $d D A A M^{E x I}$-es mind pedig az $d D A A M^{E x I}$, UDT genotípusú állatok esetében. Azt pedig, hogy ezek a fenotípusok valóban a dDAAM szintjének csökkenéséhez köthetőek, a teljes hosszúságú fehérje túltermelésével elvégzett menekítési kísérlettel bizonyítottuk. A legnagyobb dDAAM hiánnyal rendelkező $d D A A M^{E x I}, U D T$ legyek esetében pedig a legsúlyosabb IFM fenotípust figyelhettük meg. Ez az izomrostok egy részének elsorvadását jelentette, a megmaradó miofibrillumok pedig vékonyabbak voltak a vad típusúaknál és a szervezettségüket is elvesztették. A szarkomer hossz rövidülése ezekben a miofibrillumokban elérte a $38 \%$-ot. A bábállapot kialakulásától számított 48 órás $d D A A M^{E x I}$, UDT mutánsok IFM-jében már megfigyelhetőek ugyanazok a fenotípusos elváltozások, amelyeket a fiatal felnőtt állatok esetében tapasztaltunk. Ami azt jelzi, hogy a fenotípus nem a fiatal adultok izmában bekövetkező aránytalan izomösszehúzódás eredménye. A $d D A A M^{E x I}$, UDT mutánsok elektronmikroszkópiás analízisével igazoltuk és kiegészítettük a konfokális mikroszkópia által nyert eredményeket. A konfokális mikroszkópiával készült képeken nem láthattuk, hogy a vékony filamentumokon kívül a vastag filamentum rendszer szerveződése is súlyosan érintett. A vastag filamentumok ritkán párhuzamos lefutásúak, és a számuk kisebb a vad típuséhoz képest, ugyanakkor lazább szerveződésűek. Ennek a laza szerveződésnek a vizsgálatához atomerő mikroszkópiás elemzéseket is végeztünk, amelyek során sikerült kimutatnunk, hogy mind a $d D A A M^{E x I}$ mind a $d D A A M^{E x I}, U D T$ mutánsok miofibrillumainak haránt irányú rugalmassága szignifikánsan alacsonyabb a vad típusénál. A DAAM fehérje lokalizációs megfigyeléseket kiterjesztettük más izmokra is. A fehérjét sikerült detektálni a 
fejlődő és az adult szívcsőben és a lárvális testfal izmokban is. Embrionális és adult korú egér izommetszetek immunfestése után pedig azt tapasztaltuk, hogy az mDaam1 a Drosophila izmokban tapasztalt lokalizációs mintázathoz hasonló képet ad egér izmokban is, ami evolúciós konzerváltságra utal. Másrészt az egér sejtkultúrákban végzett kísérleteink azt mutatták, hogy az mDaam1 a szarkomer kezdeményekben ugyanolyan korán jelenik meg, mint az aktin keresztkötő $\alpha$-aktinin, ami azt jelenti, hogy ennek a forminnak korai szerepe van a miofibrillogenezis során.

A legnagyobb $d D A A M^{E x 68}$ deficiencia allélt hordozó állatok egy része homo- illetve hemizigóta formában elél egészen a harmadik lárvastádiumig. Viszont a 100 órás mutáns lárvák testhossza sokkal rövidebb a vad típusú lárvákéhoz képest. A megfigyeléseink számszerüsítésére kiválasztott 3-as számú ventrális hosszanti testfal izom (VL3) hossza a mutáns lárvákban 53\%kal, a szélessége pedig 38\%-kal csökkent a vad típushoz képest. A VL3-as izmok dDAAM mutánsokban megfigyelhető rövidülése két okra vezethető vissza, egyrészt a szarkomer hossz, másrészt a szarkomer szám is csökken ezekben a mutánsokban. A 100 órás mutáns lárvák mászási sebessége $\sim 60 \%$-kal csökkent a vad típushoz képest. Western blot analízissel kimutattuk, hogy az IFM-ben két különböző dDAAM izoforma expresszálódik: egy rövid (130 kD-os) és egy hosszú (163 kD), nagyobb mennyiségben jelen levő izoforma. Ezek méretük alapján megfelelnek a Flybase adatbázis által prediktált DAAM-PB (rövid izoforma), illetve DAAM-PD (hosszú izoforma) fehérjéknek. A menekítési kísérleteket külön elvégeztük mindkét izoformával. Az $U A S-D A A M-P B$ expresszió a $d D A A M^{E x 68}$-as lárvák sebességvesztését csak részben, míg a testhosszát és izomméretét majdnem teljes mértékben menekíteni tudta. Az UAS$D A A M-P D$ expressziónak pedig sikerült majdnem teljesen helyreállítania a vad típusra jellemző fenotípusos értékeket. A vad típusú konstrukciókkal ellentétben az aktin polimerizációra képtelen mutáns formák, az $U A S-D A A M-P B^{I 732 A}$ és az $U A S-D A A M-P D^{I 1042 A}$, nem menekítették a 
fenotípust. Söt, az $U A S-D A A M-P D^{I 1042 A}$ túltermelve domináns negatív formaként viselkedett a testhossz és a sebesség menekítése esetében. A mutáns háttéren végzett kísérleteken kívül a dDAAM konstrukciók vad típusú genetikai háttéren való túltermelését is elvégeztük. Az UAS$D A A M-P B$ és az $U A S-D A A M-P D$ vad háttéren végzett izom-specifikus túltermelése a vad típusra jellemző testhossznál szignifikánsan hosszabb lárvákat eredményezett. Az izmok meghosszabbodásához az vezetett, hogy mindkét izoforma túltermelése esetén a szarkomerek száma szignifikánsan megnőtt a vad típushoz képest. Érdekes adat, hogy a PB izoformát túltermelő lárvák 55\%-al gyorsabban mozogtak a vad típusú társaiknál. A 100 órás $d D A A M^{E x 68}$ mutáns lárvák csökkent testméretével összhangban a szívcsövük átméröje $\sim 40 \%$-kal kisebb a vad típushoz képest.

A $d D A A M$ és az IFM specifikus $A c t 88 F^{K M 88}$ és $T m 2^{3}$ allélok között erös genetikai kölcsönhatást találtunk, nem-izom sejt típusú izoformákkal pedig nem volt interakció, ami azt bizonyította, hogy a dDAAM fehérje funkciója az izomfejlődés során a szarkomerikus aktin filamentumok kialakításához kötődik.

Ahhoz, hogy kiderítsük, hogy a dDAAM fehérjének van-e szerepe a vékony filamentumok mínusz vég felőli növekedésében, genetikai interakciós kísérleteket végeztünk két bizonyítottan mínusz vég szabályozó fehérje mutáns alléljaival, a SALS-al és a Tmod-al. A sals $^{f 07849} /+$ a $d D A A M^{E x I}$-es mutáns háttéren nem okozott fenotípusbeli változást. Ezzel szemben a $\operatorname{tmod}^{00848}$ mutáció teljes mértékben szupresszálta a $d D A A M^{E x I}$ mutáns gyenge röpképtelen fenotípusát, visszaállítva a vad típushoz közeli értéket. Kimutattuk azt is, hogy az alacsonyabb dDAAM fehérjeszint szupresszálja a vékony filamentumok „túlnövekedési” fenotípusát, amelyet a tmod ${ }^{R N S i}$ muslicák indirekt repülőizmában láttunk. 
Habár a dDAAM fehérje a szarkomerikus vékony filamentumok mínusz vége közelében is lokalizálódik, korábbi szerkezeti vizsgálatok azt jelzik, hogy a forminok kizárólag plusz vég kötő fehérjék. Ennek az ellentmondásnak a feloldására teszünk javaslatot egy olyan modellel, amelyben a mínusz vég felöli elongáció rövid aktin fragmentumok képződésén alapul, amelyek fokozatosan, oligomerként épülnek be a plusz végükkel a Z-koronghoz rögzített növekvő filamentumokba. Ebben a feltételezett modellben a dDAAM klasszikus plusz vég kötő fehérjeként müködve rövid aktin fragmentumokat hozna létre, de emellett aktív módon is elősegítené a fragmentumok beépülését, vagy legalábbis nem gátolná azt. Hogy ezt a feltételezést igazolni tudjuk, egy in vitro F-aktin végillesztő aktivitási vizsgálatot végeztünk, melyben a dDAAM plusz vég kötö FH1-FH2 doménjeit használtuk. Azt találtuk, hogy az FH1-FH2 domén 100nM-os koncentrációban nem gátolta az aktin filamentumok végeinek az összeolvadását.

Az $m h c$ és a $d D A A M$ között az életképességet és az izomszerkezetet érintő domináns genetikai kölcsönhatást találtunk, ami arra utal, hogy a dDAAM az MHC fehérjével összehangoltan müködik az izomfejlődés során, és úgy tünik, hogy ez a kölcsönhatás a $d D A A M$ aktin szabályozó funkciójától független. A $d D A A M^{E x I} ; z i p^{2} /+$ kettős mutánsok esetében tapasztalt csökkent életképesség pedig azzal magyarázható, hogy a miozin/dDAAM kölcsönhatás a nemizom sejtekben is fontos szerepet játszik.

Összefoglalásként elmondható, hogy a formin típusú fehérjékhez tartozó Drosophila DAAM részt vesz a vékony filamentumok kezdeti összeszerelődésében, illetve a vastag filamentumokkal való kölcsönhatás eredményeként a szarkomer szerveződésben is. Ezért a DAAM alcsaládba tartozó fehérjék jó jelöltnek tünnek a régóta keresett izom típusú nukleációs és elongációs faktorok szerepére. 


\section{SUMMARY}

The initial step of myofibril assembly is the formation of a regular array of sarcomeres. These sarcomeres later grow in width and in some cases in length, and eventually align and attach to each other and the sarcolemma. An important question in muscle differentiation is how the striated muscle cell produces these myofibrils with such regular arrays of sarcomeres. Whereas the structural properties of the sarcomeric complexes have been resolved in remarkable details over the past decades, much less is known as to how these cytoskeletal filament systems assemble in vivo. In particular, the initial assembly of thin filaments, the regulation of actin dynamics and organization during myofibril formation and maintenance remained poorly understood. Although the actin nucleation factors are heavily studied in a number of different model systems, the essential nucleation factors in developing muscles have so far not been clearly identified.

Besides nucleation, the other important aspects of actin dynamics are filament elongation and length regulation. It is thought that actin filament growth is primarily controlled by two antagonistically acting family of proteins, elongation factors and capping proteins. The elongation factors promote barbed end growth, whereas binding of the capping proteins block polymerization. The barbed and pointed ends of muscle thin filaments are lined up in regular arrays within each sarcomere. Contrasting to the situation in non-muscle cells where filament growth is restricted to the barbed end, sarcomeric actin filaments are thought to elongate from their pointed ends during myofibril assembly, although actin turnover is clearly evident at the barbed end as well. Because there is no protein isolated yet from any cell type that would catalyze actin assembly at the pointed end, the mechanism that enables muscle thin filament assembly, including the elongation from their pointed end, remained mysterious. 
Our latest results revealed that, beyond its role in non-muscle cells, $\triangle D A A M$ plays a pivotal role in sarcomerogenesis. The dDAAM protein is enriched in several different types of muscles including the larval body wall muscles, the indirect flight muscle (IFM) and the heart tube. Our protein localization data are consistent with the idea that, although being a barbed end binding protein in non-muscle cells, dDAAM is both enriched in the vicinity of the barbed and pointed ends of the thin filaments in muscle cells. The lack of dDAAM causes a flightless phenotype, as $16 \%$ of adults homozygous for the viable, hypomorphic $d D A A M^{E x I}$ allele were flightless. Because $d D A A M$ null alleles are homozygous lethal, we used two $d D A A M$ specific RNAi lines (KK102786 from VDRC and T129M constructed in our laboratory, targeting two non-overlapping parts of the mRNA) to verify the flight effect. In the presence of UAS-Dicer2 and an IFM (indirect flight muscle) specific driver (UH3-Gal4), both RNAi lines produced strong flightless phenotypes. RNAi silencing in a $d D A A M$ mutant background ( $D D A A M^{E x I}, U H 3$ Gal4; UAS-Dicer2; UAS-dDAAM $M^{R N A i-T 129 M}$, subsequently referred to as $\left.d D A A M^{E x I}, U D T\right)$ caused nearly all males to be flightless. As we could show by the use of the Western blot analysis, the strength of the flightless phenotypes correlated with the partial reduction of dDAAM protein levels in $d D A A M^{E x I}$ IFM and its near absence in IFM from the RNAi genotypes. The flightless phenotype exhibited by $d D A A M^{E x I}$ mutants could be rescued by muscle-specific expression of the dDAAM protein.

The IFM from the $d D A A M^{E x l}$, UDT mutant combination showed the worst alterations in IFM fiber morphology. The myofibrils were thinner than in wild type and their organization was irregular. Mutant IFMs exhibited reduced F-actin staining without significant alterations in the amount of G-actin (showed by Coomassie staining). Additionally, phalloidin staining suggested that many of the thin filaments were of unequal length, and similar to $d D A A M^{E x I}$ mutants, shorter 
sarcomeres could often be detected. The sarcomere length reduction in these myofibrils reached even 38\%. M-lines could hardly be identified by Myosin immunostaining, while the Z-discs displayed a highly irregular and delocalized pattern compared to wild type. Thus, loss of $d D A A M$ function impairs IFM structure from overall muscle shape to myofibrillar and sarcomeric organization. At 48 hours after puparium formation (APF) $\left(\right.$ at $\left.29^{\circ} \mathrm{C}\right)$ the pupal IFM of $d D A A M^{E x I}, U D T$ flies already showed all the muscle phenotypes observed in adults. These include irregular myofibrillar organization, reduced F-actin levels, lack of visible M-lines, disorganized, unequally spaced Z-discs and sarcomere shortening. These data suggest that the IFM phenotypes observed in newly hatched $D D A A M$ mutant adults were likely to be a consequence of loss of $d D A A M$ function during early muscle development. Electron microscopy (EM) of the IFM of $d D A A M^{E x I}$, UDT mutants confirmed and extended all the major myofibrillar defects seen in the confocal images. We could not detect with confocal microscopy that thick filaments rarely ran parallel to each other, the average thick filament number per sarcomere was strongly reduced compared to controls, and filament packing was much looser than wild type. To test whether the structural alterations observed in $d D A A M$ mutant myofibrils affect their mechanical properties an Atomic Force Microscope (AFM) was used to measure the transverse elasticity of individual myofibrils in rigor conditions. The elasticity (Young's modulus) of $d D A A M^{E x I}$ and $d D A A M^{E x l}$, $U D T$ mutant myofibrils was significantly lower than that of wild type.

The subsarcomeric localization of mDaam1 appears similar to that of Drosophila DAAM with regard to accumulation at the Z-disc and alongside the M-line, and this suggests an evolutionary conserved function. On the other hand, our experiments done on mice cell cultures 
showed, that mDaam1 is recruited to sarcomeric complexes as early as the actin crosslinker $\alpha$ actinin protein. Therefore this formin is likely to be an early determinant of myofibrillogenesis.

To ask whether $d D A A M$ plays a role generally in muscle development, larval body wall muscles and the heart tube were examined. The body size and somatic musculature of $d D A A M^{E x 68}$ null mutant early third instar (L3) appeared normal, but late in L3, 100 hours after eggs laying (AEL), the larvae were shorter than wild type. Measurements of the ventral longitudinal 3 (VL3) muscle showed a 53\% length reduction and 38\% width reduction in the mutants. Shortening of VL3 in $d D A A M$ mutants arises both by sarcomere shortening and a reduction in sarcomere numbers. To investigate the physiological relevance of the muscular defects observed, we examined the larval motility of $d D A A M$ mutant larvae. At 100 hours AEL their velocity was decreased by $60 \%$ compared to wild type. Western blot analysis revealed that the IFM expresses two dDAAM protein isoforms, a short $(130 \mathrm{kD})$ minor isoform and a long $(163 \mathrm{kD})$ major isoform. These correspond respectively to the predicted DAAM-PB and DAAMPD proteins (Flybase annotation). The rescue experiments were performed with $U A S-D A A M-P B$ as well as with $U A S-D A A M-P D$. UAS-DAAM-PB expression partly rescued the velocity decrease and almost fully rescued the body and muscle size of $d D A A M^{E x 68}$ mutant larvae, whereas $U A S$ $D A A M-P D$ expression almost completely rescued all the phenotypic traits. Unlike the wild type constructs, the actin polymerization incompetent mutant forms, $U A S-D A A M-P B^{I 732 A}$ and $U A S$ $D A A M-P D^{I 1042 A}$ mimicking the Bni1 I1431A mutation, failed to rescue. Muscle-specific expression of $U A S-D A A M-P B$ and $U A S-D A A M-P D$, in a wild type background, produced significantly longer larvae than wild type. Muscle lengthening occurred by significantly increasing the sarcomere number. Interestingly, larvae expressing the PB isoform were 55\% 
faster than wild type larvae. Larval heart tube size was also reduced in 100 hour old $d D A A M^{E x 68}$ mutants compared to wild type ( $40 \%$ reduction in diameter).

The strong dominant genetic interaction between $d D A A M$ and the IFM-specific Act $88 F$ and $\operatorname{Tm} 2$ alleles, and the complete lack of interaction with the non-muscle cell specific isoforms, suggests that the major function of dDAAM during muscle development is linked to the regulation of sarcomeric actin filament formation. To determine whether dDAAM is functionally important for pointed end elongation we investigated genetic interactions of $D D A A M$ with mutations affecting the pointed end regulator proteins SALS and Tmod. The presence of sals $s^{f 07849} /+$ in a $d D A A M^{E x I}$ mutant background had no obvious phenotypic effect. In contrast, the tmod $^{00848}$ mutation entirely suppressed the weak flightless phenotype of $d D A A M^{E x l}$, suggesting that dDAAM and Tmod may act antagonistically during thin filament growth. We also showed, that the reduced dDAAM levels suppress the "over elongation" of the thin filaments seen in the IFM of tmodRNAi flies. Although dDAAM protein is detected in the vicinity of the pointed ends of sarcomeric thin filaments, former structural studies indicated that formins are strictly barbed end binding proteins. This paradox would be resolved if pointed end elongation relies on the formation of short actin filaments that anneal sequentially to growing thin filaments anchored to the Z-disc. In this model, dDAAM would mediate the assembly of short actin filaments by acting as a classical barbed end binding formin, but would additionally either actively promote actin filament annealing, or at least not block it. To test this expectation, an in vitro F-actin annealing assay was carried out with the barbed end binding FH1-FH2 domains of dDAAM. We found that the presence of the FH1-FH2 fragment (100 nM) allowed the end-to end annealing of actin filaments. 
The dominant genetic interactions between $m h c$ and $d D A A M$ with respect to viability and muscle structure support the possibility that dDAAM acts in concert with Mhe during muscle development, and this interaction seems to be largely independent form the actin regulatory function of $d D A A M$. And the strongly reduced viability of the $d D A A M^{E x l} ; z i p^{2} /+$ double mutants is best explained by assuming that the myosin/dDAAM interactions are important in non-muscle cells as well.

In conclusion, our results indicated that, beyond a role in actin regulation, $D D A A M$ might also be required for the proper formation of the thick filaments and/or the integration of the major filamental systems into the greatly organized myofibrils. Therefore we propose that members of the DAAM family of formins are very good candidates for the long sought-after muscle actin/thin filament nucleators. 


\section{IRODALOMJEGYZÉK}

Agbulut, O., Noirez, P., Beaumont, F. and Butler-Browne, G. (2003). Myosin heavy chain isoforms in postnatal muscle development of mice. Biol. Cell 95, 399-406.

Ahern-Djamali, S. M., Bachmann, C., Hua, P., Reddy, S. K., Kastenmeier, A. S., Walter, U. and Hoffmann, F. M. (1999). Identification of profilin and src homology 3 domains as binding partners for Drosophila enabled. Proc. Natl. Acad. Sci. U. S. A. 96, 4977-82.

Alberts, B., Johnson, A., Lewis, J., Raff, M., Roberts, K. and Walter, P. (2002). Molecular Biology of the Cell, 4th Edition.

Andrianantoandro, E., Blanchoin, L., Sept, D., McCammon, J. A. and Pollard, T. D. (2001). Kinetic mechanism of end-to-end annealing of actin filaments. J. Mol. Biol. 312, 721-30.

Ang, S.-F., Zhao, Z., Lim, L. and Manser, E. (2010). DAAM1 is a formin required for centrosome re-orientation during cell migration. PLoS One 5,

Au, Y. (2004). The muscle ultrastructure: a structural perspective of the sarcomere. Cell. Mol. Life Sci. 61, 3016-33.

Bai, J., Hartwig, J. H. and Perrimon, N. (2007). SALS, a WH2-domain-containing protein, promotes sarcomeric actin filament elongation from pointed ends during Drosophila muscle growth. Dev. Cell 13, 828-42.

Bang, M.-L., Li, X., Littlefield, R., Bremner, S., Thor, A., Knowlton, K. U., Lieber, R. L. and Chen, J. (2006). Nebulin-deficient mice exhibit shorter thin filament lengths and reduced contractile function in skeletal muscle. J. Cell Biol. 173, 905-16.

Barkó, S., Bugyi, B., Carlier, M.-F., Gombos, R., Matusek, T., Mihály, J. and Nyitrai, M. (2010). Characterization of the biochemical properties and biological function of the formin homology domains of Drosophila DAAM. J. Biol. Chem. 285, 13154-69.

Bartolini, F., Moseley, J. B., Schmoranzer, J., Cassimeris, L., Goode, B. L. and Gundersen, G. G. (2008). The formin mDia2 stabilizes microtubules independently of its actin nucleation activity. J. Cell Biol. 181, 523-36.

Bate, M. (1990). The embryonic development of larval muscles in Drosophila. Development 110, 791-804.

Bate, M. and Martinez Arias, A. (1993). The Development of Drosophila melanogaster, Cold Spring Harbor Laboratory Press, Cold Spring Harbor. 2, pp. 1013-1090.

Bate, M., Rushton, E. and Currie, D. A. (1991). Cells with persistent twist expression are the embryonic precursors of adult muscles in Drosophila. Development 113, 79-89. 
Beall, C. J., Sepanski, M. A. and Fyrberg, E. A. (1989). Genetic dissection of Drosophila myofibril formation: effects of actin and myosin heavy chain null alleles. Genes Dev. 3, $131-40$.

Blanchoin, L., Amann, K. J., Higgs, H. N., Marchand, J. B., Kaiser, D. A. and Pollard, T. D. (2000). Direct observation of dendritic actin filament networks nucleated by Arp2/3 complex and WASP/Scar proteins. Nature 404, 1007-11.

Brand-Saberi, B. (2005). Genetic and epigenetic control of skeletal muscle development. Ann. Anat. 187, 199-207.

Campellone, K. G. and Welch, M. D. (2010). A nucleator arms race: cellular control of actin assembly. Nat. Rev. Mol. Cell Biol. 11, 237-51.

Chalkia, D., Nikolaidis, N., Makalowski, W., Klein, J. and Nei, M. (2008). Origins and evolution of the formin multigene family that is involved in the formation of actin filaments. Mol. Biol. Evol. 25, 2717-33.

Chang, F., Drubin, D. and Nurse, P. (1997). cdc12p, a protein required for cytokinesis in fission yeast, is a component of the cell division ring and interacts with profilin. J. Cell Biol. 137, 169-82.

Chereau, D., Boczkowska, M., Skwarek-Maruszewska, A., Fujiwara, I., Hayes, D. B., Rebowski, G., Lappalainen, P., Pollard, T. D. and Dominguez, R. (2008). Leiomodin is an actin filament nucleator in muscle cells. Science 320, 239-43.

Chesarone, M. a and Goode, B. L. (2009). Actin nucleation and elongation factors: mechanisms and interplay. Curr. Opin. Cell Biol. 21, 28-37.

Chhabra, E. S. and Higgs, H. N. (2006). INF2 Is a WASP homology 2 motif-containing formin that severs actin filaments and accelerates both polymerization and depolymerization. $J$. Biol. Chem. 281, 26754-67.

Chow, D., Srikakulam, R., Chen, Y. and Winkelmann, D. A. (2002). Folding of the striated muscle myosin motor domain. J. Biol. Chem. 277, 36799-807.

Clark, K. A., McElhinny, A. S., Beckerle, M. C. and Gregorio, C. C. (2002). Striated muscle cytoarchitecture: an intricate web of form and function. Annu. Rev. Cell Dev. Biol. 18, 637706.

Colombo, A., Palma, K., Armijo, L., Mione, M., Signore, I. A., Morales, C., Guerrero, N., Meynard, M. M., Pérez, R., Suazo, J., et al. (2013). Daam1a mediates asymmetric habenular morphogenesis by regulating dendritic and axonal outgrowth. Development 140, 3997-4007. 
Cooper, J. A., Walker, S. B. and Pollard, T. D. (1983). Pyrene actin: documentation of the validity of a sensitive assay for actin polymerization. J. Muscle Res. Cell Motil. 4, 253-62.

Copeland, J. W., Copeland, S. J. and Treisman, R. (2004). Homo-oligomerization is essential for F-actin assembly by the formin family FH2 domain. J. Biol. Chem. 279, 50250-6.

Cripps, R. M., Ball, E., Stark, M., Lawn, A. and Sparrow, J. C. (1994). Recovery of dominant, autosomal flightless mutants of Drosophila melanogaster and identification of a new gene required for normal muscle structure and function. Genetics 137, 151-64.

Currie, D. A. and Bate, M. (1991). The development of adult abdominal muscles in Drosophila: myoblasts express twist and are associated with nerves. Development 113, 91-102.

Demontis, F. and Perrimon, N. (2009). Integration of Insulin receptor/Foxo signaling and dMyc activity during muscle growth regulates body size in Drosophila. Development 136, 983-93.

Dietzl, G., Chen, D., Schnorrer, F., Su, K.-C., Barinova, Y., Fellner, M., Gasser, B., Kinsey, K., Oppel, S., Scheiblauer, S., et al. (2007). A genome-wide transgenic RNAi library for conditional gene inactivation in Drosophila. Nature 448, 151-6.

Dominguez, R. (2009). Actin filament nucleation and elongation factors--structure-function relationships. Crit. Rev. Biochem. Mol. Biol. 44, 351-66.

Ehler, E. and Gautel, M. (2008). The sarcomere and sarcomerogenesis. Adv. Exp. Med. Biol. 642, 1-14.

Ervasti, J. M. (2003). Costameres: the Achilles' heel of Herculean muscle. J. Biol. Chem. 278, $13591-4$.

Etard, C., Behra, M., Fischer, N., Hutcheson, D., Geisler, R. and Strähle, U. (2007). The UCS factor Steif/Unc-45b interacts with the heat shock protein Hsp90a during myofibrillogenesis. Dev. Biol. 308, 133-43.

Etard, C., Roostalu, U. and Strähle, U. (2008). Shuttling of the chaperones Unc45b and Hsp90a between the A band and the Z line of the myofibril. J. Cell Biol. 180, 1163-75.

Evangelista, M., Blundell, K., Longtine, M. S., Chow, C. J., Adames, N., Pringle, J. R., Peter, M. and Boone, C. (1997). Bnilp, a yeast formin linking cdc42p and the actin cytoskeleton during polarized morphogenesis. Science 276, 118-22.

Evangelista, M., Zigmond, S. and Boone, C. (2003). Formins: signaling effectors for assembly and polarization of actin filaments. J. Cell Sci. 116, 2603-11.

Fernandes, J., Bate, M. and Vijayraghavan, K. (1991). Development of the indirect flight muscles of Drosophila. Development 113, 67-77. 
Fritz-Six, K. L., Cox, P. R., Fischer, R. S., Xu, B., Gregorio, C. C., Zoghbi, H. Y. and Fowler, V. M. (2003). Aberrant myofibril assembly in tropomodulin1 null mice leads to aborted heart development and embryonic lethality. J. Cell Biol. 163, 1033-44.

Fyrberg, E. A., Mahaffey, J. W., Bond, B. J. and Davidson, N. (1983). Transcripts of the six Drosophila actin genes accumulate in a stage- and tissue-specific manner. Cell 33, 115-23.

Goley, E. D. and Welch, M. D. (2006). The ARP2/3 complex: an actin nucleator comes of age. Nat. Rev. Mol. Cell Biol. 7, 713-26.

Gonçalves-Pimentel, C., Gombos, R., Mihály, J., Sánchez-Soriano, N. and Prokop, A. (2011). Dissecting regulatory networks of filopodia formation in a Drosophila growth cone model. PLoS One 6, e18340.

Goode, B. L. and Eck, M. J. (2007). Mechanism and function of formins in the control of actin assembly. Annu. Rev. Biochem. 76, 593-627.

Grove, B. K., Kurer, V., Lehner, C., Doetschman, T. C., Perriard, J. C. and Eppenberger, H. M. (1984). A new 185,000-dalton skeletal muscle protein detected by monoclonal antibodies. J. Cell Biol. 98, 518-24.

Grunt, M., Zárský, V. and Cvrcková, F. (2008). Roots of angiosperm formins: the evolutionary history of plant FH2 domain-containing proteins. BMC Evol. Biol. 8, 115.

Gunning, P. (2008). Emerging issues for tropomyosin structure, regulation, function and pathology. Adv. Exp. Med. Biol. 644, 293-8.

Habas, R., Kato, Y. and He, X. (2001). Wnt/Frizzled activation of Rho regulates vertebrate gastrulation and requires a novel Formin homology protein Daam1. Cell 107, 843-54.

Haffner, C., Jarchau, T., Reinhard, M., Hoppe, J., Lohmann, S. M. and Walter, U. (1995). Molecular cloning, structural analysis and functional expression of the proline-rich focal adhesion and microfilament-associated protein VASP. EMBO J. 14, 19-27.

Harris, E. S. and Higgs, H. N. (2006). Biochemical analysis of mammalian formin effects on actin dynamics. Methods Enzymol. 406, 190-214.

Harris, E. S., Li, F. and Higgs, H. N. (2004). The mouse formin, FRLalpha, slows actin filament barbed end elongation, competes with capping protein, accelerates polymerization from monomers, and severs filaments. J. Biol. Chem. 279, 20076-87.

Harris, E. S., Rouiller, I., Hanein, D. and Higgs, H. N. (2006). Mechanistic differences in actin bundling activity of two mammalian formins, FRL1 and mDia2. J. Biol. Chem. 281, 14383-92. 
Heuson-Stiennon, J. (1965). Morphogenése de la cellule musculaire striée, étudiée au microscope électronique. I. Formation des structures fibrillaires. J. Microsc. I., 657-678.

Higashi, T., Ikeda, T., Shirakawa, R., Kondo, H., Kawato, M., Horiguchi, M., Okuda, T., Okawa, K., Fukai, S., Nureki, O., et al. (2008). Biochemical characterization of the Rho GTPase-regulated actin assembly by diaphanous-related formins, mDia1 and Daam1, in platelets. J. Biol. Chem. 283, 8746-55.

Higgs, H. N. (2005). Formin proteins: a domain-based approach. Trends Biochem. Sci. 30, 34253.

Higgs, H. N. and Peterson, K. J. (2005). Phylogenetic analysis of the formin homology 2 domain. Mol. Biol. Cell 16, 1-13.

Holtzer, H., Hijikata, T., Lin, Z. X., Zhang, Z. Q., Holtzer, S., Protasi, F., FranziniArmstrong, C. and Sweeney, H. L. (1997). Independent assembly of 1.6 microns long bipolar MHC filaments and I-Z-I bodies. Cell Struct. Funct. 22, 83-93.

Hudson, A. M., Petrella, L. N., Tanaka, A. J. and Cooley, L. (2008). Mononuclear muscle cells in Drosophila ovaries revealed by GFP protein traps. Dev. Biol. 314, 329-40.

Imamura, H., Tanaka, K., Hihara, T., Umikawa, M., Kamei, T., Takahashi, K., Sasaki, T. and Takai, Y. (1997). Bnilp and Bnrlp: downstream targets of the Rho family small Gproteins which interact with profilin and regulate actin cytoskeleton in Saccharomyces cerevisiae. EMBO J. 16, 2745-55.

Iskratsch, T., Lange, S., Dwyer, J., Kho, A. L., dos Remedios, C. and Ehler, E. (2010). Formin follows function: a muscle-specific isoform of FHOD3 is regulated by CK2 phosphorylation and promotes myofibril maintenance. J. Cell Biol. 191, 1159-72.

Ju, R., Cirone, P., Lin, S., Griesbach, H., Slusarski, D. C. and Crews, C. M. (2010). Activation of the planar cell polarity formin DAAM1 leads to inhibition of endothelial cell proliferation, migration, and angiogenesis. Proc. Natl. Acad. Sci. U. S. A. 107, 6906-11.

Kaiser, D. A., Vinson, V. K., Murphy, D. B. and Pollard, T. D. (1999). Profilin is predominantly associated with monomeric actin in Acanthamoeba. J. Cell Sci. 112 ( Pt 2, 3779-90.

Kan-O, M., Takeya, R., Abe, T., Kitajima, N., Nishida, M., Tominaga, R., Kurose, H. and Sumimoto, H. (2012). Mammalian formin Fhod3 plays an essential role in cardiogenesis by organizing myofibrillogenesis. Biol. Open 1, 889-96.

Karlik, C. C. and Fyrberg, E. A. (1985). An insertion within a variably spliced Drosophila tropomyosin gene blocks accumulation of only one encoded isoform. Cell 41, 57-66. 
Katzemich, A., Kreisköther, N., Alexandrovich, A., Elliott, C., Schöck, F., Leonard, K., Sparrow, J. and Bullard, B. (2012). The function of the M-line protein obscurin in controlling the symmetry of the sarcomere in the flight muscle of Drosophila. J. Cell Sci. 125, 3367-79.

Kelly, D. E. (1969). Myofibrillogenesis and Z-band differentiation. Anat. Rec. 163, 403-25.

Kida, Y., Shiraishi, T. and Ogura, T. (2004). Identification of chick and mouse Daam1 and Daam2 genes and their expression patterns in the central nervous system. Brain Res. Dev. Brain Res. 153, 143-50.

Kim, J., Löwe, T. and Hoppe, T. (2008). Protein quality control gets muscle into shape. Trends Cell Biol. 18, 264-72.

Kitzing, T. M., Sahadevan, A. S., Brandt, D. T., Knieling, H., Hannemann, S., Fackler, O. T., Grosshans, J. and Grosse, R. (2007). Positive feedback between Dia1, LARG, and RhoA regulates cell morphology and invasion. Genes Dev. 21, 1478-83.

Komiya, Y. and Habas, R. (2008). Wnt signal transduction pathways. Organogenesis 4, 68-75.

Kontrogianni-Konstantopoulos, A., Catino, D. H., Strong, J. C. and Bloch, R. J. (2006). De novo myofibrillogenesis in $\mathrm{C} 2 \mathrm{C} 12$ cells: evidence for the independent assembly of $\mathrm{M}$ bands and Z disks. Am. J. Physiol. Cell Physiol. 290, C626-37.

Kovar, D. R., Kuhn, J. R., Tichy, A. L. and Pollard, T. D. (2003). The fission yeast cytokinesis formin Cdc12p is a barbed end actin filament capping protein gated by profilin. J. Cell Biol. 161, 875-87.

Krone, P. H., Evans, T. G. and Blechinger, S. R. (2003). Heat shock gene expression and function during zebrafish embryogenesis. Semin. Cell Dev. Biol. 14, 267-74.

LeClaire, L. L., Baumgartner, M., Iwasa, J. H., Mullins, R. D. and Barber, D. L. (2008). Phosphorylation of the Arp2/3 complex is necessary to nucleate actin filaments. J. Cell Biol. 182, 647-54.

Lee, Y. S. and Carthew, R. W. (2003). Making a better RNAi vector for Drosophila: use of intron spacers. Methods 30, 322-9.

Lee, H. K. and Deneen, B. (2012). Daam2 is required for dorsal patterning via modulation of canonical Wnt signaling in the developing spinal cord. Dev. Cell 22, 183-96.

Levitsky, D. I., Khvorov, N. V, Shnyrov, V. L., Vedenkina, N. S., Permyakov, E. A. and Poglazov, B. F. (1990). Domain structure of myosin subfragment-1. Selective denaturation of the $50 \mathrm{kDa}$ segment. FEBS Lett. 264, 176-8. 
Lewkowicz, E., Herit, F., Le Clainche, C., Bourdoncle, P., Perez, F. and Niedergang, F. (2008). The microtubule-binding protein CLIP-170 coordinates mDial and actin reorganization during CR3-mediated phagocytosis. J. Cell Biol. 183, 1287-98.

Li, F. and Higgs, H. N. (2003). The mouse Formin mDia1 is a potent actin nucleation factor regulated by autoinhibition. Curr. Biol. 13, 1335-40.

Li, F. and Higgs, H. N. (2005). Dissecting requirements for auto-inhibition of actin nucleation by the formin, mDia1. J. Biol. Chem. 280, 6986-92.

Li, D., Hallett, M. A., Zhu, W., Rubart, M., Liu, Y., Yang, Z., Chen, H., Haneline, L. S., Chan, R. J., Schwartz, R. J., et al. (2011). Dishevelled-associated activator of morphogenesis 1 (Daam1) is required for heart morphogenesis. Development 138, 303-15.

Lin, Z., Lu, M. H., Schultheiss, T., Choi, J., Holtzer, S., DiLullo, C., Fischman, D. A. and Holtzer, H. (1994). Sequential appearance of muscle-specific proteins in myoblasts as a function of time after cell division: evidence for a conserved myoblast differentiation program in skeletal muscle. Cell Motil. Cytoskeleton 29, 1-19.

Littlefield, R. S. and Fowler, V. M. (2008). Thin filament length regulation in striated muscle sarcomeres: pointed-end dynamics go beyond a nebulin ruler. Semin. Cell Dev. Biol. 19, $511-9$.

Littlefield, R., Almenar-Queralt, A. and Fowler, V. M. (2001). Actin dynamics at pointed ends regulates thin filament length in striated muscle. Nat. Cell Biol. 3, 544-51.

Liu, W., Sato, A., Khadka, D., Bharti, R., Diaz, H., Runnels, L. W. and Habas, R. (2008a). Mechanism of activation of the Formin protein Daam1. Proc. Natl. Acad. Sci. U. S. A. 105, $210-5$.

Liu, L., Srikakulam, R. and Winkelmann, D. A. (2008b). Unc45 activates Hsp90-dependent folding of the myosin motor domain. J. Biol. Chem. 283, 13185-93.

LoRusso, S. M., Rhee, D., Sanger, J. M. and Sanger, J. W. (1997). Premyofibrils in spreading adult cardiomyocytes in tissue culture: evidence for reexpression of the embryonic program for myofibrillogenesis in adult cells. Cell Motil. Cytoskeleton 37, 183-98.

Lu, J., Meng, W., Poy, F., Maiti, S., Goode, B. L. and Eck, M. J. (2007). Structure of the FH2 domain of Daam1: implications for formin regulation of actin assembly. J. Mol. Biol. 369, $1258-69$.

Lymn, R. W. and Taylor, E. W. (1971). Mechanism of adenosine triphosphate hydrolysis by actomyosin. Biochemistry 10, 4617-24. 
Mandal, L., Banerjee, U. and Hartenstein, V. (2004). Evidence for a fruit fly hemangioblast and similarities between lymph-gland hematopoiesis in fruit fly and mammal aorta-gonadalmesonephros mesoderm. Nat. Genet. 36, 1019-23.

Manseau, L. J. and Schüpbach, T. (1989). cappuccino and spire: two unique maternal-effect loci required for both the anteroposterior and dorsoventral patterns of the Drosophila embryo. Genes Dev. 3, 1437-52.

Mardahl-Dumesnil, M. and Fowler, V. M. (2001). Thin filaments elongate from their pointed ends during myofibril assembly in Drosophila indirect flight muscle. J. Cell Biol. 155, 1043-53.

Matusek, T., Djiane, A., Jankovics, F., Brunner, D., Mlodzik, M. and Mihály, J. (2006). The Drosophila formin DAAM regulates the tracheal cuticle pattern through organizing the actin cytoskeleton. Development 133, 957-66.

Matusek, T., Gombos, R., Szécsényi, A., Sánchez-Soriano, N., Czibula, A., Pataki, C., Gedai, A., Prokop, A., Raskó, I. and Mihály, J. (2008). Formin proteins of the DAAM subfamily play a role during axon growth. J. Neurosci. 28, 13310-9.

Maughan, D. W. and Vigoreaux, J. O. (1999). An Integrated View of Insect Flight Muscle: Genes, Motor Molecules, and Motion. News Physiol. Sci. 14, 87-92.

McKeown, C. R., Nowak, R. B., Moyer, J., Sussman, M. A. and Fowler, V. M. (2008). Tropomodulin1 is required in the heart but not the yolk sac for mouse embryonic development. Circ. Res. 103, 1241-8.

Michelot, A., Guérin, C., Huang, S., Ingouff, M., Richard, S., Rodiuc, N., Staiger, C. J. and Blanchoin, L. (2005). The formin homology 1 domain modulates the actin nucleation and bundling activity of Arabidopsis FORMIN1. Plant Cell 17, 2296-313.

Miller, G., Musa, H., Gautel, M. and Peckham, M. (2003). A targeted deletion of the Cterminal end of titin, including the titin kinase domain, impairs myofibrillogenesis. J. Cell Sci. 116, 4811-9.

Mi-Mi, L., Votra, S., Kemphues, K., Bretscher, A. and Pruyne, D. (2012). Z-line formins promote contractile lattice growth and maintenance in striated muscles of C. elegans. J. Cell Biol. 198, 87-102.

Moerman, D. G. and Williams, B. D. (2006). Sarcomere assembly in C. elegans muscle. WormBook 1-16.

Molina, M. R. and Cripps, R. M. (2001). Ostia, the inflow tracts of the Drosophila heart, develop from a genetically distinct subset of cardial cells. Mech. Dev. 109, 51-9. 
Molnár, I., Migh E, Szikora S, Kalmár T, Végh AG, Deák F, Barkó S, Bugyi B, Orfanos Z, Kovács J, Juhász G, Váró G, Nyitrai M, Sparrow J and Mihály J. (2014). DAAM is required for thin filament formation and sarcomerogenesis during muscle development in Drosophila. PLoS Genetics. 10(2):e1004166.

Moseley, J. B. and Goode, B. L. (2005). Differential activities and regulation of Saccharomyces cerevisiae formin proteins Bnil and Bnr1 by Bud6. J. Biol. Chem. 280, 28023-33.

Moseley, J. B., Sagot, I., Manning, A. L., Xu, Y., Eck, M. J., Pellman, D. and Goode, B. L. (2004). A conserved mechanism for Bnil- and mDial-induced actin assembly and dual regulation of Bni1 by Bud6 and profilin. Mol. Biol. Cell 15, 896-907.

Nakaya, M., Habas, R., Biris, K., Dunty, W. C., Kato, Y., He, X. and Yamaguchi, T. P. (2004). Identification and comparative expression analyses of Daam genes in mouse and Xenopus. Gene Expr. Patterns 5, 97-105.

Nelson, K. S., Khan, Z., Molnár, I., Mihály, J., Kaschube, M. and Beitel, G. J. (2012). Drosophila Src regulates anisotropic apical surface growth to control epithelial tube size. Nat. Cell Biol. 14, 518-25.

Niederman, R. and Pollard, T. D. (1975). Human platelet myosin. II. In vitro assembly and structure of myosin filaments. J. Cell Biol. 67, 72-92.

Nongthomba, U., Clark, S., Cummins, M., Ansari, M., Stark, M. and Sparrow, J. C. (2004). Troponin I is required for myofibrillogenesis and sarcomere formation in Drosophila flight muscle. J. Cell Sci. 117, 1795-805.

O'Donnell, P. T. and Bernstein, S. I. (1988). Molecular and ultrastructural defects in a Drosophila myosin heavy chain mutant: differential effects on muscle function produced by similar thick filament abnormalities. J. Cell Biol. 107, 2601-12.

Okamoto, H., Hiromi, Y., Ishikawa, E., Yamada, T., Isoda, K., Maekawa, H. and Hotta, Y. (1986). Molecular characterization of mutant actin genes which induce heat-shock proteins in Drosophila flight muscles. EMBO J. 5, 589-96.

Otomo, T., Tomchick, D. R., Otomo, C., Panchal, S. C., Machius, M. and Rosen, M. K. (2005). Structural basis of actin filament nucleation and processive capping by a formin homology 2 domain. Nature 433, 488-94.

Pardo, J. V, Siliciano, J. D. and Craig, S. W. (1983). A vinculin-containing cortical lattice in skeletal muscle: transverse lattice elements ("costameres") mark sites of attachment between myofibrils and sarcolemma. Proc. Natl. Acad. Sci. U. S. A. 80, 1008-12.

Paul, A. S. and Pollard, T. D. (2009). Review of the mechanism of processive actin filament elongation by formins. Cell Motil. Cytoskeleton 66, 606-17. 
Pollard, T. D. (2007). Regulation of actin filament assembly by Arp2/3 complex and formins. Annu. Rev. Biophys. Biomol. Struct. 36, 451-77.

Pring, M., Evangelista, M., Boone, C., Yang, C. and Zigmond, S. H. (2003). Mechanism of formin-induced nucleation of actin filaments. Biochemistry 42, 486-96.

Pruyne, D., Evangelista, M., Yang, C., Bi, E., Zigmond, S., Bretscher, A. and Boone, C. (2002). Role of formins in actin assembly: nucleation and barbed-end association. Science 297, 612-5.

Quach, N. L. and Rando, T. A. (2006). Focal adhesion kinase is essential for costamerogenesis in cultured skeletal muscle cells. Dev. Biol. 293, 38-52.

Qualmann, B. and Kessels, M. M. (2009). New players in actin polymerization--WH2-domaincontaining actin nucleators. Trends Cell Biol. 19, 276-85.

Quinlan, M. E., Heuser, J. E., Kerkhoff, E. and Mullins, R. D. (2005). Drosophila Spire is an actin nucleation factor. Nature 433, 382-8.

Quinlan, M. E., Hilgert, S., Bedrossian, A., Mullins, R. D. and Kerkhoff, E. (2007). Regulatory interactions between two actin nucleators, Spire and Cappuccino. J. Cell Biol. 179, 117-28.

Randall, D., Burggren, W. and Kathleen, F. (2002). Eckert Animal Physiology: Mechanisms and Adaptations, Fifth edition.

Reedy, M. C. and Beall, C. (1993). Ultrastructure of developing flight muscle in Drosophila. I. Assembly of myofibrils. Dev. Biol. 160, 443-65.

Rhee, D., Sanger, J. M. and Sanger, J. W. (1994). The premyofibril: evidence for its role in myofibrillogenesis. Cell Motil. Cytoskeleton 28, 1-24.

Rizki, T. M. and Rizki, R. M. (1978). Larval adipose tissue of homoeotic bithorax mutants of Drosophila. Dev. Biol. 65, 476-82.

Rosales-Nieves, A. E., Johndrow, J. E., Keller, L. C., Magie, C. R., Pinto-Santini, D. M. and Parkhurst, S. M. (2006). Coordination of microtubule and microfilament dynamics by Drosophila Rho1, Spire and Cappuccino. Nat. Cell Biol. 8, 367-76.

Rose, R., Weyand, M., Lammers, M., Ishizaki, T., Ahmadian, M. R. and Wittinghofer, A. (2005). Structural and mechanistic insights into the interaction between Rho and mammalian Dia. Nature 435, 513-8.

Rosser, B. W., Wick, M., Waldbillig, D. M., Wright, D. J., Farrar, C. M. and Bandman, E. (1998). Expression of myosin heavy chain isoforms during development of domestic pigeon pectoralis muscle. Int. J. Dev. Biol. 42, 653-61. 
Röper, K., Mao, Y. and Brown, N. H. (2005). Contribution of sequence variation in Drosophila actins to their incorporation into actin-based structures in vivo. J. Cell Sci. 118, 3937-48.

Rui, Y., Bai, J. and Perrimon, N. (2010). Sarcomere formation occurs by the assembly of multiple latent protein complexes. PLoS Genet. 6, e1001208.

Sagot, I., Rodal, A. A., Moseley, J., Goode, B. L. and Pellman, D. (2002). An actin nucleation mechanism mediated by Bnil and profilin. Nat. Cell Biol. 4, 626-31.

Sanger, J. W., Wang, J., Fan, Y., White, J. and Sanger, J. M. (2010). Assembly and dynamics of myofibrils. J. Biomed. Biotechnol. 2010, 858606.

Schnorrer, F. and Dickson, B. J. (2004). Muscle building; mechanisms of myotube guidance and attachment site selection. Dev. Cell 7, 9-20.

Scholey, J. M., Taylor, K. A. and Kendrick-Jones, J. (1980). Regulation of non-muscle myosin assembly by calmodulin-dependent light chain kinase. Nature 287, $233-5$.

Shimada, A., Nyitrai, M., Vetter, I. R., Kühlmann, D., Bugyi, B., Narumiya, S., Geeves, M. A. and Wittinghofer, A. (2004). The core FH2 domain of diaphanous-related formins is an elongated actin binding protein that inhibits polymerization. Mol. Cell 13, 511-22.

Skau, C. T., Neidt, E. M. and Kovar, D. R. (2009). Role of tropomyosin in formin-mediated contractile ring assembly in fission yeast. Mol. Biol. Cell 20, 2160-73.

Skwarek-Maruszewska, A., Boczkowska, M., Zajac, A. L., Kremneva, E., Svitkina, T., Dominguez, R. and Lappalainen, P. (2010). Different localizations and cellular behaviors of leiomodin and tropomodulin in mature cardiomyocyte sarcomeres. Mol. Biol. Cell 21, $3352-61$.

Sparrow, J. C. and Schöck, F. (2009). The initial steps of myofibril assembly: integrins pave the way. Nat. Rev. Mol. Cell Biol. 10, 293-8.

Srikakulam, R. and Winkelmann, D. A. (2004). Chaperone-mediated folding and assembly of myosin in striated muscle. J. Cell Sci. 117, 641-52.

Stevenson, T. O., Mercer, K. B., Cox, E. A., Szewczyk, N. J., Conley, C. A., Hardin, J. D. and Benian, G. M. (2007). unc-94 encodes a tropomodulin in Caenorhabditis elegans. $J$. Mol. Biol. 374, 936-50.

Sussman, M. A., Baqué, S., Uhm, C. S., Daniels, M. P., Price, R. L., Simpson, D., Terracio, L. and Kedes, L. (1998). Altered expression of tropomodulin in cardiomyocytes disrupts the sarcomeric structure of myofibrils. Circ. Res. 82, 94-105. 
Swank, D. M., Braddock, J., Brown, W., Lesage, H., Bernstein, S. I. and Maughan, D. W. (2006). An alternative domain near the ATP binding pocket of Drosophila myosin affects muscle fiber kinetics. Biophys. J. 90, 2427-35.

Taniguchi, K., Takeya, R., Suetsugu, S., Kan-O, M., Narusawa, M., Shiose, A., Tominaga, R. and Sumimoto, H. (2009). Mammalian formin fhod3 regulates actin assembly and sarcomere organization in striated muscles. J. Biol. Chem. 284, 29873-81.

Tetzlaff, M. T., Jäckle, H. and Pankratz, M. J. (1996). Lack of Drosophila cytoskeletal tropomyosin affects head morphogenesis and the accumulation of oskar mRNA required for germ cell formation. EMBO J. 15, 1247-54.

Thisse, B., Heyer, V., Lux, A., Alunni, V., Degrave, A., Seiliez, I., Kirchner, J., Parkhill, J.P. and Thisse, C. (2004). Spatial and temporal expression of the zebrafish genome by large-scale in situ hybridization screening. Methods Cell Biol. 77, 505-19.

Tokuyasu, K. T. (1989). Immunocytochemical studies of cardiac myofibrillogenesis in early chick embryos. III. Generation of fasciae adherentes and costameres. J. Cell Biol. 108, 4353.

Trombitás, K., Greaser, M., French, G. and Granzier, H. (1998). PEVK extension of human soleus muscle titin revealed by immunolabeling with the anti-titin antibody 9D10. J. Struct. Biol. 122, 188-96.

Tskhovrebova, L. and Trinick, J. (2003). Titin: properties and family relationships. Nat. Rev. Mol. Cell Biol. 4, 679-89.

Vaillant, D. C., Copeland, S. J., Davis, C., Thurston, S. F., Abdennur, N. and Copeland, J. W. (2008). Interaction of the N- and C-terminal autoregulatory domains of FRL2 does not inhibit FRL2 activity. J. Biol. Chem. 283, 33750-62.

Vigoreaux, J. O. (2001). Genetics of the Drosophila flight muscle myofibril: a window into the biology of complex systems. Bioessays 23, 1047-63.

Vinckier, A. and Semenza, G. (1998). Measuring elasticity of biological materials by atomic force microscopy. FEBS Lett. 430, 12-6.

Vogel, B., Meder, B., Just, S., Laufer, C., Berger, I., Weber, S., Katus, H. A. and Rottbauer, W. (2009). In-vivo characterization of human dilated cardiomyopathy genes in zebrafish. Biochem. Biophys. Res. Commun. 390, 516-22.

Wallar, B. J. and Alberts, A. S. (2003). The formins: active scaffolds that remodel the cytoskeleton. Trends Cell Biol. 13, 435-46. 
Wang, S. M., Greaser, M. L., Schultz, E., Bulinski, J. C., Lin, J. J. and Lessard, J. L. (1988). Studies on cardiac myofibrillogenesis with antibodies to titin, actin, tropomyosin, and myosin. J. Cell Biol. 107, 1075-83.

Wawro, B., Greenfield, N. J., Wear, M. A., Cooper, J. A., Higgs, H. N. and HitchcockDeGregori, S. E. (2007). Tropomyosin regulates elongation by formin at the fast-growing end of the actin filament. Biochemistry 46, 8146-55.

Weitkunat, M., Kaya-Çopur, A., Grill, S. W. and Schnorrer, F. (2014). Tension and forceresistant attachment are essential for myofibrillogenesis in Drosophila flight muscle. Curr. Biol. 24, 705-16.

Welsh, I. C., Thomsen, M., Gludish, D. W., Alfonso-Parra, C., Bai, Y., Martin, J. F. and Kurpios, N. A. (2013). Integration of left-right Pitx2 transcription and Wnt signaling drives asymmetric gut morphogenesis via Daam2. Dev. Cell 26, 629-44.

Wen, Y., Eng, C. H., Schmoranzer, J., Cabrera-Poch, N., Morris, E. J. S., Chen, M., Wallar, B. J., Alberts, A. S. and Gundersen, G. G. (2004). EB1 and APC bind to mDia to stabilize microtubules downstream of Rho and promote cell migration. Nat. Cell Biol. 6, 820-30.

Willis, M. S., Schisler, J. C., Portbury, A. L. and Patterson, C. (2009). Build it up-Tear it down: protein quality control in the cardiac sarcomere. Cardiovasc. Res. 81, 439-48.

Witt, C. C., Burkart, C., Labeit, D., McNabb, M., Wu, Y., Granzier, H. and Labeit, S. (2006). Nebulin regulates thin filament length, contractility, and Z-disk structure in vivo. EMBO J. 25, 3843-55.

Woychik, R. P., Maas, R. L., Zeller, R., Vogt, T. F. and Leder, P. (1990). "Formins": proteins deduced from the alternative transcripts of the limb deformity gene. Nature 346, 850-3.

Xu, Y., Moseley, J. B., Sagot, I., Poy, F., Pellman, D., Goode, B. L. and Eck, M. J. (2004). Crystal structures of a Formin Homology-2 domain reveal a tethered dimer architecture. Cell 116, 711-23.

Yaffe, D. and Saxel, O. (1977). Serial passaging and differentiation of myogenic cells isolated from dystrophic mouse muscle. Nature 270, 725-7.

Yamashiro, S., Cox, E. A., Baillie, D. L., Hardin, J. D. and Ono, S. (2008). Sarcomeric actin organization is synergistically promoted by tropomodulin, ADF/cofilin, AIP1 and profilin in C. elegans. J. Cell Sci. 121, 3867-77.

Yamashita, M., Higashi, T., Suetsugu, S., Sato, Y., Ikeda, T., Shirakawa, R., Kita, T., Takenawa, T., Horiuchi, H., Fukai, S., et al. (2007). Crystal structure of human DAAM1 formin homology 2 domain. Genes Cells 12, 1255-65. 
Yi, K., Guo, C., Chen, D., Zhao, B., Yang, B. and Ren, H. (2005). Cloning and functional characterization of a formin-like protein (AtFH8) from Arabidopsis. Plant Physiol. 138, 1071-82.

Yonetani, A., Lustig, R. J., Moseley, J. B., Takeda, T., Goode, B. L. and Chang, F. (2008). Regulation and targeting of the fission yeast formin cdc12p in cytokinesis. Mol. Biol. Cell 19, 2208-19.

Zuniga, A., Michos, O., Spitz, F., Haramis, A.-P. G., Panman, L., Galli, A., Vintersten, K., Klasen, C., Mansfield, W., Kuc, S., et al. (2004). Mouse limb deformity mutations disrupt a global control region within the large regulatory landscape required for Gremlin expression. Genes Dev. 18, 1553-64. 